\title{
Review
}

\section{Dissolved effluent organic matter: Characteristics and potential implications in wastewater treatment and reuse applications}

\author{
I. Michael-Kordatou ${ }^{a}$, C. Michael ${ }^{a}$, X. Duan ${ }^{a, b}$, X. He ${ }^{a, b}$, \\ D.D. Dionysiou ${ }^{a, b}$, M.A. Mills ${ }^{c}$, D. Fatta-Kassinos ${ }^{a, *}$
}

a Department of Civil and Environmental Engineering and Nireas-International Water Research Centre, School of Engineering, University of Cyprus, P.O. Box 20537, 1678 Nicosia, Cyprus

${ }^{\mathrm{b}}$ Environmental Engineering and Science Program, University of Cincinnati, Cincinnati, OH 45221-0071, USA

c US EPA, Office of Research and Development, 26 W, Martin Luther King Drive, Cincinnati, OH 45268, USA

\section{A R T I C L E I N F O}

Article history:

Received 27 August 2014

Received in revised form

19 February 2015

Accepted 16 March 2015

Available online 24 March 2015

Keywords:

Biological effects

Dissolved effluent organic matter

\begin{abstract}
A B S T R A C T
Wastewater reuse is currently considered globally as the most critical element of sustainable water management. The dissolved effluent organic matter $\left(\mathrm{dE}_{\mathrm{f}} \mathrm{OM}\right)$ present in biologically treated urban wastewater, consists of a heterogeneous mixture of refractory organic compounds with diverse structures and varying origin, including dissolved natural organic matter, soluble microbial products, endocrine disrupting compounds, pharmaceuticals and personal care products residues, disinfection by-products, metabolites/transformation products and others, which can reach the aquatic environment through discharge and reuse applications. $\mathrm{dE}_{\mathrm{f}} \mathrm{OM}$ constitutes the major fraction of the effluent organic matter $\left(E_{\mathrm{f}} \mathrm{OM}\right)$ and due to its chemical complexity, it is necessary to utilize a battery of complementary techniques to adequately describe its
\end{abstract}

\footnotetext{
Abbreviations: ABR, anaerobic baffled reactor; AC, activated carbon; AER, anion-exchange resin; AOPs, advanced chemical oxidation processes; ARB\&ARG, antibiotic-resistant bacteria and genes; BAPs, biomass-associated products; BLM, biotic ligand model; BOD, biological oxygen demand; CAS, conventional activated sludge; CECs, contaminants of emerging concern; COD, chemical oxygen demand; DBPs, disinfection by-products; $\mathrm{dE}_{\mathrm{f}} \mathrm{OM}$, dissolved effluent organic matter; $\mathrm{DOC}$, dissolved organic carbon; DON, dissolved organic nitrogen; DPR, direct potable use; EC, European Commission; EDCs, endocrine disrupting chemicals; $\mathrm{E}_{\mathrm{f}} \mathrm{OM}$, effluent organic matter; EQS, environmental quality standards; ESI-FT-ICR-MS, electrospray ionization Fourier transform ion cyclotron resonance mass spectrometry; FI, fluorescence index; FTIR, Fourier-transform infrared spectrometry; FT-MS, Orbitrap Fourier transform mass spectrometry; GAC, granular activated carbon; GC, gas chromatography; HAAs, haloacetic acids; HRT, Hydraulic retention time; HPSEC, high performance size-exclusion chromatography; IPR, indirect potable reuse; LEDs, light emitting diodes; LMM, low molar mass; MBR, membrane bioreactor; MF, microfiltration; MIEX ${ }^{\circledR}$, magnetic ion-exchange resin; MS, mass spectroscopy; MW, molecular weight; MWCO, molecular weight cut-off; MWD, molecular weight distribution; NF, nanofiltration; NDMA, N-nitrosodimethylamine; NMR, nuclear magnetic resonance; NOM, natural organic matter; PAC, powdered activated carbon; $\mathrm{pE}_{\mathrm{f}} \mathrm{OM}$, particulate effluent organic matter; PPCPs, pharmaceuticals and personal care products residues; RO, reverse osmosis; SBR, sequencing batch reactor; SEC, size-exclusion chromatography; SMPs, soluble microbial products; SRT, solid retention time; SUVA, specific UV absorbance at $254 \mathrm{~nm}$; THMs, trihalomethanes; TSS, total suspended solids; UAPs, utilization-associated products; UF, ultrafiltration; USEPA, United States Environmental Protection Agency; $\mathrm{UV}_{254}$, ultraviolet absorbance at $254 \mathrm{~nm}$; UV/Vis, ultraviolet/visible spectrometry; WWTPs, wastewater treatment plants; WET, whole effluent toxicity; WHO, World Health Organization.

* Corresponding author. Tel.: +357 22893515; fax: +357 22895365.
}

E-mail address: dfatta@ucy.ac.cy (D. Fatta-Kassinos).

http://dx.doi.org/10.1016/j.watres.2015.03.011

0043-1354/@ 2015 Elsevier Ltd. All rights reserved. 
Effluent organic matter

Metal complexation

Toxicity

Wastewater treatment and reuse structural and functional character. $\mathrm{dE}_{\mathrm{f}} \mathrm{OM}$ has been shown to exhibit contrasting effects towards various aquatic organisms. It decreases metal uptake, thus potentially reducing their bioavailability to exposed organisms. On the other hand, $\mathrm{dE}_{\mathrm{f}} \mathrm{OM}$ can be adsorbed on cell membranes inducing toxic effects. This review paper evaluates the performance of various advanced treatment processes (i.e., membrane filtration and separation processes, activated carbon adsorption, ion-exchange resin process, and advanced chemical oxidation processes) in removing $\mathrm{dE}_{\mathrm{f}} \mathrm{OM}$ from wastewater effluents. In general, the literature findings reveal that $\mathrm{dE}_{\mathrm{f}} \mathrm{OM}$ removal by advanced treatment processes depends on the type and the amount of organic compounds present in the aqueous matrix, as well as the operational parameters and the removal mechanisms taking place during the application of each treatment technology.

๑) 2015 Elsevier Ltd. All rights reserved.

\section{Contents}

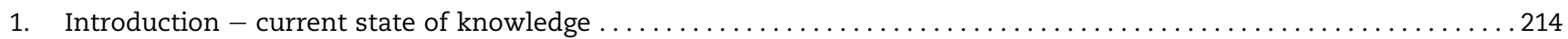

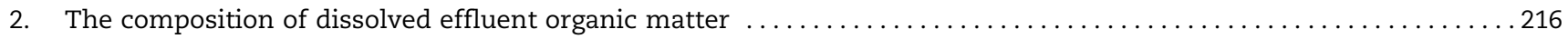

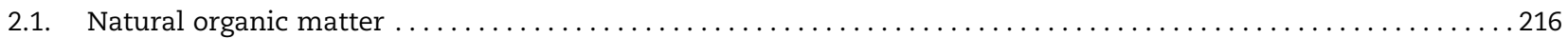

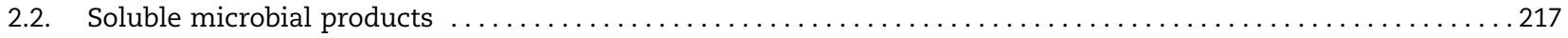

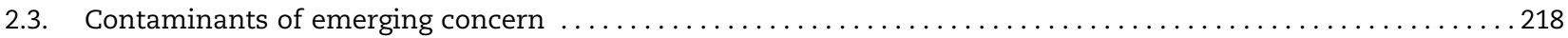

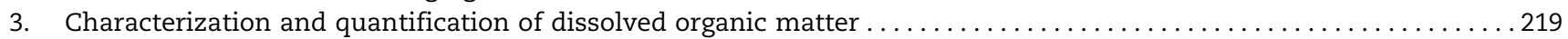

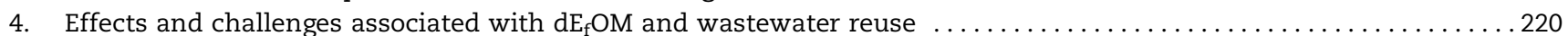

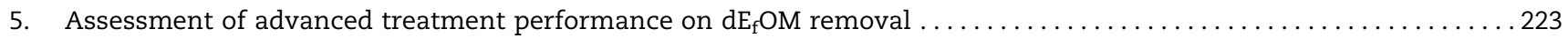

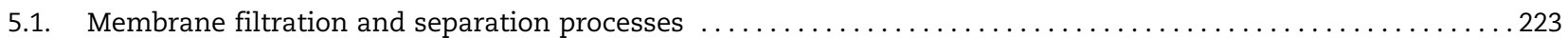

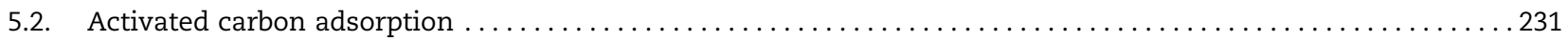

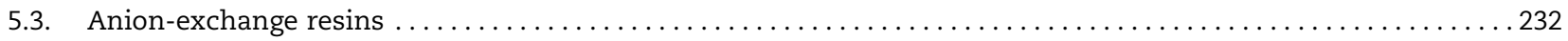

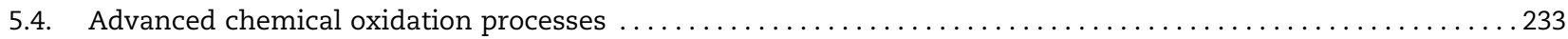

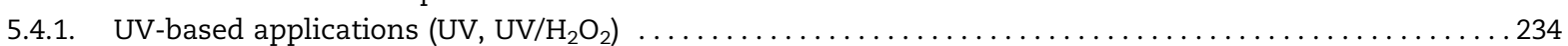

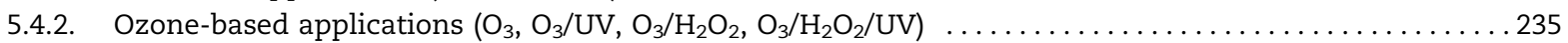

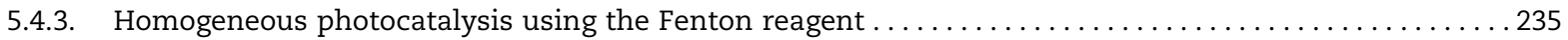

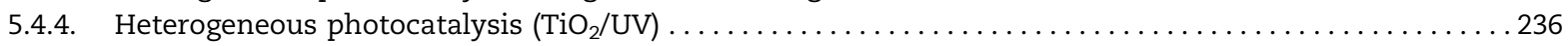

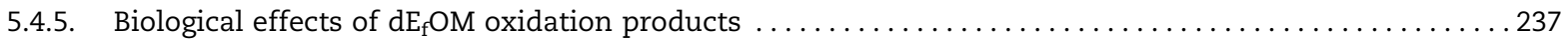

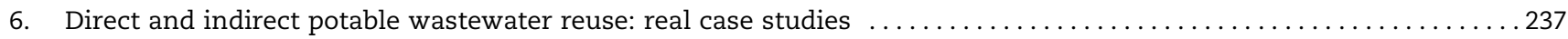

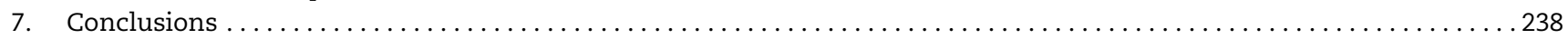

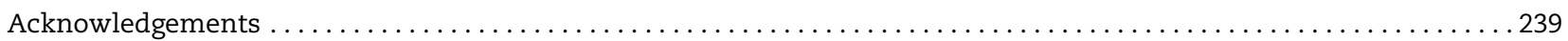

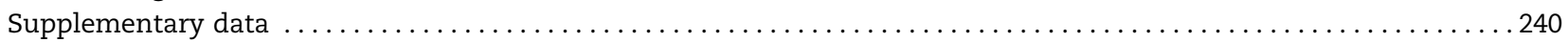

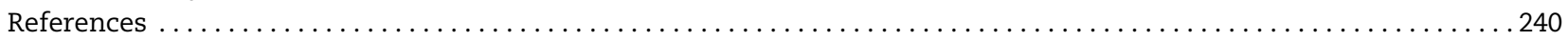

\section{Introduction - current state of knowledge}

Reuse of urban wastewater is considered as an important component of sustainable wastewater management practices worldwide, mainly for non-potable applications. Reclaimed wastewater is widely reused for surface and groundwater replenishment purposes, while agricultural and landscape irrigation (e.g., golf camp irrigation) in water-scarce regions such as Cyprus, France, Italy, Israel, Jordan, Lebanon, Malta, Spain, etc is widely implemented (Bdour et al., 2009; Muñoz et al., 2009; Pedrero et al., 2010; Kalavrouziotis et al., 2013; Becerra-Castro et al., 2015). Water scarcity, foreseen to aggravate in Mediterranean countries, led to the utilization of reclaimed wastewater, for the irrigation of forage and cereals, fruit trees and in some cases vegetables, depending on the discharge standards stated in the national legislation. According to Bixio et al. (2008), four non-potable uses of reclaimed wastewater are identified worldwide (mostly in Australia, Europe, Japan, and US): (i) agricultural irrigation, (ii) industry, (iii) urban, recreational and environmental uses (including aquifer recharge), and (iv) combinations of the above.

A distinction between 'indirect' and 'direct' potable reuse applications was proposed by USEPA (2004) and Gerrity et al. (2013), depending on whether the reclaimed wastewater is used directly or mixed with other sources. Indirect potable reuse (IPR) occurs through the augmentation of drinking water supplies with urban wastewater treated to a level suitable for IPR followed by an environmental buffer (e.g., rivers, dams, 
aquifers, etc.). In this case, urban wastewater passes through a series of treatment steps that encompasses membrane filtration and separation processes (e.g., microfiltration [MF], ultrafiltration [UF] and reverse osmosis [RO]), followed by an advanced chemical oxidation process (e.g., UV, ozone) (Rodriguez et al., 2009). A noticeable example of IPR was observed during the severe drought in Barcelona during 2008, when the water authorities in the region considered augmenting drinking water supplies with reclaimed wastewater, through the discharge of the latter into a river (López-Serna et al., 2012). IPR or even unplanned potable use of reclaimed wastewater exists in many countries (Bixio et al., 2006; Bdour et al., 2009), where the latter is discharged into groundwater to hold back saline intrusion in coastal aquifers. IPR has generally included some type of environmental buffer, but conditions in certain areas have created an urgent need for more direct alternatives. Direct potable reuse (DPR) examples (i.e., introduction of purified water derived from urban wastewater after extensive treatment and monitoring directly into a municipal water supply system, Leverenz et al., 2011) have also been reported (Pisani and Menge, 2013; Etchepare and van der Hoek, 2014). A representative example of DPR is the case of Windhoek (Namibia), where treated wastewater has been blended with drinking water for more than 40 years, based on the multiple treatment barriers concept (i.e., pre-ozonation, enhanced coagulation/dissolved air flotation/rapid sand filtration, and subsequent ozone, biological activated carbon/granular activated carbon) to reduce associated risks and improve the water quality.

The practice of wastewater reuse, in particular for irrigation, is accompanied by a number of benefits relating to the enhancement of water balances and soil enrichment by the nutrients existing in the treated effluents (World Health Organization-WHO, 2006; Candela et al., 2007; Murray and Ray, 2010). However, there is general lack of knowledge regarding the remaining effluent organic matter $\left(\mathrm{E}_{\mathrm{f}} \mathrm{OM}\right)$ in the urban wastewater after conventional treatment, and the potential implications following its discharge in the environment.

The generic term $\mathrm{E}_{\mathrm{f}} \mathrm{OM}$ is used herein to denote a variety of recalcitrant organic compounds present in the biologically treated urban wastewater for which chemical structure cannot be uniquely identified, but can be grouped according to their functional moieties (Abbt-Braun et al., 2004). The organic composition of the $\mathrm{E}_{\mathrm{f}} \mathrm{OM}$ in reclaimed wastewater is a reflection of the origin of the raw water before becoming wastewater and of the domestic, industrial, and agricultural activities contributing to the sewage influent, while it also depends on the wastewater treatment processes applied and their operating conditions. The scientific community has experienced difficulties in providing a unified definition of $\mathrm{E}_{\mathrm{f}} \mathrm{OM}$ due to its high structural and functional complexity. During the last decades, substantial effort has been directed towards the characterization of the dissolved effluent organic matter $\left(\mathrm{dE}_{\mathrm{f}} \mathrm{OM}\right)$, which is functionally defined as the fraction of the $\mathrm{E}_{\mathrm{f}} \mathrm{OM}$ that passes through a $0.45 \mu \mathrm{m}$ membrane filter, and generally represents the major fraction (>90\%) of the $\mathrm{E}_{\mathrm{f}} \mathrm{OM}$ (Thurman, 1985). According to Drewes and Fox (2000), $\mathrm{dE}_{\mathrm{f}} \mathrm{OM}$ comprises dissolved natural organic matter (NOM) deriving from drinking water sources, soluble microbial products (SMPs) originating from the activated sludge treatment, and trace organic compounds of industrial and residential origin along with their transformation products resulting during treatment. Dissolved organic carbon (DOC) is widely used as a surrogate parameter for the quantification of $\mathrm{dE}_{\mathrm{f}} \mathrm{OM}$. However, this parameter provides a general assessment of $\mathrm{dE}_{\mathrm{f}} \mathrm{OM}$ and does not elucidate its structural characteristics. Because of the immense structural complexity of $\mathrm{dE}_{\mathrm{f}} \mathrm{OM}$, a variety of analytical techniques have been utilized

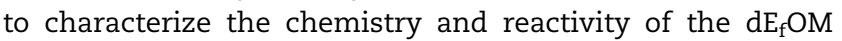
components. These include: physicochemical analysis (e.g., elemental analysis, acid/base titration), spectroscopic methods (e.g., ultraviolet/visible spectrometry [UV/Vis], Fourier-transform infrared spectroscopy [FTIR], nuclear magnetic resonance [NMR], fluorescence spectroscopy), chromatographic methods (e.g., gel chromatography or high performance size-exclusion chromatography [HPSEC]), thermal degradation methods (e.g., pyrolysis in combination with liquid or gas chromatography coupled with mass spectrometry [LC/MS or GC/MS]), and other fractionation techniques (Abbt-Braun et al., 2004; Uyguner-Demirel and Bekbolet, 2011).

Reclaimed wastewater is being widely used, but as highlighted in Fatta-Kassinos et al. (2011a), a number of unanswered questions are still related to this practice, especially with regard to the presence of $d_{\mathrm{f}} \mathrm{OM}$ in the treated effluents. For example, $d_{\mathrm{f}} \mathrm{OM}$ is considered to be a precursor for disinfection by-products (DBPs) during wastewater chlorination (Crebelli et al., 2005; Krasner et al., 2009), which have been linked to cancer and reproductive defects (United States Environmental Protection Agency-USEPA, 2006). It is also correlated to other unwanted water quality-related issues, since it increases the transport and distribution of inorganic and organic microcontaminants due to its metal complexation capacity and interactive properties with organic compounds (Shon et al., 2006a). In addition, there are limited and conflicting reports with respect to the toxicity of $d_{\mathrm{f}} \mathrm{OM}$ on aquatic microorganisms. Direct adverse interactions of dissolved organic matter present in natural water with aquatic organisms have been observed due to its capacity to penetrate into the cell membranes (Campbell et al., 1997; Vigneault et al., 2000; Wood et al., 2003; Glover et al., 2005; Meinelt et al., 2007), while $\mathrm{dE}_{\mathrm{f}} \mathrm{OM}$ was found to induce toxic effects (Vasquez and Fatta-Kassinos, 2013). On the other hand, Pernet-Coudrier et al. (2008) reported that $\mathrm{dE}_{\mathrm{f}} \mathrm{OM}$ may interfere with the fate and transport of many compounds (i.e., metals, microcontaminants), potentially by altering/reducing their bioavailability and toxicity to aquatic microorganisms. $\mathrm{dE}_{\mathrm{f}} \mathrm{OM}$ also constitutes a key design and operational parameter in wastewater treatment processes. For example, it is responsible for membrane fouling (Jarusutthirak et al., 2002), acts as substrate for bacterial growth in distribution systems, and interferes with the removal of other contaminants (Joseph et al., 2012).

As a mixture of heterogeneous soluble organic compounds, $\mathrm{dE}_{\mathrm{f}} \mathrm{OM}$ is persistent and very difficult to treat cost-effectively in wastewater. Recently, the application of advanced treatment processes has gained significant attention for removing $\mathrm{dE}_{\mathrm{f}} \mathrm{OM}$. Detailed investigations on the utilization of membrane filtration, activated carbon adsorption, 
anion-exchange resin treatment, and advanced chemical oxidation processes have been reported (Shon et al., 2007; Gur-Reznik et al., 2008; Filloux et al., 2012b; Gonzales et al., 2012; Audenaert et al., 2013; Rodríguez-Chueca et al., 2014). The evaluation of the literature findings emphasizes that the removal of $\mathrm{dE}_{\mathrm{f}} \mathrm{OM}$ and its sub-constituents are influenced by the process mechanisms and operational parameters, while its removal is study-specific depending on the diverse physicochemical characteristics of the matrix, such as the kind and the amount of organic matter (Shon et al., 2006a).

This review paper focuses on the chemical structure of $\mathrm{dE}_{\mathrm{f}} \mathrm{OM}$ and its related fractions, and it provides an overview of the analytical techniques applied for its characterization. The current knowledge on the potential biological effects of $\mathrm{dE}_{\mathrm{f}} \mathrm{OM}$ is also presented. Thereafter, an overview on the evaluation of the performance of various advanced treatment technologies in removing $\mathrm{dE}_{\mathrm{f}} \mathrm{OM}$ from wastewater effluents, together with recent relevant literature, is provided. This review paper highlights relevant knowledge gaps that relate to the future research directions required on the behaviour and potential biological effects of $\mathrm{dE}_{\mathrm{f}} \mathrm{OM}$, once released in the environment.

According to the authors' knowledge, this review paper constitutes the first integrated approach regarding $d_{\mathrm{f}} \mathrm{OM}$ constituents, its biological potency towards various species and its removal through the application of different advanced treatment technologies. This is of special interest in the context of sustainable wastewater reuse strategies, since the presence of $\mathrm{dE}_{\mathrm{f}} \mathrm{OM}$ not only affects the current discharge standards of the treated wastewater effluent, but also becomes a primary constraint to safe wastewater reuse.

\section{The composition of dissolved effluent organic matter}

$\mathrm{E}_{\mathrm{f}} \mathrm{OM}$ consists of both particulate and dissolved organic compounds. Filtration through a $0.45 \mu \mathrm{m}$ filter has been established as the standard procedure for separating dissolved and particulate components (Danielsson, 1982). It is generally accepted that particles under $0.45 \mu \mathrm{m}$ are classified as dissolved (i.e., $\mathrm{dE}_{\mathrm{f}} \mathrm{OM}$ ), while particles above that limit are classified as colloidal or particulate effluent organic matter $\left(\mathrm{pE}_{\mathrm{f}} \mathrm{OM}\right)$. Within $\mathrm{E}_{\mathrm{f}} \mathrm{OM}$, cellulose fibers comprise a major constituent of $\mathrm{pE}_{\mathrm{f}} \mathrm{OM}$ due to their incomplete conversion during the activated sludge treatment (Ruiken et al., 2013). Other $\mathrm{pE}_{\mathrm{f}} \mathrm{OM}$ constituents include algae, protozoa, bacterial flocs and single cells, microbial waste products, and other miscellaneous debris (Levine et al., 1985). $\mathrm{dE}_{\mathrm{f}} \mathrm{OM}$ is generally the most studied fraction of $\mathrm{E}_{\mathrm{f}} \mathrm{OM}$, though limited research has been reported (Drewes and Croué, 2002; Jin et al., 2011).

The $\mathrm{dE}_{\mathrm{f}} \mathrm{OM}$ present in the biologically treated wastewater consists of dissolved natural organic matter (NOM) that derives from drinking water sources, soluble microbial products (SMPs) that are formed during the biological wastewater treatment (i.e., activated sludge), trace organic compounds (microcontaminants) produced during domestic and/or industrial use (e.g., endocrine disrupting chemicals [EDCs], pharmaceuticals and personal care products residues [PPCPs], etc), disinfection by-products (DBPs) and transformation products resulting from the various biotic and abiotic processes that can take place during treatment (Levine et al., 1985; Drewes et al., 2003). dE $\mathrm{f}_{\mathrm{f}} \mathrm{OM}$ includes mainly cell fragments (less than $0.2 \mu \mathrm{m}$ diameter size) and macromolecules (e.g., proteins, polysaccharides, etc.) (Shon et al., 2006a). The characteristics and the content of $\mathrm{dE}_{\mathrm{f}} \mathrm{OM}$ are highly dependent on the sources of wastewater, the processes of wastewater treatment and their operating conditions (Jin et al., 2011). Fig. 1 illustrates the main origins of influent urban wastewater along with the main components of the $\mathrm{dE}_{\mathrm{f}} \mathrm{OM}$ that can potentially result during biological wastewater treatment.

\subsection{Natural organic matter}

Natural organic matter (NOM) is a general term assigned to all the organic compounds present in natural water, i.e. surface, ground and soil pore water (Świetlik et al., 2004; Uyguner-Demirel and Bekbolet, 2011; Delay et al., in press). Recent experimental results demonstrated that dissolved NOM (particles $<0.45 \mu \mathrm{m}$ ) constitutes an important fraction of $\mathrm{dE}_{\mathrm{f}} \mathrm{OM}$ present in urban wastewater effluents (Filloux et al., 2012a; Yu et al., 2015). The bulk volume of $\mathrm{dE}_{\mathrm{f}} \mathrm{OM}$ was proved to contain humic-like materials associated with the corresponding drinking water sources (Jarusutthirak and Amy, 2007). The characteristics of $\mathrm{dE}_{\mathrm{f}} \mathrm{OM}$ and dissolved NOM overlap extensively (Krasner et al., 2009); however, the aromatic moieties present in $\mathrm{dE}_{\mathrm{f}} \mathrm{OM}$ are probably of different origin than those of dissolved NOM (Drewes and Croué, 2002). Dissolved NOM is a complex mixture of aromatic and aliphatic molecules with a broad spectrum of chemical structures and molecular weight distribution (MWD), highly influenced by its origin, climatic conditions and the biogeochemical cycles of the surrounding environments (Frimmel, 1998; Ghabbour and Davies, 2001; Leenheer, 2004; Fabris et al., 2008). The chemical composition and properties of dissolved NOM may also vary within the same location seasonally, due to rainfall, snowmelt runoff, floods or droughts (Matilainen et al., 2010).

NOM originates from both allochthonous (watershed or terrestrial) and autochthonous (algal or in situ) sources (McKnight et al., 2001; Henderson et al., 2008). Allochthonous NOM is transported within the watershed and is derived from and influenced by the geology, land-use, and hydrology of its origin, while autochthonous NOM is generated within the water column through microbial and algal activity (Hudson et al., 2007). Allochthonous NOM generally exhibits humic character, while autochthonous NOM principally consists of soluble algogenic organic matter that mainly includes glycolic acid, carbohydrates, polysaccharides, amino acids, peptides, enzymes, and toxins (Her et al., 2004). Some researchers have reported that the allochthonous NOM is more aromatic than the autochthonous NOM (Zumstein and Buffle, 1989).

Whilst the fractions are more operationally than structurally defined, organic compounds present in dissolved NOM can be judiciously assigned to a particular fraction according to their chain length and functional groups. The most accepted categories of dissolved NOM are hydrophobic and hydrophilic organics with further identification as acid/base/ neutral compounds (Świetlik et al., 2004). The largest fraction of dissolved NOM comprises hydrophobic acids, which constitute approximately $50 \%$ of the DOC in natural water 


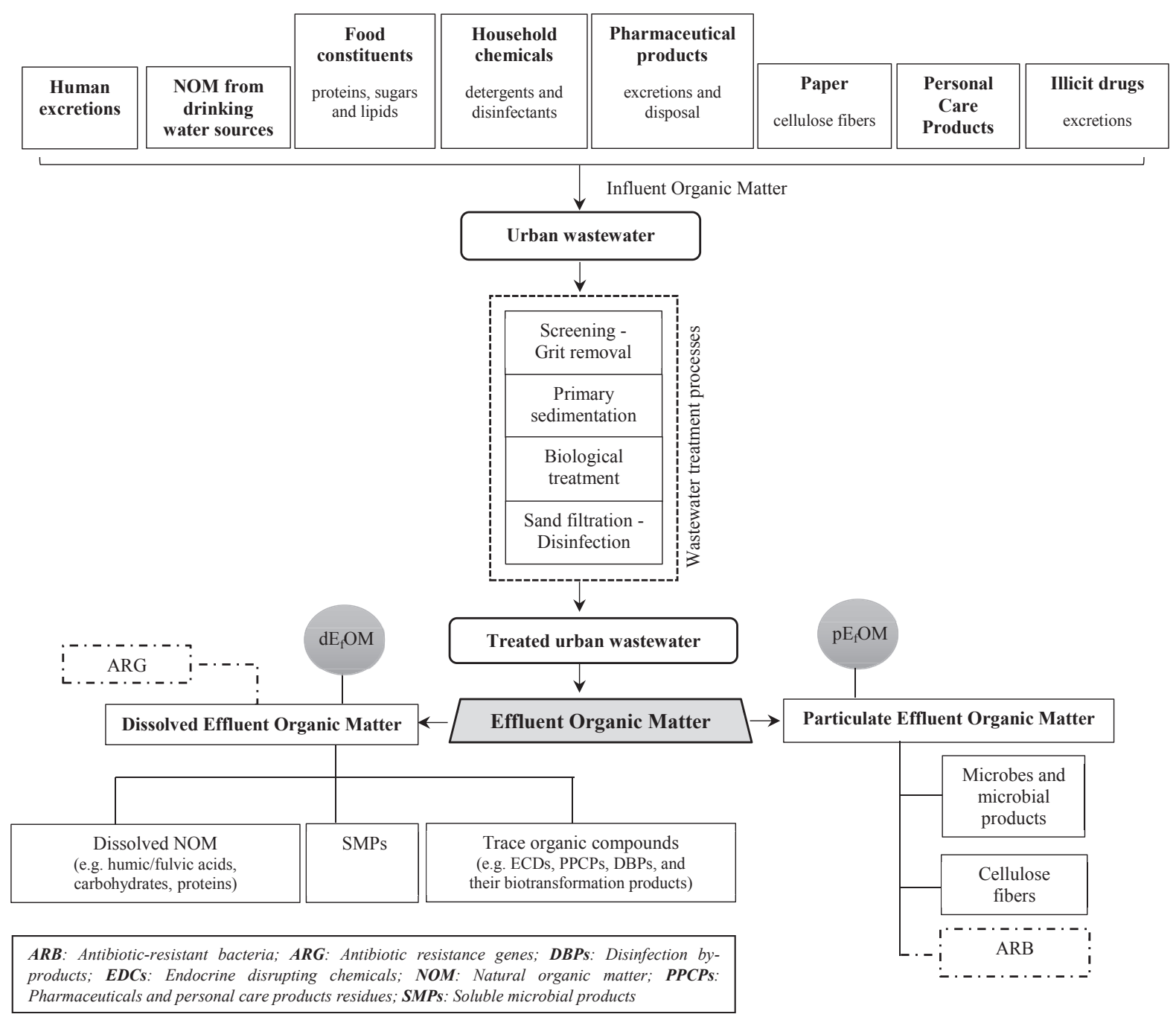

Fig. 1 - The origin of the $\mathrm{dE}_{\mathrm{f}} \mathrm{OM}$ in biologically treated urban wastewater effluents.

(Thurman, 1985). Hydrophobic dissolved NOM principally consists of humic substances incorporating humic acids, fulvic acids, and humin. Humic substances are traditionally defined according to their solubility in water. Humic acid is not soluble in water at $\mathrm{pH}<2$ but becomes soluble at more alkaline conditions. Fulvic acid is soluble at all $\mathrm{pH}$ values, while humin is insoluble at all pH conditions (Gaffney et al., 1996). Hydrophobic dissolved NOM is characterized to be rich in aromatic carbon, phenolic structures and conjugated double bonds, while the hydrophilic fraction incorporates more aliphatic carbon and nitrogenous compounds, such as carboxylic acids, carbohydrates, and proteins. In their comprehensive reviews, McDonald et al. (2004) and Sutton and Sposito (2005) reported the origins and possible molecular structure of NOM. In general, they reported that NOM from different origins (e.g., humic substances formed from either lignin or by polymerization/condensation reactions of biomolecules) appears to have different characteristics with abundance of various functional groups. The detailed chemical pathways of the formation of NOM are yet not defined, and it is not clear whether the source of NOM is reflected in the resulting humic substances.

\subsection{Soluble microbial products}

Experimental results showed that a significant fraction of $\mathrm{dE}_{\mathrm{f}} \mathrm{OM}$ in biologically treated wastewater contains soluble organic products of microbial origin, or soluble microbial products (SMPs) (Baskir and Hansford, 1980; Saunders and Dick, 1981). These products are ubiquitous in biological treatment and have been found to comprise the majority of the DOC of wastewater effluents (Shon et al., 2006a). According to Barker and Stuckey (1999), SMPs are biologically derived either from substrate metabolism during biomass growth (utilization-associated products [UAPs]) or from cell lysis during biomass decay (biomass-associated products [BAPs]). UAPs are generated at a rate proportional to the substrate utilization rate, while BAPs' production is proportional to the biomass concentration. Several process parameters that might influence the production and properties of SMPs include the: organic loading rate, hydraulic and solid retention time (HRT, SRT), substrate type, biomass concentration, temperature, reactor type, etc (Kuo et al., 1996; Aquino and Stuckey, 2004; Liang et al., 2007). A significant decrease in the amount of SMPs was reported to occur in a sequencing 
batch reactor (SBR) as the SRT increased from 3.3 to 27.7 days (Esparza-Soto et al., 2011). Humic substances, carbohydrates, and proteins have been successfully identified as the major components of SMPs, though their precise composition still remains unclear (Liang et al., 2007).

Although the presence of SMPs in biological treatment systems has already been acknowledged in the literature, there is lack of information regarding their formation and composition. Namkung and Rittmann (1986) investigated the formation of SMPs by utilizing a laboratory-scale biofilm reactor and naturally-grown oligotrophs. The experimental results showed that $\sim 85 \%$ of the effluent DOC consisted of SMPs, which contained mainly organic compounds with high molecular weight (MW). In another study performed by Barker et al. (2000), the chemical composition, MWD, and biodegradability of SMPs in an anaerobic baffled reactor (ABR) were examined. This compartmentalized reactor could achieve partial separation of acidogenic and methanogenic processes, and separation of the HRT and SRT. This study revealed that high MW (100-300 kDa) compounds (i.e., heteropolysaccharides and lipopolysaccharides) were concentrated in the middle compartments of the reactor and represented $22 \%$ of the effluent chemical oxygen demand (COD). On the other hand, low MW ( $<1 \mathrm{kDa})$ compounds (i.e., alcohols and carboxylates) were detected in the first compartment of the ABR and in the final effluent, constituting $36 \%$ of the effluent COD. SMPs production was found to decrease with decreasing the HRT, while the increase of temperature resulted in higher SMPs production. Jarusutthirak and Amy (2007) have examined the formation of SMPs during the biological treatment of organic matter in an SBR. According to their results, the organic compounds present in a synthetic wastewater to which glucose was added, were totally transformed to BAPs, consisting mainly of high MW fractions of organic matter, possibly originating from cell lysis. Aquino and Stuckey (2004) investigated the formation of SMPs using anaerobic chemostats fed on glucose $(\sim 10 \mathrm{gCOD} / \mathrm{L})$ and they reported that under steady-state conditions, $82-98 \%$ of the effluent COD was attributed to SMPs. SMPs accumulation was also found to be proportional to the dose of toxicant spiked into the chemostats (chromium and chloroform which were used to be representatives of heavy metals and chlorinated organic compounds, respectively). Cell lysis was reported to be the main mechanism contributing towards SMPs accumulation in the presence of chromium and chloroform.

In general, it is not yet clear what the characteristics of SMPs are, and whether they are produced during biomass growth or cell lysis. Nevertheless, this aspect is of great importance with regard to the optimization of biological wastewater treatment processes.

\subsection{Contaminants of emerging concern}

During the last decade, innovative analytical techniques have enabled the identification and quantitation of a wide variety of chemical microcontaminants, widely known as 'contaminants of emerging concern (CECs)' in treated wastewater effluents (Fatta-Kassinos et al., 2011b). According to the NORMAN Association of reference laboratories, research centres, and related organizations for monitoring of emerging environmental substances (http://www.norman-network. net), the term 'contaminants of emerging concern' does not necessarily refer to 'new substances', i.e., newly introduced chemicals and their transformation products and/or metabolites, but also refers to chemicals (both synthetic and naturally occurring compounds) with previously unrecognized adverse effects on the environment. CECs include endocrine disrupting compounds (EDCs), pharmaceuticals and personal care products residues (PPCPs), and many other complex compounds (plasticisers, surfactants, pesticides, detergents, nanoparticles, etc.) (Nikolaou et al., 2007; Fatta-Kassinos et al., 2011b).

These microcontaminants have been detected in the $\mathrm{dE}_{\mathrm{f}} \mathrm{OM}$ at the $\mathrm{ng} \mathrm{L^{-1 }}$ to the $\mu \mathrm{g} \mathrm{L}^{-1}$ level (Heberer, 2002). This indicates that the conventional treatment technologies do not completely remove microcontaminants and this leads to their subsequent release into the aquatic environment through discharge and/or reuse applications. Hydrophobic microcontaminant residues are accumulated in $\mathrm{pE}_{\mathrm{f}} \mathrm{OM}$, while hydrophilic ones are expected to occur at higher concentration in $\mathrm{dE}_{\mathrm{f}} \mathrm{OM}$. An exhaustive literature review has already been provided on the occurrence of these microcontaminants in treated urban wastewater (Daughton and Ternes, 1999; Petrović et al., 2006, 2007; Watkinson et al., 2009; Fatta-Kassinos et al., 2011b; Michael et al., 2013).

Wastewater disinfection employed in many countries aims at reducing microbial contamination and preventing the spread of pathogens present in reclaimed wastewater into the environment. Chlorination is the most widely utilized disinfection process. $\mathrm{dE}_{\mathrm{f}} \mathrm{OM}$ can react with disinfectants (e.g., chlorine, chloramines), resulting thus in the generation of disinfection by-products (DBPs) (Crebelli et al., 2005). It has been generally considered to be the main DBPs precursor, and especially its hydrophobic portion (Liu et al., 2010). The hydrophilic low $\mathrm{MW} \mathrm{dE}_{\mathrm{f}} \mathrm{OM}$ though has also been reported to play a significant role in DBPs formation (Parsons et al., 2004; Hua and Reckhow, 2007). More than 700 compounds of DBPs have been reported in the literature (Richardson, 2003), among which trihalomethanes (THMs) and haloacetic acids (HAAs) are the two groups detected at higher concentrations in the disinfected wastewater (Krasner et al., 2009). In addition, a variety of nitrosamines (aliphatic, alicyclic and aromatic), such as $\mathrm{N}$-nitrosodimethylamine (NDMA), were frequently detected in wastewater effluents due to the exposure of organic nitrogen-containing compounds to chloramine (Pehlivanoglu-Mantasa et al., 2006; Krauss et al., 2009). It was reported (Sedlak et al., 2005) that the average concentration of NDMA in tertiary wastewater effluents is approximately 80 and $100 \mathrm{ng} \mathrm{L}^{-1}$ prior to and after disinfection, respectively. It is noted that SMPs which constitute the main portion of dissolved organic nitrogen (DON), are suspected to be the main precursors of the formation of nitrosamines. Brominated and iodinated DBPs have also been detected at high concentration levels in chlorinated wastewater (Richardson and Ternes, 2005). It is worth noting that the formation of DBPs is prevented in the case that UV-driven processes are employed as alternative means to chlorine for wastewater disinfection (Lazarova and Savoye, 2004; Nasser et al., 2006). Recently, it was demonstrated that Light 
Emitting Diodes (LEDs) seem to be promising in eliminating potentially pathogenic bacteria (coliform and enterococci) from wastewater effluents (Chevremont et al., 2012, 2013). Nonetheless, UV processes can also lead to the formation of toxic oxidation products whose biological potency should not be neglected (Fatta-Kassinos et al., 2011c).

$\mathrm{E}_{\mathrm{f}} \mathrm{OM}$ also contains a mixture of biological microcontaminants of emerging concern such as antibioticresistant bacteria and their genes (ARB\&ARG). To date, it has not yet been reported in which part $\left(\mathrm{pE}_{\mathrm{f}} \mathrm{OM}\right.$ or $\left.\mathrm{dE}_{\mathrm{f}} \mathrm{OM}\right)$ of the $\mathrm{E}_{\mathrm{f}} \mathrm{OM}$, the $\mathrm{ARB} \& A R G$ are accumulating. Nevertheless, it may be assumed that antibiotic-resistant bacteria are found in $\mathrm{pE}_{\mathrm{f}} \mathrm{OM}$, while their genes (or other mobile antibiotic resistance genetic elements such as plasmids which facilitate the transfer of antibiotic resistance genes between bacteria) may be detected in $\mathrm{dE}_{\mathrm{f}} \mathrm{OM}$. A recent review by Rizzo et al. (2013) highlights the prevalence and spread of ARB\&ARG into the environment since wastewater treatment plants (WWTPs) are regarded as the main hotspots for ARB\&ARG evolution. Resistance can also be promoted through horizontal gene transfer during the activated sludge treatment via conjugation, transduction and transformation (Zhang et al., 2009). WHO (2014) identified the development of resistance as one of the 'major global threats to the society' and recommends urgent coordinated action and intensive monitoring for the identification/surveillance of critical hotspots (e.g., WWTPs), aiming at reducing its propagation. Recently, a national strategy was released by the White House in US, in order to establish surveillance systems for tracking the spread of ARB (The White House, 2014). It is important to note that a new European COST Action (ES1403) under the title 'New and emerging challenges and opportunities in wastewater reuse (NEREUS)' (http://www.nereus-cost.eu) has recently initiated its activities that include among others ARB\&ARG monitoring and control and enhancement of sustainable wastewater reuse in light of current challenges at technological, economical and societal level.

\section{Characterization and quantification of dissolved organic matter}

During the last decades, substantial effort has been directed towards the characterization of $\mathrm{dE}_{\mathrm{f}} \mathrm{OM}$. The ill-defined nature of $\mathrm{dE}_{\mathrm{f}} \mathrm{OM}$ is due to the difficulty in determining the exact concentrations and classes of different compounds with varying structures and properties. Accordingly, various analytical techniques are used individually or in combination to provide adequate information on these substances.

$\mathrm{dE}_{\mathrm{f}} \mathrm{OM}$ is generally quantified in terms of surrogate parameters, such as COD, biochemical oxygen demand (BOD), dissolved or total organic carbon (DOC or TOC) and DON. The aforementioned parameters are routinely assessed by the WWTPs in their operational and quality control, with the aim to comply with the treated effluent discharge requirements. Nevertheless, these parameters can be regarded as poor indicators of the organic carbon source and do not offer any information on the structure of $\mathrm{dE}_{\mathrm{f}} \mathrm{OM}$.

A vast number of studies has been published on analytical methods for the structural characterization of the dissolved organic matter present in various aqueous matrices (Frimmel and Christman, 1988; Frimmel and Abbt-Braun, 1999; Hedges et al., 2000; O'Loughlin and Chin, 2001; Abbt-Braun et al., 2004; Uyguner-Demirel and Bekbolet, 2011; Kim and Dempsey, 2012; Quaranta et al., 2012). Given that this subject is very extensive, the purpose of this section is not to provide a complete literature review on this topic, but rather highlight some examples documenting the utilization of the most commonly applied analytical methods (i.e., fractionation, spectroscopic and chromatographic techniques) for the characterization of the dissolved organic matter present in various aqueous matrices (i.e., wastewater effluents, surface water, etc.). Table S1 (Supplementary data) provides a summary of recent studies on the characterization of the bulk volume of dissolved organic matter present in both wastewater effluents (i.e., $\mathrm{dE}_{\mathrm{f}} \mathrm{OM}$ ) and natural water (i.e., dissolved $\mathrm{NOM}$ ) the aim being to present the state-of-the-art analytical techniques and the general methodology currently employed for its characterization. A clear distinction between the studies focusing on the characterisation of dissolved NOM (e.g., surface water, groundwater, reservoirs) and the studies dealing with $\mathrm{dE}_{\mathrm{f}} \mathrm{OM}$ has been made, the latter being marked with an asterisk (*) in Table S1.

Among the various analytical methods applied for dissolved organic matter characterization, the most common methods include physicochemical, spectroscopic, chromatographic, and fractionation techniques. Also, pyrolysis in conjunction with mass spectrometry (MS) and/or gas chromatography (GC) has been utilized in some studies as a qualitative, rather than a quantitative technique (Sirivedhin and Gray, 2005). The advantage of the pyrolysis approach is that natural biopolymers present in dissolved organic matter, can be quantified using the specific fragments formed (Leenheer and Croué, 2003). Its major disadvantage however, is that this technique requires an isolation step prior to analysis.

The isolation of dissolved organic matter into different fractions is an established first step to gain information about its structure and functionality. The most frequently applied procedure for isolation/fractionation of dissolved organic matter is based on the column sorption technique in conjunction with ion-exchange resins, to simultaneously concentrate and separate specific organic components of dissolved organic matter into hydrophobic and hydrophilic fractions (Serkiz and Perdue, 1990; Abbt-Braun et al., 2004). An outline of the fractionation procedure in water and wastewater samples was reported by Leenheer (1981), while modifications of this general concept have been made by several investigators (Bolto et al., 1999; Ma et al., 2001; Imai et al., 2002; Marhaba et al., 2003; Świetlik et al., 2004; Kim and Dempsey, 2012). To separate the hydrophobic and hydrophilic substances and further the acidic, basic and neutral compounds in each fraction, the sample is sequentially passed through a neutral resin (XAD-8), a strong cation-exchange resin, and finally through a strong anion-exchange resin using acids and bases of various concentrations for elution.

It should be stressed that the fractionation procedure is operation-dependent and consequently, in order to produce comparable results for the amount and kind of organic 
substances present in each fraction, it is imperative to follow strictly the procedure. It is worth noting that although the $\mathrm{XAD}$ resin method has been employed by the US Geological Survey and the International Humic Substances Society, the yield is typically around only $40-60 \%$ and the procedure is laborious and may alter the structure of the organic matter. To this effect, reverse osmosis in combination with ion-exchange resins, used after membrane filtration, has also been employed with a higher yield for dissolved organic matter concentration and fractionation (Ma et al., 2001; Leenheer, 2009).

Alternatively, spectroscopic techniques, specifically the spectrophotometric absorbance recorded at specific wavelengths and fluorescence measured in excitation/emission or synchronous scan modes, have been successfully applied for the identification and characterization of dissolved organic matter (Baker, 2001; Bengraïne and Marhaba, 2004). The presence of chromophores (i.e., light-absorbing moieties usually $\mathrm{C}=\mathrm{C}$ and $\mathrm{C}=\mathrm{O}$ double bonds) in dissolved organic matter are detected through UV/Vis absorption properties. Another approach to approximate the aromaticity of dissolved organic matter is the specific UV absorbance (SUVA). SUVA is defined as the samples' UV absorbance at $254 \mathrm{~nm}\left(\mathrm{UV}_{254}, \mathrm{~m}^{-1}\right)$ divided by the corresponding DOC (mg L $\mathrm{L}^{-1}$ ) concentration of the solution. This provides a quantitative evaluation of the aromatic content of the organic matter per unit concentration of organic carbon (Weishaar et al., 2003). High SUVA values indicate that the dissolved organic matter is largely composed of hydrophobic and high MW organic compounds, while low SUVA values indicate that the water contains mainly hydrophilic organic compounds of low MW and low charge density (Matilainen et al., 2010). Croué et al. (1999) employed carbon-13 nuclear magnetic resonance $\left({ }^{13} \mathrm{C}\right.$ NMR) in order to correlate SUVA and the aromatic carbon content of dissolved organic matter. However, due to the complex nature of dissolved organic matter comprising a large number and a wide variety of chromophores without a unique and easily distinguishable absorption spectrum, UV spectroscopic methods cannot provide precise understanding of its structural characteristics. A recent approach based on fluorescence excitation and emission spectroscopy coupled with parallel factor analysis was employed by $\mathrm{Yu}$ et al. (2015) as a means to $\mathrm{dE}_{\mathrm{f}} \mathrm{OM}$ quantification. The results demonstrated that tyrosine-like substances (mainly UAPs of SMPs), tryptophan-like substances, as well as fulvic-like and humic-like substances were the main constituents persisting in $\mathrm{dE}_{\mathrm{f}} \mathrm{OM}$.

A highly sensitive technique which can provide qualitative molecular information about the fluorophores of dissolved organic matter, is the fluorescence spectroscopy (i.e., emission/excitation measurements, as well as multidimensional techniques) (Świetlik and Sikorska, 2004; Carvalho et al., 2008; Korak et al., 2014). Fluorescence characteristic spectra are highly related to structure and functional groups in molecules (Świetlik and Sikorska, 2004). Previous work for the characterization of dissolved organic matter with fluorescence spectroscopy revealed that humic substances typically fluoresce in the excitation range of $300-400 \mathrm{~nm}$ and the emission range of 400-500 nm (Goslan et al., 2004). However, fluorescence studies of dissolved organic matter and identification of particular fluorophores remain difficult and contradictory owing to its complex chemical structure and methodology issues, such as spectral overlapping, peak shifting, and peak broadening (Chen et al., 2002). The linear relationship between fluorescence intensity and DOC was found to deviate from linearity at environmentally relevant concentrations (Korak et al., 2014). Hudson et al. (2007) presented a comprehensive review on the application of fluorescence spectroscopic techniques for the measurement of the intrinsic fluorescence of dissolved organic matter in marine water, freshwater and wastewater.

Another commonly used technique for the characterization of dissolved organic matter is the high performance size-exclusion chromatography (HPSEC) which is commonly used to determine the MWD of dissolved organic matter and to fractionate humic substances (Fabris et al., 2008; Quaranta et al., 2012). The advantages of HPSEC over other analytical techniques are: small sample volumes, minimal sample pretreatment, ease and speed of analysis, and the ability to use several detectors (i.e., UV/Vis, fluorescence and DOC analyzers) (O'Loughlin and Chin, 2001). HPSEC and SUVA are employed to reveal information about the composition and properties of dissolved organic matter and its fractions (Cheng et al., 2005; Korshin et al., 2009).

Recent advances in mass spectrometry systems (e.g., Orbitrap Fourier transform mass spectrometry [FT-MS] and Electrospray ionization Fourier transform ion cyclotron resonance mass spectrometry [ESI-FT-ICR-MS]) were employed to provide a detailed chemical fingerprint of $\mathrm{dE}_{\mathrm{f}} \mathrm{OM}$. It has been shown that sulphur-containing compounds are present in $\mathrm{dE}_{\mathrm{f}} \mathrm{OM}$, which can be attributed to surfactants (linear alkyl benzene sulfonates), their associated-products such as dialkyl tetralin sulfonates, as well as their biodegraded products (sulfophenyl carboxylic acids) (Gonsior et al., 2011; Urai et al., 2014).

The complex and diverse structure of dissolved organic matter requires a multi-method analytical characterization, thereby providing an adequate and comprehensive image of its molecular structure and properties. A validation and correlation of data deriving from different and independent characterization techniques (i.e., isolation/fractionation and physicochemical/spectroscopic/chromatographic methods) is essential, in order to gather more detailed structural information.

\section{Effects and challenges associated with $\mathrm{dE}_{\mathrm{f}} \mathrm{OM}$ and wastewater reuse}

Although treated wastewater reuse schemes in agricultural and landscape irrigation are becoming more important due to increasing water shortages, rising costs, and regulatory Directives (e.g., European Council Directive 91/271/EEC), the current knowledge on the potential effects that $\mathrm{dE}_{\mathrm{f}} \mathrm{OM}$ might induce to the aquatic environment is limited. The European Council Directive 91/271/EEC concerning urban wastewater treatment in Article 12 states that 'Treated wastewater shall be reused whenever appropriate. Disposal routes shall minimize the adverse effects on the environment'. To date, the ecotoxicological evaluation of urban wastewater in Europe 
has been indirectly recognized through the implementation of the Water Framework Directive (2000/60/EC). Lifting the existing ecotoxicological barriers that are related to wastewater reuse has been placed as a top priority by various European Initiatives such as the Joint Programming Initiative of Water Challenges, the European Blueprint of Water, and the Strategic Implementation Plan of the European Innovation Partnership on Water. European Commission has also started working towards the preparation of a European Directive on Wastewater Reuse (CEN/SABE, 2014). To date, countries with organized wastewater reuse schemes have developed national or regional regulations/guidelines based on conventional chemical (COD, DOC, BOD, total suspended solids [TSS], heavy metals, etc.) and microbiological (Escherichia coli, eggs of intestinal worms, etc.) parameters, which are insufficient for performing an environmental risk analysis (Vasquez and Fatta-Kassinos, 2013).

In general, dissolved organic matter has been shown to exhibit a contradictory effect towards various aquatic organisms. It contains a variety of ligands that facilitate binding of inorganic (e.g., metal ions) and organic microcontaminants, thus potentially reducing their bioavailability to exposed organisms (Sarathy and Allen, 2005; Buzier et al., 2006; Pernet-Coudrier et al., 2008). On the other hand, it can induce toxic effects by its adsorption on cell membranes. Which effect prevails in real environmental conditions depends on the physicochemical characteristics of the dissolved organic matter, the functional biology of different species and the exposure conditions (Sánchez-Marín et al., 2011). From an ecotoxicological point of view, the biological effects of dissolved NOM are also presented herein considering the fact that the latter was proved to be a key fraction of the bulk volume of $\mathrm{dE}_{\mathrm{f}} \mathrm{OM}$ (and especially the allochthonous portion) (Yu et al., 2015), aiming at facilitating the understanding of such effects and assessing its contribution to the overall biological effect.

A limited number of studies have addressed the great binding potential of $\mathrm{dE}_{\mathrm{f}} \mathrm{OM}$ present in treated wastewater effluents to complex metals, alleviating thus metal toxicity to aquatic organisms. Pernet-Coudrier et al. (2008) reported that $\mathrm{Cu}$ toxicity towards Daphnia magna was reduced in the presence of $\mathrm{dE}_{\mathrm{f}} \mathrm{OM}$ subjected to $\mathrm{RO}$ followed by fractionation with XAD-4,8 resins (DOC $<0.5 \mathrm{mg} \mathrm{L}^{-1}$ ). The critical effect to $D$. magna was assessed using the biologically determined constant $\left(\mathrm{k}_{\mathrm{bio}}, \mathrm{L} \mathrm{mg}_{\mathrm{C}}^{-1}\right.$ ) for each $\mathrm{dE}_{\mathrm{f}} \mathrm{OM}$ fraction (i.e., hydrophobic, transphilic, hydrophilic) considering the free $\mathrm{Cu}$ concentration. The results showed that the labile toxic $\mathrm{Cu}$ concentration was slightly higher in the case of hydrophobic and transphilic fractions compared to hydrophilic, while compounds with low SUVA (e.g., proteins or polysaccharides) were suspected to play a significant role in the Cu complexation by $\mathrm{dE}_{\mathrm{f}} \mathrm{OM}$. The biologically determined constant values for hydrophobic, transphilic and hydrophilic fractions were found to be 9.9, 11.3 and $9.8 \mathrm{~L} \mathrm{mg}_{\mathrm{C}}^{-1}$, respectively. A similar constant $\left(\mathrm{k}_{\text {bio }}=8.4 \mathrm{~L} \mathrm{mg}_{\mathrm{C}}^{-1}\right)$ was reported by Buzier et al. (2006) who studied the toxicity of D. magna in the presence of filtered wastewater (raw $\left[\mathrm{DOC}=4.7-5.5 \mathrm{mg} \mathrm{L}^{-1}\right.$ ] and treated [DOC $\left.=1.1-2.3 \mathrm{mg} \mathrm{L}^{-1}\right]$ ) from two WWTPs. The complexation of $\mathrm{Cu}$ and $\mathrm{Cd}$ by $\mathrm{dE}_{\mathrm{f}} \mathrm{OM}$ was reported to be strongly depended on the $\mathrm{dE}_{\mathrm{f}} \mathrm{OM}$ concentration, with the binding capacities to be lower in the case of treated wastewater possibly due to the ligand removal during treatment. In a study performed by Sarathy and Allen (2005), the complexation of Cu by biologicalderived macromolecules (i.e., SMPs) present in $\mathrm{dE}_{\mathrm{f}} \mathrm{OM}$ (DOC $=10 \mathrm{mg} \mathrm{L}^{-1}$ ) was demonstrated. Worms et al. (2010) investigated the role of $\mathrm{dE}_{\mathrm{f}} \mathrm{OM}$ from WWTPs on the speciation of $\mathrm{Cd}$ and $\mathrm{Pb}$ and their uptake by the green alga Chlorella kesslerii. It was demonstrated that $\mathrm{dE}_{\mathrm{f}} \mathrm{OM}$ induced complexation of $\mathrm{Pb}$ to a greater extent than $\mathrm{Cd}$, which is consistent with the findings of Buffle (1988). In addition, the intracellular $\mathrm{Cd}$ and $\mathrm{Pb}$ contents in the algae were reduced due to their complexation by $\mathrm{dE}_{\mathrm{f}} \mathrm{OM}$. A high complexation of $\mathrm{Zn}$ by $\mathrm{dE}_{\mathrm{f}} \mathrm{OM}$ (DOC $=15 \mathrm{mg} \mathrm{L}^{-1}$ ) was reported by Louis et al. (2014), which was mainly attributed to the hydrophilic fraction, i.e., binding $60-75 \%$ of total $\mathrm{Zn}$.

Dissolved NOM present in surface water has been extensively studied with respect to its capacity to complex metals. Lamelas et al. (2005) have demonstrated that polysaccharides, in particular alginic acid, may exhibit $\mathrm{Pb}$ complexing properties and a protective role, with respect to the green alga $C$. kesslerii. Bioavailability models, such as the biotic ligand model (BLM), have been developed by De Schamphelaere et al. (2004) aiming at predicting the effect of dissolved NOM on metal speciation and toxicity towards D. magna. This study showed that the predictive capacity of the acute $D$. magna Cu-BLM was improved taking into account the dissolved NOM variability. Schwartz et al. (2004) showed that toxicity of $\mathrm{Cu}$ and $\mathrm{Pb}$ towards rainbow trout Oncorhynchus mykiss was decreased in the presence of dissolved NOM, while the degree of protection varied with respect to NOM source (i.e., allochthonous and autochthonous). In the case of Cd, no variability in toxicity to freshwater fish between the different types of dissolved NOM was observed. Dissolved NOM was also reported to reduce Ag toxicity to D. magna, due to its strong affinity to bind $\mathrm{Ag}$ (Glover and Wood, 2005). In a recent study performed by Louis et al. (2014), the strong affinity of dissolved NOM to bind $\mathrm{Zn}$ was demonstrated. Moreover, recent investigations with $\mathrm{Pb}, \mathrm{Hg}, \mathrm{Cu}, \mathrm{Cd}$ and $\mathrm{Ni}$ have demonstrated the higher metal binding ability of hydrophilic dissolved NOM compared to humic substances (Baken et al., 2011; Muresan et al., 2011).

The aforementioned studies reveal that a fundamental understanding of the 'protective' effect of both $\mathrm{dE}_{\mathrm{f}} \mathrm{OM}$ and dissolved NOM and their metal complexation capacity in various environmental systems is crucial. Since biological effects due to metals are always initiated by metal bioaccumulation, more research on the mechanisms underlying bioaccumulation will lead to an improved evaluation of the impacts of metals on aquatic organisms. In addition, the results obtained with respect to the metal complexation by dissolved organic matter suggest that the chemical heterogeneity and size dependence of metal binding have to be taken into account to better understand the overall effects of $\mathrm{dE}_{\mathrm{f}} \mathrm{OM}$ on the interactions of metals with aquatic organisms.

In contrast to the aforementioned 'protective' role of dissolved NOM, direct adverse effects of dissolved NOM on aquatic organisms have also been observed. For example, dissolved NOM molecules may accumulate on cellular membranes, inducing toxic effects and altering their basic 
functions (Campbell et al., 1997; Wood et al., 2003; Glover et al., 2005; Galvez et al., 2008). Campbell et al. (1997) reported the sorption of dissolved NOM on the membranes of algae and fish gill cells under acidic $\mathrm{pH}$ conditions due to the formation of hydrogen bonds on the biological surfaces or the production of hydrophobic interactions between dissolved NOM and the membrane. In a similar study by Galvez et al. (2008), the ability of dissolved NOM in altering the fundamental physiological properties of fish gills under acidic conditions was demonstrated. Timofeyev et al. (2006) reported that dissolved NOM had an adverse impact on the amphipods Gammarus lacustris and Gammarus tigrinus by inducing internal oxidative stress, leading to the membrane lipid structures deterioration and microorganisms' mortality. Many authors reported also that humic compounds present in dissolved NOM can be adsorbed onto the algal membrane surfaces, affecting thus the membrane permeability and functionalities (e.g., charge, binding sites, speciation) (Knauer and Buffle, 2001; Slaveykova et al., 2003; Lamelas et al., 2009). Vigneault et al. (2000) found that humic substances were able to penetrate into phytoplankton and other model membranes, which led to enhanced permeability at neutral $\mathrm{pH}$ conditions. The above results suggest that since membrane permeability is highly affected by $\mathrm{pH}$, the interactive effects of dissolved NOM on membrane permeability of various species should be studied at a range of $\mathrm{pH}$ values in future investigations. An interesting study by Meinelt et al. (2004) showed also that the exposure of young swordtail (Xiphophorus helleri) to high concentrations of synthetic humic substances with a median particle mass of $1500 \mathrm{Da}$ (HS1500) significantly affected the physiological functions and slightly altered the sex ratio of the fish. The weak feminization has been attributed to the presence of alkylphenols in HS1500. However, further studies should be performed in order to confirm the molecular mechanisms of this effect and to investigate whether this behaviour may be appear to other fish or amphibian species.

To date, there are no available studies in the scientific literature dedicated to the toxic effects that can be elicited by $\mathrm{dE}_{\mathrm{f}} \mathrm{OM}$. However, since dissolved NOM is a key portion of $\mathrm{dE}_{\mathrm{f}} \mathrm{OM}$ and the chemical characteristics of effluent-derived and naturally-derived organic compounds overlap extensively (Drewes and Croué, 2002), it may be assumed that at least similar effect prevails in the case of exposing aquatic microorganisms to $\mathrm{dE}_{\mathrm{f}} \mathrm{OM}$. As a part of water quality monitoring programmes, whole effluent toxicity (WET) tests have been applied to regulate discharges in the United States for over a decade (USEPA, 1991). In a recent study by Vasquez and Fatta-Kassinos (2013), four organisms from different trophic levels were used for the WET testing of treated wastewater, namely, P. subcapitata, D. magna, Artemia salina and Vibrio fischeri. The ecotoxicological assessment indicated the presence of toxicity throughout the sampling periods and importantly, an increase of the toxicity of the treated wastewater during summer compared to winter. This observation is in agreement with that reported by Kosmala et al. (1999), using the 7-day Ceriodaphnia dubia chronic toxicity test. It has been clearly shown that $P$. subcapitata was more sensitive than D. magna to treated wastewater, while V. fischeri and A. salina were found to be less sensitive. Even though correlations were found to exist among some species and physicochemical parameters (e.g., COD), these parameters were not able to explain the toxicity mechanisms, implying a more complex interaction scheme.

As for urban wastewater use in agricultural irrigation, little research has been conducted on the environmental risks associated with $\mathrm{dE}_{\mathrm{f}} \mathrm{OM}$, since all studies are devoted to specific microcontaminants present in the treated wastewater (e.g., xenobiotic organic compounds, heavy metals, etc.). Fatta-Kassinos et al. (2011a) presents an extensive review on the toxicity (acute and chronic) of various xenobiotic compounds, as well as their accumulation in soil and their uptake by plants through wastewater reuse. Muñoz et al. (2009) investigated the potential environmental risks of crop irrigation using secondary treated urban wastewater containing 27 micropollutants (PPCPs, pesticides, heavy metals, etc.). Pharmaceuticals and heavy metals were assumed to be the main contributors to the risk and the need for tertiary treatment prior to reuse was highlighted. In a recent review (Pedrero et al., 2010), the fundamentals of agricultural irrigation using treated urban wastewater and the status of wastewater reuse in the Mediterranean basin (i.e., Greece and Spain) along with studies related to the effects on soils and plants were presented. The focus, however, of this study was the effect of specific metals present in the treated wastewater, rather than $\mathrm{dE}_{\mathrm{f}} \mathrm{OM}$. In addition, the status of the treated wastewater reuse in Greece, Israel, Italy and Cyprus was recently examined by Kalavrouziotis et al. (2013). The authors underlined the necessity for research on the safe wastewater reuse strategies with respect to the presence of heavy metals and xenobiotics in the treated wastewater, in order to comply with future needs of high-quality effluent. The potential uptake of microcontaminants present in $\mathrm{dE}_{\mathrm{f}} \mathrm{OM}$ by plants in soils irrigated with reclaimed wastewater is of outmost concern for unrestricted effluent utilization. Boxall et al. (2006) investigated the potential of various pharmaceuticals to be accumulated in soil and be taken up by plants used for human consumption. The analyses indicated that some compounds were present in soils for at least 5 months following application. Also, the uptake of pharmaceuticals into carrot roots, lettuce leaves, and cucumber plants has been observed by Shenker et al. (2011) and Wu et al. (2013). An interesting study by Malchi et al. (2014), revealed that a number of pharmaceuticals can be taken up by various wastewater-irrigated crops, while it was reported that the threshold of toxicological concern of lamotrigine can be reached for a child at a daily consumption of half a carrot ( $60 \mathrm{~g})$ irrigated with wastewater. In addition to the lack of studies, there is a methodological gap in environmental risk assessment (ERA) of wastewater irrigation, since guidelines (EC-European Commission, 2003) recognize only two possible routes for organic microcontaminants to enter the soil compartment, i.e., aerial deposition and application of wastewater sludge.

During the last decade, microcontaminants persisting in $\mathrm{dE}_{\mathrm{f}} \mathrm{OM}$ have been quantified, thus more chemicals need to be evaluated for safe wastewater reuse (Petrović and Barceló, 2006; Fatta-Kassinos et al., 2011a). The majority of these microcontaminants are not currently regulated although many of these compounds (even at low concentrations) are known or suspected for impacts to the aquatic environment (Weber et al., 2006). 
During wastewater disinfection, $\mathrm{dE}_{\mathrm{f}} \mathrm{OM}$ can react with disinfectants resulting in the formation of various DBPs, with potential endocrine disruption and (geno)toxic effects (Richardson, 2003; Krasner et al., 2009; Wu et al., 2014). The list of DBPs identified in disinfected wastewater has been expanded during the last years as a result of the improved analytical tools, from THMs and HAAs to an extensive list of halogenated and non-halogenated organic or inorganic species (Crebelli et al., 2005; Sun et al., 2009). Yet, the formation of DBPs during wastewater disinfection has so far received much less attention compared to the drinking water-derived DBPs, the latter being regulated in several countries (Singer and Bilyk, 2002; Mosteo et al., 2009). Previous studies (Chu et al., 2010) reported that SMPs, which are enriched with nitrogen-containing compounds, constitute the main precursors to the formation of DBPs. Brominated and iodinated DBPs have also been recognized as toxicologically important because the latter were proved to be much more carcinogenic than their chlorinated analogues (Richardson and Ternes, 2005; Sirivedhin and Gray, 2005; Yang et al., 2005). According to WHO (2008), NDMA, which has been identified as a primary disinfection by-product of wastewater chloramination, has potential carcinogenic and genotoxic effects.

The presence of pharmaceutical compounds in $\mathrm{dE}_{\mathrm{f}} \mathrm{OM}$ is also of major concern. Diclofenac, oestradiol (E2) and ethinyl-estradiol (EE2) are included into the European Union priority list of compounds known to pose a significant risk to surface water. In April 2013, the Council and the European Parliament reached an informal agreement on priority substances in the field of water policy. These compounds were included in a special 'watch list' that will be monitored but do not yet have an Environmental Quality Standard (EQS) (COM, 2011). In addition, the relation between wastewater and antibiotic resistance is now recognized since urban wastewater contains a variety of ARB\&ARG (Rizzo et al., 2013). Furthermore, (i) the wastewater biological treatment stage itself, constitutes a reactor capable to promote the horizontal gene transfer of resistance among bacteria, and (ii) resistance can develop due to the continuous contact of bacteria and antibiotics. Even though the presence of antibiotics in the treated urban wastewater and the promotion/dissemination of antibiotic resistance have been documented in the scientific literature (Baquero et al., 2008; Zhang et al., 2009; Michael et al., 2013; Rizzo et al., 2013), knowledge on the actual effects of reuse in relation to the evolution and spread of antibiotic resistance through the release of resistance genes, is currently not consolidated and there is not yet any European legislation to address this issue. The Environmental Monitoring Strategy Team of the European Committee on Standardisation (CEN/ SABE) has published in 2014, a Strategic Position Paper on 'Wastewater reuse and implications for future standardisation', which recommends to (i) evaluate the antibiotic resistance accumulation in soil and growing media for food crops during wastewater reuse, (ii) define acceptable threshold values of resistance in the environment and (iii) develop harmonised risk assessment protocols for the determination of resistance spread and transmission to humans and the food chain. In addition, it asks for the identification of indicators concerning the contaminants of emerging concern to be monitored during wastewater reuse applications (CEN/SABE, 2014). Even though the priority microcontaminants constitute only a very small portion of the chemical composition of $\mathrm{dE}_{\mathrm{f}} \mathrm{OM}$, there is an urgent need to launch an intensive research towards the understanding of their interactions with $\mathrm{dE}_{\mathrm{f}} \mathrm{OM}$ and their potential environmental risks.

\section{Assessment of advanced treatment performance on $\mathrm{dE}_{\mathrm{f}} \mathrm{OM}$ removal}

The great structural complexity and chemical stability of $\mathrm{dE}_{\mathrm{f}} \mathrm{OM}$ impose challenges to the WWTPs for better operational optimization and proper process control. Also, in the context of the safe reuse of reclaimed wastewater, proper management of $\mathrm{dE}_{\mathrm{f}} \mathrm{OM}$ and associated microcontaminants should be adopted especially where strict guideline limits may be developed. Efforts should be put by the wastewater treatment facilities to invest in additional treatment processes to minimize the residual $\mathrm{dE}_{\mathrm{f}} \mathrm{OM}$ resulting from the conventional biological treatment. In recent years, considerable efforts have been made with respect to the application of advanced treatment technologies, such as membrane filtration, activated carbon adsorption, anion-exchange resins and advanced chemical oxidation processes, capable of removing significant amounts of $\mathrm{dE}_{\mathrm{f}} \mathrm{OM}$. Table 1 provides an overview of the recent work undertaken in this field demonstrating the removal of $\mathrm{dE}_{\mathrm{f}} \mathrm{OM}$ present in biologically treated wastewater effluents following advanced treatment. $\mathrm{dE}_{\mathrm{f}} \mathrm{OM}$ removal was assessed in terms of organic carbon measurements and $\mathrm{UV}_{254}$ absorbance. Complementary information regarding the experimental conditions, the organic load, and the main findings as reported by studies presented herein are included. In the subsequent section, special emphasis is devoted to the key parameters associated with the efficiency of each process regarding $\mathrm{dE}_{\mathrm{f}} \mathrm{OM}$ removal. It is important to note that the number of studies dealing with the assessment of advanced treatment in removing $\mathrm{dE}_{\mathrm{f}} \mathrm{OM}$ is limited compared to those focussing on the advanced treatment for the removal of dissolved NOM present in natural water (e.g., surface water, groundwater, reservoir, etc.), nonetheless the latter was beyond the scope of this review.

\subsection{Membrane filtration and separation processes}

Membrane-based processes are increasingly being used in wastewater treatment to obtain a high quality final effluent for various end-uses. Membrane systems have been used as substitutes for secondary settling basins in conventional activated sludge (CAS) treatment plants (i.e., membrane bioreactors-MBRs), thus limiting biomass separation problems and making it possible to work with high biomass concentrations in the biological reactors (Alonso et al., 2001). The effluent quality achieved with MBRs is improved compared to CAS with respect to $\mathrm{pE}_{\mathrm{f}} \mathrm{OM}$ removal, resulting in a final effluent with $5-10 \mathrm{mg} \mathrm{L}^{-1}$ of DOC and $<2 \mathrm{mg} \mathrm{L}^{-1}$ of TSS (Melin et al., 2006). Microfiltration (MF) and ultrafiltration (UF) have been described as very effective in reducing $\mathrm{pE}_{\mathrm{f}} \mathrm{OM}$, large colloids and bacterial cells from wastewater (Alonso et al., 2001; Filloux et al., 2012a). While the pores in MF and UF are 
Membrane filtration and separation processes

Wastewater effluent $\quad \mathrm{COD}=165 \mathrm{mg} \mathrm{L}^{-1}$

|primary

treatment|

Wastewater effluent CAS, sequencing batch reactor

Wastewater effluent |CAS|

Wastewater effluen tertiary

treatment|

Wastewater effluent |CAS $\mid$ SUVA $=3.04 \mathrm{~L} \mathrm{mg}^{-1} \mathrm{~m}^{-1}$

Wastewater effluent |MBR |

Wastewater effluent |CAS, ponds, dual media filtration

Wastewater effluent |CAS|

Wastewater effluent |CAS|

$\mathrm{DOC}=4.9-9.9 \mathrm{mg} \mathrm{L}^{-1}$

$\mathrm{DOC}=4.61 \mathrm{mg} \mathrm{L}^{-1}$ $3.04 \mathrm{~L} \mathrm{mg}^{-1} \mathrm{~m}^{-1}$

TOC $=11.1 \mathrm{mg} \mathrm{dm}^{-3}$

$\mathrm{COD}=2-37 \mathrm{mg} \mathrm{L}^{-1}$

$\mathrm{DOC}=5.90-14.36 \mathrm{mg} \mathrm{L}^{-1}$

$\mathrm{TOC}=26.7-44.4 \mathrm{mg} \mathrm{L}^{-1}$ SUVA $=2.5-3.3 \mathrm{~L} \mathrm{mg}^{-1} \mathrm{~m}^{-1}$ SUVA $=1.4 \mathrm{dm}^{3} \mathrm{mg}^{-1} \mathrm{~m}^{-1}$ SUVA $=1.82-2.71 \mathrm{~L} \mathrm{mg}^{-1} \mathrm{~m}^{-1}$ SUVA $=1.4-2.2 \mathrm{~L} \mathrm{mg}^{-1} \mathrm{~m}^{-1}$
Pre-treatment: GAC (0.015-2 g)

(pore size: $0.2 \mu \mathrm{m}$ ) UF (50,000 Da)

RO

UF $(10-15 \mathrm{kDa})$

e-treatment: coagulation $\left(\mathrm{FeCl}_{3}\right.$,

$\left.120 \mathrm{mg} \mathrm{L}^{-1}\right)$ and PAC $\left(40 \mathrm{mg} \mathrm{L}^{-1}\right)$

UF (pore size: $0.04 \mu \mathrm{m}$ )

MF (pore size: $0.2 \mu \mathrm{m}$ ) $\mathrm{UF}(50,000 \mathrm{Da})$

MF (pore size: $0.04 \mu \mathrm{m})$; NF (200 Da) RO (100 Da)

MF (pore size: $0.04 \mu \mathrm{m}$ ) UF (150 kDa) (1)atment: AER $\left(5 \mathrm{mg} \mathrm{L}^{-1}\right)$, PAC $\left(100 \mathrm{mg} \mathrm{L}^{-1}\right)$ and ozonation $\left(\mathrm{O}_{3} / \mathrm{DOC}=5.5\right)$

RO

F (pore size: $0.04 \mu \mathrm{m}$ )

Pre-treatment: UF, dual media filtration (sand and anthracite), GAC
COD $\mathrm{COmoval}_{\text {rel }}(\%) / \mathrm{UF}=70 ; \mathrm{FeCl}_{3}+\mathrm{UF}=87.9 ; \mathrm{PAC}+\mathrm{UF}=75.7$ $\mathrm{FCl}_{3}+\mathrm{PAC}+\mathrm{UF}=95.8$

- Coagulation and PAC reduced the membrane fouling.

The biopolymers fraction and the humic substances were found to contribute largely to the total fouling.

$\mathrm{COD}_{\text {removal }}(\%) / \mathrm{MF}=47 ; \mathrm{UF}=46$

- MF and UF resulted in same quality output of the treated water. From an economical point of view, MF offered superior advantages compared to UF.

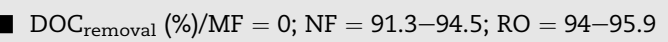

- High MW compounds (i.e. humic and fulvic acids) were entirely rejected by the $\mathrm{NF}$ and RO membranes.

- $40-50 \%$ of the remaining TOC in permeates consisted of low MW acids and neutrals representing an MW range of $\sim 500 \mathrm{Da}$.

- Biopolymers $_{\text {removal }}(\%) / \mathrm{MF}-\mathrm{UF}=82-89 ; \mathrm{AER}+\mathrm{MF}-\mathrm{UF}=68-71$ $\mathrm{PAC}+\mathrm{MF}-\mathrm{UF}=52-63 ;$ Ozonation $+\mathrm{MF}-\mathrm{UF}=6-14$

Abdessemed and Nezzal, 2002

Ayache et al. 2013

Alonso et al. 200

Drewes et al 2003

Humic compounds/building blocks removal $(\%) / \mathrm{MF}-\mathrm{UF}=12-16$

$\mathrm{AER}+\mathrm{MF}-\mathrm{UF}=4-5 ; \mathrm{PAC}+\mathrm{MF}-\mathrm{UF}=1-2 ;$ Ozonation $+\mathrm{MF}-\mathrm{UF}=0$

- Pre-treatment with AER and PAC did not improve the permeate flux rate for MF or UF in contrast to ozonation.

- The residual organic matter present in the RO permeate was mainly composed of hydrophilic substances.

- The adsorbable fraction remained almost constant $(20 \%)$ in the entire hydraulic range studied, corresponding to a steady removal of the hydrophobic fraction prone to adsorb on the membrane surface, ranging from $63 \%$ to $66 \%$

DOC ${ }_{\text {removal }}(\%) / 12-25 \%$

- The DOC removed comprised biopolymers (proteins, polysaccharides and colloidal organics).

- The colloidal fraction showed high flux decline and membrane fouling due to the pore blockage. The hydrophobic and transphilic fractions exhibited less fouling and flux decline than the colloids due to their molecular size as well as electrostatic repulsion between organic acids and the membrane surface.

- Proteins, polysaccharides and/or aminosugars were the main foulants.

- TOC $_{\text {removal }}(\%) / 75-90$

UF provided the best pre-treatment for RO resulting in high turbidity removal and low flux decline. The dual media filter and GAC did not
Filloux et al, $2012 b$

Gur-Reznik et al. 2008

Henderson et al., 2011

\section{arusutthirak}

et al., 2002 


\begin{tabular}{|c|c|c|c|c|}
\hline & & $\begin{array}{l}\text { and flocculation (polyacrylamide, } \\
15 \mathrm{mg} \mathrm{L}^{-1} \text { ) }\end{array}$ & $\begin{array}{l}\text { provide adequate pre-treatment; this led to rapid fouling in the RO } \\
\text { membrane. Flocculation did not significantly improve the performance of } \\
\text { the dual media filtration and the GAC. }\end{array}$ & \\
\hline $\begin{array}{l}\text { Wastewater effluent } \\
\text { |CAS, coagulation, } \\
\text { sand filtration| }\end{array}$ & $\begin{array}{l}\mathrm{DOC}=6.5 \mathrm{mg} \mathrm{L}^{-1} \\
\text { SUVA }=2.2 \mathrm{~L} \mathrm{mg}^{-1} \mathrm{~m}^{-1}\end{array}$ & $\begin{array}{l}\mathrm{NF}(200-400 \mathrm{Da}) \\
\text { Pre-treatment: ozonation } \\
\left(\mathrm{O}_{3} / \mathrm{DOC}=0.6-1\right) \text { and slow sand } \\
\text { filtration (sand size: } 0.4-0.8 \mathrm{~mm})\end{array}$ & $\begin{array}{l}\text { DOC } \\
\text { With the help of ozonation leading to breakdown of the large organic } \\
\text { molecules, slow sand filtration preferentially removed } \mathrm{SMPs} \text { and } \mathrm{dE}_{\mathrm{f}} \mathrm{OM} \\
\text { with } \mathrm{MW}<1 \mathrm{kDa} \text {. } \\
\text { NF removed humic acid-like }(72 \%) \text { and fulvic acid-like }(68 \%) \text { substances } \\
\text { efficiently and } \mathrm{dE}_{\mathrm{f}} \mathrm{OM} \text { with } \mathrm{MW}>1 \mathrm{kDa} \text {. }\end{array}$ & Linlin et al., 2011 \\
\hline $\begin{array}{l}\text { Wastewater effluent } \\
\text { |CAS } \mid\end{array}$ & $\mathrm{TOC}=6.5-10.4 \mathrm{mg} \mathrm{L}^{-1}$ & $\begin{array}{l}\mathrm{NF}(200,250,700 \mathrm{Da}) \\
\text { Pre-treatment: flocculation }\left(\mathrm{FeCl}_{3}\right) \text { and } \\
\text { PAC }\end{array}$ & $\begin{array}{l}\text { TOC } \mathrm{T}_{\text {removal }}(\%) / \mathrm{NF}_{(700 \mathrm{Da})}=77 ; \mathrm{NF}_{(700 \mathrm{Da})+\text { pre-treatment }}=92 \\
\mathrm{TOC}_{\text {removal }}(\%) / \mathrm{NF}_{(200,250 \mathrm{Da})}>92 \\
\text { (with and without pre-treatment) } \\
\text { TOC removal efficiency increased by } 15 \% \text { by the pre-treatment when NF } \\
(700 \mathrm{Da}) \text { was used. When the other two membranes were used ( } 200 \text { and } \\
250 \mathrm{Da}) \text {, the TOC removal efficiency did not increase from that without pre- } \\
\text { treatment. } \\
\text { The detected functional groups in the deposit on the membrane without } \\
\text { any pre-treatment was alkene (NF: } 700 \mathrm{Da}) \text {, urea (NF: } 250 \mathrm{Da}) \text {, keton } \\
\text { functional groups (NF: } 200 \mathrm{Da}) \text {. The functional groups responsible for } \\
\text { membrane fouling were removed by the pre-treatment. }\end{array}$ & Shon et al., 2003 \\
\hline $\begin{array}{l}\text { Wastewater effluent } \\
\qquad \text { CAS } \mid\end{array}$ & $\begin{array}{l}\text { TOC }=6.6 \mathrm{mg} \mathrm{L}^{-1} \\
\mathrm{SUVA}=1.661 \mathrm{~L} \mathrm{mg}^{-1} \mathrm{~m}^{-1}\end{array}$ & $\begin{array}{l}\mathrm{UF}(17,500 \mathrm{Da}) \\
\text { Pre-treatment: flocculation } \\
\left(\mathrm{FeCl}_{3}, 120 \mathrm{mg} \mathrm{L}^{-1}\right) \text { and PAC }\left(1 \mathrm{~g} \mathrm{~L}^{-1}\right)\end{array}$ & $\begin{array}{l}\text { TOC } \\
\mathrm{SUVA}_{\text {removal }}(\%) / \mathrm{UF}_{\text {(without pre-treatment) }}=43.6 ; \mathrm{UF} \text { (without pre-treatment) }=25.5 \text {; } \\
\mathrm{UF}_{\text {(with pre-treatment) }}=61.4 \\
\text { The highest remove-treatment) }=91 \\
\text { followed by adsorption was used as pre-treatment. } \\
\text { The pretreatment led to practically no filtration flux decline. }\end{array}$ & Shon et al., 2004 \\
\hline $\begin{array}{l}\text { Wastewater effluent } \\
\text { |CAS } \mid\end{array}$ & $\mathrm{TOC}=6.5-10.4 \mathrm{mg} \mathrm{L}^{-1}$ & UF $(17,500 \mathrm{Da})$ & $\begin{array}{l}\text { Removal }(\%) / \text { Hydrophobic }=67.4 \text {; transphilic }=52.9 \text {; hydrophilic }=19.7 \\
\text { The flux decline caused by the hydrophobic fraction was very high. }\end{array}$ & Shon et al., $2006 c$ \\
\hline $\begin{array}{l}\text { Wastewater effluent } \\
\qquad \text { CAS } \mid\end{array}$ & $\begin{array}{l}\mathrm{DOC}=4.9 \mathrm{mg} \mathrm{L}^{-1} \\
\text { SUVA }=2.6 \mathrm{~L} \mathrm{mg}^{-1} \mathrm{~m}^{-1}\end{array}$ & UF (150 kDa) & $\begin{array}{l}\text { - } \begin{array}{l}\mathrm{DOC}_{\text {removal }}(\%) / 94 \\
\text { Biopolymers have been demonstrated to play a core role in fouling } \\
\text { phenomena }\end{array}\end{array}$ & Zheng et al., 2014 \\
\hline \multicolumn{5}{|c|}{ Activated carbon/anion-exchange resin } \\
\hline $\begin{array}{l}\text { Wastewater effluent } \\
\text { |primary } \\
\text { treatment } \mid\end{array}$ & $\mathrm{COD}=165 \mathrm{mg} \mathrm{L}^{-1}$ & $\begin{array}{l}\text { PAC }\left(40 \mathrm{mg} \mathrm{L}^{-1}\right) \\
\text { Pre-treatment: coagulation } \\
\left(\mathrm{FeCl}_{3}, 120 \mathrm{mg} \mathrm{L}^{-1}\right)\end{array}$ & - $\mathrm{COD}_{\text {removal }}(\%) / \mathrm{FeCl}_{3}=75.8 ; \mathrm{FeCl}_{3}+\mathrm{PAC}=87.9$ & $\begin{array}{l}\text { Abdessemed and } \\
\text { Nezzal, } 2002\end{array}$ \\
\hline $\begin{array}{l}\text { Wastewater effluent } \\
\text { |CAS } \mid\end{array}$ & $\begin{array}{l}\mathrm{DOC}=6.8 \mathrm{mg} \mathrm{L}^{-1} \\
\mathrm{SUVA}=3.04 \mathrm{~L} \mathrm{mg}^{-1} \mathrm{~m}^{-1}\end{array}$ & $\begin{array}{l}\text { PAC }\left(100 \mathrm{mg} \mathrm{L}^{-1}\right) \text {; } \\
\text { AER }\left(5 \mathrm{~mL} \mathrm{~L}^{-1}\right)\end{array}$ & $\begin{array}{l}\text { TOC } \text { removal }(\%) / \mathrm{PAC}=68-71 ; \mathrm{AER}=51-53 \\
\mathrm{UV}_{25 \mathrm{rremova}}(\%) / \mathrm{PAC}=79 ; \mathrm{AER}=71 \\
\text { The AER treatment preferentially removed high and intermediate MW } \\
\text { humic-like substances, while PAC removed the majority of low MW } \\
\text { compounds. Only a small reduction of the high MW colloids (i.e. } \\
\text { biopolymers) was observed for AER and PAC treatments. }\end{array}$ & $\begin{array}{l}\text { Filloux et al., } \\
2012 b\end{array}$ \\
\hline $\begin{array}{l}\text { Wastewater effluent } \\
\text { |MBR } \mid\end{array}$ & $\begin{array}{l}\text { TOC }=11.1 \mathrm{mg} \mathrm{dm}^{-3} \\
\text { SUVA }=1.4 \mathrm{dm}^{3} \mathrm{mg}^{-1} \mathrm{~m}^{-1}\end{array}$ & GAC & - $\mathrm{DOC}_{\text {removal }}(\%) /$ hydrophobic $=66 ;$ hydrophilic $=83 ;$ transphilic $=83$ & $\begin{array}{l}\text { Gur-Reznik et al., } \\
2008\end{array}$ \\
\hline
\end{tabular}




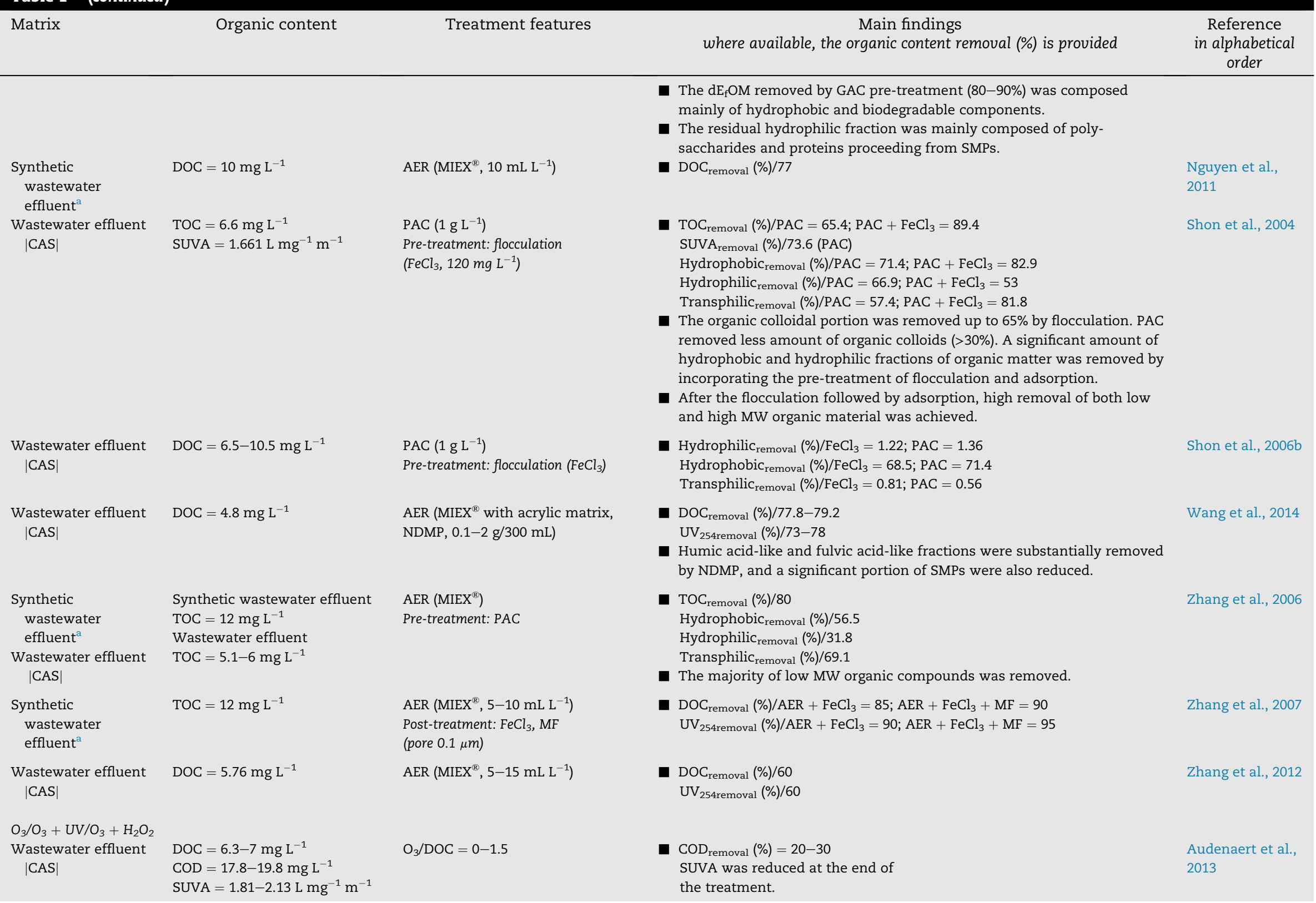

The $\mathrm{dE}_{\mathrm{f}} \mathrm{OM}$ removed by GAC pre-treatment (80-90\%) was composed mainly of hydrophobic and biodegradable components.

saccharides and proteins proceeding from SMPs.

Synthetic

effluent

astewater effluent

$\mathrm{OC}=6.6 \mathrm{mg} \mathrm{L}^{-1}$

tent: flocculation

$\left(\mathrm{FeCl}_{3}, 120 \mathrm{mg} \mathrm{L}^{-1}\right)$

the treatment. $\left(1 \mathrm{~L}^{-1}\right)$

ER (MIEX ${ }^{\circledR}$ with acrylic matrix, DMP, $0.1-2 \mathrm{~g} / 300 \mathrm{~mL}$

rial was achieved.

drophobic $(\%) / \mathrm{FeCl}_{3}=68.5 ; \mathrm{PAC}=71.4$

by NDMP, and a significant portion of SMPs were also reduced.

(\%)/56.5

$\mathrm{DOC}_{\text {remolal }}(\%) / \mathrm{AER}+\mathrm{FeCl}_{3}=85 ; \mathrm{AER}+\mathrm{FeCl}_{3}+\mathrm{MF}=90$

(pore $0.1 \mu \mathrm{m}$ ) 
Wastewater effluent $|\mathrm{CAS}+\mathrm{MBR}|$

$\mathrm{OC}=6.2-11.5 \mathrm{mg} \mathrm{L}^{-1}$ SUVA $=1.8-2.4 \mathrm{~L} \mathrm{mg}^{-1} \mathrm{~m}^{-1}$

$\mathrm{DOC}=6.8 \mathrm{mg} \mathrm{L}^{-1}$

SUVA $=3.04 \mathrm{~L} \mathrm{mg}^{-1} \mathrm{~m}^{-1}$

CAS

$\left[\mathrm{O}_{3}\right]=37 \mathrm{mg} \mathrm{L}^{-1} ; \mathrm{O}_{3} / \mathrm{DOC}=5.5$
Wastewater effluent |CAS $\mid$

Wastewater effluent |CAS|

Wastewater

effluents $|\mathrm{CAS}|$

Wastewater effluent |CAS, coagulation, sand filtration|

Wastewater effluent |CAS|
$\mathrm{DOC}=8.18-21.7 \mathrm{mg} \mathrm{L}^{-1}$ $\mathrm{UV}_{254}=0.182-0.280 \mathrm{~cm}^{-1}$

DOC $=5.5-11.7 \mathrm{mg} \mathrm{L}^{-1}$ SUVA $=1.43-2.14 \mathrm{~L} \mathrm{mg}^{-1} \mathrm{~m}^{-1}$

$\mathrm{DOC}=5.623 \mathrm{mg} \mathrm{L}^{-1}$ SUVA $=0.021 \mathrm{~L} \mathrm{mg}^{-1} \mathrm{~m}^{-1}$

$\mathrm{DOC}=6.5 \mathrm{mg} \mathrm{L}^{-1}$ SUVA $=2.2 \mathrm{~L} \mathrm{mg}^{-1} \mathrm{~m}^{-1}$

$\mathrm{TOC}=6.6-8.6 \mathrm{mg} \mathrm{L}^{-1}$ $\mathrm{COD}=59-60 \mathrm{mg} \mathrm{L}^{-1}$ $\mathrm{BOD}_{5}=7.3-12.7 \mathrm{mg} \mathrm{L}^{-1}$
$\left[\mathrm{O}_{3}\right]_{\text {gas }}=12 \mathrm{~g} \mathrm{~m}^{-3} ; \mathrm{H}_{2} \mathrm{O}_{2} / \mathrm{O}_{3}=0.35$

- At the end of the experiments, most of the DOC was hydrophilic in nature and the very hydrophobic acid fraction was almost completely removed.

DOC $C_{\text {removal }}(\%) / \mathrm{O}_{3}=12-48 ; \mathrm{O}_{3}+\mathrm{H}_{2} \mathrm{O}_{2}=14-60$

$\mathrm{COD}_{\text {removal }}(\%) / \mathrm{O}_{3}=44-55$;

$\mathrm{O}_{3}+\mathrm{H}_{2} \mathrm{O}_{2}=48-100$

$\mathrm{UV}_{254 \text { removal }}(\%) / \mathrm{O}_{3}=38-61$

TOC $_{\text {removal }}(\%) /(-13)-(-8)^{*}$

$\mathrm{UV}_{254 \text { removal }}(\%) / 84$

- Ozonation modified the MW distribution of $\mathrm{dE}_{\mathrm{f}} \mathrm{OM}$ by breaking large

organic molecules and increasing their biodegradability.

- Ozonation induced a large reduction of the biopolymers (44\%) and an

important increase of the low MW humic substances (i.e. building blocks). *The slight increase in TOC after ozonation can be explained as ozonation may have oxidized particulate organic carbon (i.e. sample pre-filtered through $10 \mathrm{~mm}$ ) and converted it into dissolved organic matter.

$\left[\mathrm{O}_{3}\right]=9.1 \mathrm{mg} \mathrm{L}^{-1} ; \mathrm{UV}$ (low-pressure lamp, $\lambda=254 \mathrm{~nm}, 25 \mathrm{~W}$,

$4700 \mu \mathrm{W} \mathrm{cm}{ }^{-2}$ ); contact

time $=150 \mathrm{~min}$

$\mathrm{O}_{3} / \mathrm{DOC}=1$

$\left.\mathrm{O}_{3}\right]=4 \mathrm{mg} \mathrm{L}^{-1} ;\left[\mathrm{FeCl}_{3}\right]=2.5 \mathrm{mg} \mathrm{L}^{-1}$ UF

$\mathrm{DOC}_{\text {removal }}(\%) / \mathrm{O}_{3}=28^{*} ; \mathrm{O}_{3}+\mathrm{UV}=88$

$\mathrm{UV}_{254 \text { removal }}(\%) / \mathrm{O}_{3}=72 ; \mathrm{O}_{3}+\mathrm{UV}=85$

*The values are not reported by the authors in the cited study. They were calculated from the figures in the study.

- $\mathrm{O}_{3}$ reacted sequentially with aromatic hydrophobic, transphilic, and the hydrophilic fractions; however, under UV, it reacted with all four organic fractions simultaneously.

- Low MW hydrophilic compounds (e.g. aliphatic, carboxylic, acetic and formic acid) were detected in the treated effluent ( $M W<1000 \mathrm{Da})$.

- The fractions of $\mathrm{dE}_{\mathrm{f}} \mathrm{OM}$ with $\mathrm{MW}<10 \mathrm{kDa}$ had a higher reactivity to $\mathrm{O}_{3}$ compared to the components with $\mathrm{MW}>10 \mathrm{kDa}$.

DOC removal $_{(\%) / 17.63}$

SUVA removal $(\%) / 33.3$

- The reduction of the UF membrane flux decline was due to the significan decrease of high MW fraction ( $>5 \mathrm{kDa}$ ) by ozone along with coagulation,

resulting in the formation of low MW, highly charged compounds.

DOC removal $(\%) / 1.5$

SUVA $_{\text {removal }}(\%) / 63.6$

Ozonation exhibited no significant DOC reduction.

- Ozonation decreased significantly fulvic acid-like (75\%), humic acid-like (76\%) and tryptophan protein-like (77\%) substances.

- $\mathrm{dE}_{\mathrm{f}} \mathrm{OM}$ fraction with $\mathrm{MW}$ above $1 \mathrm{kDa}$ was efficiently removed.

$\left[\mathrm{O}_{3}\right]=0-0.3 \mathrm{mM} ; \mathrm{H}_{2} \mathrm{O}_{2} / \mathrm{O}_{3}<0.5$

- $\mathrm{TOC}_{\text {removal }}(\%) / \mathrm{O}_{3}<35 ; \mathrm{O}_{3}+\mathrm{H}_{2} \mathrm{O}_{2}=75-100$

- The evolution of TOC was related to the concentration of HO following a second-order kinetic model.

- The results showed that the mineralization process took place in two

periods whose rate constants were linked to the COD/BOD ratio and to the chloride content.

Domenjoud et al. 2011

Filloux et al.

$2012 b$

Gong et al., 2008 


\begin{tabular}{|c|c|c|c|c|}
\hline Matrix & Organic content & Treatment features & $\begin{array}{l}\text { Main findings } \\
\text { where available, the organic content removal (\%) is provided }\end{array}$ & $\begin{array}{l}\text { Reference } \\
\text { in alphabetical } \\
\text { order }\end{array}$ \\
\hline $\begin{array}{l}\text { Wastewater effluent } \\
\text { |CAS, coagulation, } \\
\text { filtration| }\end{array}$ & $\begin{array}{l}\text { TOC }=6.7 \mathrm{mg} \mathrm{L}^{-1} \\
\mathrm{SUVA}=1.7 \mathrm{~L} \mathrm{mg}^{-1} \mathrm{~m}^{-1}\end{array}$ & $\begin{array}{l}{\left[\mathrm{O}_{3}\right]=0.9-11.6 \mathrm{mg} \mathrm{L}^{-1} ; \text { contact }} \\
\text { time }=30 \mathrm{~min}\end{array}$ & $\begin{array}{l}\text { - } \mathrm{TOC}_{\text {removal }}(\%) / 10 \\
\mathrm{SUVA}_{\text {removal }}(\%) / 58 \\
\text { Ozonation decreased the hydrophobic fraction of } \mathrm{dE}_{\mathrm{f}} \mathrm{OM} \text {. } \\
\text { A shift was observed from high } \mathrm{MW} \text { to low } \mathrm{MW} \text { after treatment. } \\
\text { The second-order reaction rate constant between } \mathrm{dE}_{\mathrm{f}} \mathrm{OM} \text { and } \mathrm{HO} \text {. } \\
\text { remained constant throughout the process. }\end{array}$ & $\begin{array}{l}\text { Rosario-Ortiz } \\
\text { et al., 2008b }\end{array}$ \\
\hline $\begin{array}{l}\text { Wastewater effluent } \\
\text { |CAS, MBR | }\end{array}$ & $\begin{array}{l}\mathrm{DOC}=4.31-8.6 \mathrm{mg} \mathrm{L}^{-1} \\
\mathrm{COD}=12-24 \mathrm{mg} \mathrm{L}^{-1}\end{array}$ & $\mathrm{O}_{3} / \mathrm{DOC}=0.5$ & $\begin{array}{l}\text { - } \mathrm{COD}_{\text {removal }}(\%) / 15-45 \\
\mathrm{UV}_{254 \text { removal }}(\%) / 60\end{array}$ & Sharif et al., 2012 \\
\hline $\begin{array}{l}\mathrm{UV} / \mathrm{UV}+\mathrm{H}_{2} \mathrm{O}_{2} \\
\text { Wastewater effluent } \\
\text { |CAS } \mid\end{array}$ & $\begin{array}{l}\mathrm{DOC}=6.3-7 \mathrm{mg} \mathrm{L}^{-1} \\
\mathrm{COD}=17.8-19.8 \mathrm{mg} \mathrm{L}^{-1} \\
\text { SUVA }=1.81-2.13 \mathrm{~L} \mathrm{mg}^{-1} \mathrm{~m}^{-1}\end{array}$ & $\begin{array}{l}\text { UV (low-pressure lamp, } 11 \mathrm{~W} \\
\lambda=254 \mathrm{~nm}) ;\left[\mathrm{H}_{2} \mathrm{O}_{2}\right]=2-4 \mathrm{mM}\end{array}$ & $\begin{array}{l}\text { - } \mathrm{COD}_{\text {removal }}(\%) / 20-30 \\
\text { SUVA was reduced at the end of the treatment, while at the end of the } \\
\text { experiments, most of the DOC was hydrophilic in nature. }\end{array}$ & $\begin{array}{l}\text { Audenaert et al., } \\
2013\end{array}$ \\
\hline $\begin{array}{l}\text { Wastewater effluent } \\
\text { |CAS, MBR | }\end{array}$ & $\begin{array}{l}\mathrm{DOC}=6.3-15.2 \mathrm{mg} \mathrm{L}^{-1} \\
\mathrm{TOC}=6.8-17.4 \mathrm{mg} \mathrm{L}^{-1} \\
\mathrm{UV}_{254}=16.3-30.3 \mathrm{~m}^{-1}\end{array}$ & $\begin{array}{l}\text { UV (low-pressure lamp, } 8 \mathrm{~W} \\
\lambda=254 \mathrm{~nm}) ;\left[\mathrm{H}_{2} \mathrm{O}_{2}\right]=2.94 \mathrm{mM}\end{array}$ & $\begin{array}{l}\text { TOC } \text { Tremoval }_{\text {(\%)/CAS: } 47.9, \text { MBR: } 47.8} \\
\text { SUVA }_{\text {removal }}(\%) / 60-63 \\
\text { Residual } \mathrm{dE}_{\mathrm{f}} \mathrm{OM} \text { (CAS): } 74.1 \% \text { LMM compounds ( } 16.0 \% \text { acids, } 27.1 \% \text { building } \\
\text { blocks and } 31 \% \text { neutrals) and } 25.9 \% \text { high MW compounds ( } 19.6 \% \text { humic } \\
\text { substances). } \\
\text { Residual dEfOM (MBR): } 0.8 \% \text { biopolymers, } 11.7 \% \text { humic substances, } 24.0 \% \\
\text { LMM neutrals, } 14.9 \% \text { LMM acids and } 48.6 \% \text { building blocks. }\end{array}$ & $\begin{array}{l}\text { González et al., } \\
2013\end{array}$ \\
\hline $\begin{array}{l}\text { Wastewater effluent } \\
\text { |CAS } \mid\end{array}$ & $\begin{array}{l}\mathrm{DOC}=15.5 \mathrm{mg} \mathrm{L}^{-1} \\
\mathrm{UV}_{254}=0.314 \mathrm{~cm}^{-1}\end{array}$ & $\begin{array}{l}\text { UV (low-pressure lamp, } 8 \mathrm{~W} \\
\lambda=254 \mathrm{~nm}) ;\left[\mathrm{H}_{2} \mathrm{O}_{2}\right]=5 \mathrm{mg} \mathrm{L}^{-1} \\
\mathrm{H}_{2} \mathrm{O}_{2} / \mathrm{DOC}=0.1\end{array}$ & $\begin{array}{l}\text { - } \mathrm{DOC}_{\text {removal }}(\%) / 19 \\
\mathrm{UV}_{254 \text { removal }}(\%) / 97\end{array}$ & Souza et al., 2014 \\
\hline $\begin{array}{l}\text { Wastewater effluent } \\
\text { |CAS, UF/RO } \mid\end{array}$ & $\begin{array}{l}\mathrm{DOC}=32-37 \mathrm{mg} \mathrm{L}^{-1} \\
\mathrm{UV}_{254}=0.68 \mathrm{~cm}^{-1}\end{array}$ & $\begin{array}{l}\text { LED }(0.33 \mathrm{~mW} \text { each, } \lambda=255 \mathrm{~nm}) \\
{\left[\mathrm{H}_{2} \mathrm{O}_{2}\right]=3 \mathrm{mmol} \mathrm{L}} \\
\text { Pre-treatment: } \mathrm{Al}^{-1} \\
\text { Post-treatment: biodegradable } \\
\text { dissolved organic carbon assay (BDOC) }\end{array}$ & $\begin{array}{l}\text { DOC } \text { removal }(\%) / \mathrm{LED}+\mathrm{H}_{2} \mathrm{O}_{2}=37 ; \mathrm{LED}+\mathrm{H}_{2} \mathrm{O}_{2}+\mathrm{Al}^{3+}=52 \text {, } \\
\mathrm{LED}+\mathrm{H}_{2} \mathrm{O}_{2}+\mathrm{Al}^{3+}+\mathrm{BDOC}=67 \\
\text { LED }+\mathrm{H}_{2} \mathrm{O}_{2} \text { treatment increased the biodegradability of the effluents. } \\
\text { Alum coagulation pre-treatment led to complementary effect on DOC } \\
\text { removal. }\end{array}$ & Umar et al., 2015 \\
\hline $\begin{array}{l}\text { Wastewater effluent } \\
\qquad \text { CAS } \mid\end{array}$ & $\begin{array}{l}\mathrm{DOC}=12.8 \mathrm{mg} \mathrm{L}^{-1} \\
\mathrm{UV}_{254}=0.38 \mathrm{~cm}^{-1}\end{array}$ & $\begin{array}{l}\text { UV-C }(39 \mathrm{~W}, \lambda=254 \mathrm{~nm}) \text {; VUV } \\
(46 \mathrm{~W}, \lambda=185 \mathrm{~nm}) \\
{\left[\mathrm{H}_{2} \mathrm{O}_{2}\right]=32 \mathrm{mg} \mathrm{L}^{-1}}\end{array}$ & $\begin{array}{l}\text { DOC } \mathrm{DOmoval}_{\text {remol }}\left(\% \mathrm{UV}-\mathrm{C}+\mathrm{H}_{2} \mathrm{O}_{2}=20 ; \mathrm{VUV}+\mathrm{H}_{2} \mathrm{O}_{2}=10\right. \\
\mathrm{UV}_{254 \text { removal }}(\%) / \mathrm{UV}-\mathrm{C}+\mathrm{H}_{2} \mathrm{O}_{2}=75 ; \mathrm{VUV}+\mathrm{H}_{2} \mathrm{O}_{2}=43\end{array}$ & $\begin{array}{l}\text { Puspita et al., } \\
2015\end{array}$ \\
\hline \multicolumn{5}{|l|}{ Fenton/Photo-Fenton } \\
\hline $\begin{array}{l}\text { Wastewater effluent } \\
\quad \mid \text { CAS } \mid\end{array}$ & $\mathrm{DOC}=9.6 \mathrm{mg} \mathrm{L}^{-1}$ & $\begin{array}{l}{\left[\mathrm{Fe}^{2+}\right]=10 \mathrm{mg} \mathrm{L}^{-1} ; \mathrm{H}_{2} \mathrm{O}_{2}: \mathrm{Fe}^{2+}=2.5} \\
\mathrm{pH}=3\end{array}$ & $\begin{array}{l}\text { DOC }{ }_{\text {removal }}(\%) / 30 \\
\mathrm{dE}_{\mathrm{f}} \mathrm{OM} \text { was oxidized yielding formate, acetate, oxalate and, less } \\
\text { prominently, formaldehyde, acetaldehyde, propionaldehyde and } \\
\text { glycolaldehyde. } \\
\text { Fenton oxidation decreased the absorbance of wastewater at all } \\
\text { wavelengths }>240 \mathrm{~nm} \text {. } \\
\text { High MW molecules were degraded. }\end{array}$ & Li et al., 2012 \\
\hline $\begin{array}{l}\text { Wastewater effluent } \\
\quad \mid \text { CAS } \mid\end{array}$ & $\mathrm{DOC}=8.1-11.8 \mathrm{mg} \mathrm{L}^{-1}$ & $\begin{array}{l}{\left[\mathrm{Fe}^{2+}\right]=5-10 \mathrm{mg} \mathrm{L}^{-1}} \\
\mathrm{H}_{2} \mathrm{O}_{2}: \mathrm{Fe}^{2+}\left(\text { or } \mathrm{Fe}^{3+}\right)=2.5 ; \mathrm{pH}=3 \\
\text { Fenton-like refers to the use of } \mathrm{Fe}^{3+}\end{array}$ & $\begin{array}{l}\text { DOC } \mathrm{DOmoval}_{\text {rem }}(\%) / \text { Fenton }=38(30 \mathrm{~min}) ; \text { Fenton-like }=43(120 \mathrm{~min}) \\
\text { Both Fenton and Fenton-like caused a consistent decrease of } \mathrm{dE}_{\mathrm{f}} \mathrm{OM} \\
\text { fluorescence regions (humic-like; fulvic-like and protein-like/soluble } \\
\text { microbial products). }\end{array}$ & Li et al., 2013 \\
\hline
\end{tabular}




\begin{tabular}{|c|c|c|c|c|}
\hline $\begin{array}{l}\text { Wastewater effluent } \\
\qquad \text { CAS } \mid\end{array}$ & $\begin{array}{l}\mathrm{DOC}=6.29-8.60 \mathrm{mg} \mathrm{L}^{-1} \\
\mathrm{COD}=25-27 \mathrm{mg} \mathrm{L}^{-1}\end{array}$ & $\begin{array}{l}{\left[\mathrm{Fe}^{2+}\right]=5 \mathrm{mg} \mathrm{L}^{-1} ;} \\
{\left[\mathrm{H}_{2} \mathrm{O}_{2}\right]=75 \mathrm{mg} \mathrm{L}^{-1} ; \text { pilot scale }} \\
\text { (CPC); natural sunlight; } \mathrm{pH}=3\end{array}$ & $\begin{array}{l}\text { Protein-like and SMPs were completely removed. } \\
\text { DOC }{ }_{\text {removal }}(\%) / 21 \\
\mathrm{COD}_{\text {removal }}(\%) / 50\end{array}$ & $\begin{array}{l}\text { Michael et al., } \\
2012 b\end{array}$ \\
\hline $\begin{array}{l}\text { Synthetic } \\
\text { wastewater } \\
\text { effluent }^{a}\end{array}$ & $\begin{array}{l}\text { Synthetic wastewater effluent } \\
\text { DOC }=20-30 \mathrm{mg} \mathrm{L}^{-1} \\
\text { Wastewater effluent }\end{array}$ & $\begin{array}{l}{\left[\mathrm{Fe}^{2+}\right]=2.5-10 \mathrm{mg} \mathrm{L}^{-1}} \\
{\left[\mathrm{H}_{2} \mathrm{O}_{2}\right]=5-50 \mathrm{mg} \mathrm{L}^{-1} ;} \\
\text { pilot scale (CPC); natural sunlight; }\end{array}$ & - $\mathrm{DOC}_{\text {removal }}(\%) / \mathrm{pH}$ 5: 19-22; pH 3: $28-70$ & $\begin{array}{l}\text { Rodríguez- } \\
\text { Chueca et al., } \\
2014\end{array}$ \\
\hline $\begin{array}{l}\text { Wastewater effluent } \\
\quad|\mathrm{CAS}| \\
\mathrm{TiO}_{2}-\mathrm{UV}\end{array}$ & $\mathrm{DOC}=17 \mathrm{mg} \mathrm{L}^{-1}$ & $\mathrm{pH}=3$ and 5 & & \\
\hline $\begin{array}{l}\text { Wastewater effluent } \\
\text { |CAS, dual media } \\
\text { filtration| }\end{array}$ & na & $\begin{array}{l}\text { UV (low-pressure lamp, } 75 \mathrm{~W} \\
\lambda=254 \mathrm{~nm} \text { ) }\end{array}$ & - $\mathrm{COD}_{\text {removal }}(\%) / 50$ & Al-Bastaki, 2004 \\
\hline $\begin{array}{l}\text { Synthetic } \\
\text { wastewater } \\
\text { effluent }^{2}\end{array}$ & na & $\begin{array}{l}\mathrm{TiO}_{2} \text { (Degussa P25); } \\
{\left[\mathrm{TiO}_{2}\right]=0.1-10 \mathrm{~g} \mathrm{~L}^{-1} \text {; UV-A }(8 \mathrm{~W})} \\
\text { Pre-treatment: } \\
\left(\mathrm{FeCl}_{3}, 10-120 \mathrm{mg} \mathrm{L}^{-1}\right) \text { and } \\
\mathrm{PAC}\left(0.1-5 \mathrm{~g} \mathrm{~L}^{-1}\right)\end{array}$ & $\begin{array}{l}\text { The } \mathrm{TiO}_{2} \text { photocatalysis alone showed initial reverse reaction (i.e. } \mathrm{DOC} \\
\text { increased with time). } \\
\text { PAC adsorption followed by photocatalysis was not effective in alleviating } \\
\text { reverse reaction (high } \mathrm{MW} \mathrm{dE}_{\mathrm{f}} \mathrm{OM} \text { remained in the solution after the PAC } \\
\text { adsorption was adsorbed on the } \mathrm{TiO}_{2} \text { surface and was broken down into } \\
\text { low } \mathrm{MW} \mathrm{dE}_{\mathrm{f}} \mathrm{OM} \text {, thus increasing the organic concentration). } \\
\text { When } \mathrm{PAC} \text { and } \mathrm{TiO}_{2} \text { were added simultaneously, the reverse reaction was } \\
\text { eliminated. } \\
\text { When flocculation was used as pretreatment to photocatalysis, the organic } \\
\text { removal efficiency was superior. }\end{array}$ & Shon et al., 2005 \\
\hline $\begin{array}{l}\text { Wastewater effluent } \\
\mid \text { CAS } \mid\end{array}$ & $\mathrm{DOC}=6.5 \mathrm{mg} \mathrm{L}^{-1}$ & $\begin{array}{l}\mathrm{TiO}_{2} \text { (Degussa P25); }\left[\mathrm{TiO}_{2}\right]=2 \mathrm{~g} \mathrm{~L}^{-1} \\
\mathrm{UV}-\mathrm{C}(8 \mathrm{~W}, \lambda=253 \mathrm{~nm}) \\
\mathrm{UV}-\mathrm{C}(15 \mathrm{~W}, \lambda=235 \mathrm{~nm}) \\
\text { UV-A }(15 \mathrm{~W}, \lambda=315-400 \mathrm{~nm}) \\
\text { Pre-treatment: flocculation }\left(\mathrm{FeCl}_{3}\right. \\
\left.69 \mathrm{mg} \mathrm{L}^{-1}\right) \text { and PAC }\left(0.5 \mathrm{~g} \mathrm{~L}^{-1}\right)\end{array}$ & $\begin{array}{l}\text { - } \mathrm{DOC}_{\text {removal }}(\%) / \mathrm{UV}-\mathrm{C}=70 ; \mathrm{UV}-\mathrm{A}=40 ; \mathrm{FeCl}_{3}+\mathrm{TiO}_{2}=92.1 ; \mathrm{PAC}+\mathrm{TiO}_{2}=77.5 \\
\text { Hydrophilic and transphilic fractions were removed by } 80 \% \text {. }\end{array}$ & Shon et al., 2007 \\
\hline $\begin{array}{l}\text { Synthetic } \\
\text { wastewater }^{\text {effluent }}{ }^{\mathrm{a}}\end{array}$ & $\mathrm{DOC}=10.5-11.5 \mathrm{mg} \mathrm{L}^{-1}$ & $\begin{array}{l}\mathrm{TiO}_{2} \text { (Degussa P25); }\left[\mathrm{TiO}_{2}\right]=1 \mathrm{~g} \mathrm{~L}^{-1} \text {; } \\
\mathrm{UV}(8 \mathrm{~W}, \lambda=253.7 \mathrm{~nm}) ; \mathrm{MF} / \mathrm{UF} \\
\text { Pre-treatment: flocculation }\left(\mathrm{AlCl}_{3} \text {, }\right. \\
\left.12 \mathrm{mg} \mathrm{L}^{-1}\right) \text { and PAC }\left(0.05 \mathrm{~g} \mathrm{~L}^{-1}\right)\end{array}$ & - $\mathrm{DOC}_{\text {removal }}(\%) / \mathrm{TiO}_{2}=70 ; \mathrm{TiO}_{2}+\mathrm{PAC}=76 ; \mathrm{TiO}_{2}+\mathrm{PAC}+\mathrm{AlCl}_{3}+\mathrm{MF} / \mathrm{UF}=92$ & Erdei et al., 2008 \\
\hline $\begin{array}{l}\text { Synthetic } \\
\text { wastewater } \\
\text { effluent }^{\mathrm{a}}\end{array}$ & $\mathrm{DOC}=10-11 \mathrm{mg} \mathrm{L}^{-1}$ & $\begin{array}{l}\mathrm{TiO}_{2} \text { (Degussa P25); }\left[\mathrm{TiO}_{2}\right]=0 \\
-1.5 \mathrm{~g} \mathrm{~L}^{-1} ; \mathrm{UV}(\lambda=352 \mathrm{~nm}) ; \mathrm{MF} \\
\text { (pore size }=0.1 \mu \mathrm{m})\end{array}$ & - $\mathrm{DOC}_{\text {removal }}(\%) / \mathrm{TiO}_{2}=40-62 ; \mathrm{TiO}_{2}+\mathrm{MF}=70-75$ & Ho et al., 2010 \\
\hline \multicolumn{5}{|c|}{$\begin{array}{l}\text { Abbreviations (given in alphabetical order) } \rightarrow \text { AER: anion-exchange resin; CAS: conventional activated sludge; COD: chemical oxygen demand; } \mathrm{dE}_{\mathrm{f}} \mathrm{OM} \text { : dissolved effluent organic matter; } \mathrm{DOC} \text { : dis- } \\
\text { solved organic carbon; GAC: granular activated carbon; LMM: low molar mass; MBR: membrane bioreactor; MF: microfiltration; MW: molecular weight; NF: nanofiltration; PAC: powdered activated } \\
\text { carbon; PACl: polyaluminum chloride; RO: reverse osmosis; SMPs: soluble microbial products; SUVA: specific ultraviolet absorbance (SUVA=UV254 } \times 100 / D O C) \text {; TOC: total organic carbon; UF: ultra- } \\
\text { filtration; UV } 254 \text { : ultraviolet absorbance at a wavelength of } 254 \mathrm{~nm} \text {. } \\
\text { na: Not available. } \\
\text { a } \text { The synthetic wastewater effluents used in the cited studies approximate the effluent organic matter generally found in biologically treated wastewater effluents. }\end{array}$} \\
\hline
\end{tabular}

The removal of fluorescence intensity by Fenton was fast during the first 30 min of tre tact times, while changes of the fluorescence intensity in Fenton-like

oxidations were much slower.

(CPC); natural sunlight; $\mathrm{pH}=$

pilot scale (CPC); natural sunlight

DOC $=20-30 \mathrm{mg} \mathrm{L}^{-1}$

Wastewater effluen

$\mathrm{pH}=3$ and 5

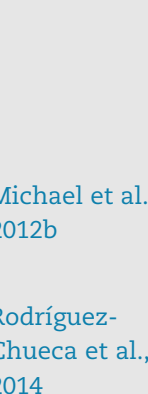

UV-C ( $8 \mathrm{~W}, \lambda=253 \mathrm{~nm})$;
UV-C $(15 \mathrm{~W}, \lambda=235 \mathrm{~nm})$

UV-A $(15 \mathrm{~W}, \lambda=315-400 \mathrm{~nm})$

$\mathrm{TiO}_{2}$ (Degussa P25); $\left[\mathrm{TiO}_{2}\right]=1 \mathrm{~g} \mathrm{~L}^{-1}$

$\mathrm{UV}(8 \mathrm{~W}, \lambda=253.7 \mathrm{~nm}) ; \mathrm{MF} / \mathrm{UF}$

Pre-treatment: flocculation ( $\mathrm{AlCl}_{3}$

$\left.12 \mathrm{mg} \mathrm{L}^{-1}\right)$ and PAC $\left(0.05 \mathrm{~g} \mathrm{~L}^{-1}\right)$

$\mathrm{TiO}_{2}$ (Degussa P25); $\left[\mathrm{TiO}_{2}\right]=0$

$-1.5 \mathrm{~g} \mathrm{~L}^{-1}$; UV $(\lambda=352 \mathrm{~nm}) ; \mathrm{MF}$

$\mathrm{DOC}_{\text {removal }}(\%) / \mathrm{TiO}_{2}=40-62 ; \mathrm{TiO}_{2}+\mathrm{MF}=70-75$ 
too large to reject low MW trace organics, the lower membrane pore sizes used in nanofiltration (NF) and reverse osmosis (RO), have been shown to effectively reject significant amounts of low MW compounds present in $\mathrm{dE}_{\mathrm{f}} \mathrm{OM}$ (Jarusutthirak et al., 2002; Gur-Reznik et al., 2008).

Removal of $\mathrm{dE}_{\mathrm{f}} \mathrm{OM}$ during membrane processes can occur through multiple mechanisms. First, removal can be governed by adsorption when the organic matter is mainly hydrophobic or has strong hydrogen-bonding characteristics, thus readily adsorb to membranes. In many cases though, removal can occur through steric effects for uncharged solutes or combined steric and electrostatic effects for charged solutes (Bellona et al., 2004). These mechanisms are dependent on the aqueous matrix properties ( $\mathrm{pH}$, salinity, ionic strength), the membrane characteristics (material, surface morphology, pore size, MWCO), and the physicochemical characteristics of $\mathrm{dE}_{\mathrm{f}} \mathrm{OM}$ (e.g., MWD, hydrophobicity/hydrophilicity, acidic charge groups) (Shon et al., 2006b; Le-Minh et al., 2010). Removal of $\mathrm{dE}_{\mathrm{f}} \mathrm{OM}$ by membrane technology is challenging since $\mathrm{dE}_{\mathrm{f}} \mathrm{OM}$ represents a broad range of structurally complex compounds with a wide size distribution and heterogeneous functional chemistry that changes over time.

As shown in Table 1, $\mathrm{dE}_{\mathrm{f}} \mathrm{OM}$ (in terms of $\mathrm{DOC}$ ) was removed up to $40-70 \%$ using UF, while NF and RO led to more than $90 \%$ DOC removal. The removal efficiencies of $\mathrm{dE}_{\mathrm{f}} \mathrm{OM}$ as determined by the $\mathrm{UV}_{254}$ absorbance, were higher than those obtained by the DOC determinations. This is attributed mainly to the removal of the aromatic/hydrophobic compounds which can be preferentially removed by negatively-charged membranes (Lee et al., 2005). Due to the large pore size of MF membranes, their efficiency in removing dissolved organics from wastewater is not prominent (Drewes et al., 2003). For this reason, MF is usually used as a pre-treatment for NF and RO processes to remove suspended particles, while is also widely employed in MBR systems. Only a small proportion of the influent DOC concentration was removed by an UF membrane (Henderson et al., 2011), whereas UF was found to be efficient in removing biopolymers present in $\mathrm{dE}_{\mathrm{f}} \mathrm{OM}$, which mainly comprised proteins, polysaccharides and colloidal organics. In recent years, special emphasis on the evaluation of integrated membrane systems such as UF followed by NF or RO has increased. UF pre-treatment is effective at decreasing NF or RO membrane fouling by reducing turbidity and suspended solids, thus achieving an overall enhanced performance. According to Kim et al. (2002), the integration of UF and RO processes can lead to high removal efficiencies of $\mathrm{dE}_{\mathrm{f}} \mathrm{OM}\left(\mathrm{DOC}_{\mathrm{removal}}=75-90 \%\right)$.

The inevitable fouling process imposes a major challenge for efficient application of the membrane technology. In particular, colloidal material present in $\mathrm{E}_{\mathrm{f}} \mathrm{OM}$ may cause fouling by forming a cake or gel layer on the membrane surface, while dissolved material may cause fouling by precipitating at the membrane surface or adsorbing within the membrane pore space. The membrane fouling can be induced by the interactions of $\mathrm{dE}_{\mathrm{f}} \mathrm{OM}$ with the membrane, as well as the interactions among the organics present in it. These interactions were found to be a function of the organic type (hydrophilic or hydrophobic), intrinsic molecular size and structure, synergistic effects (individual or combined fouling), solution chemistry (ionic strength and calcium content), and membrane characteristics. Additionally, Ivnitsky et al. (2005) reported that $\mathrm{dE}_{\mathrm{f}} \mathrm{OM}$ can serve as a source of nutrients and substrates for the growth of a biofouling layer. Biofouling involves adhesion and growth of microorganisms on the membrane surface, but very little is understood about the fundamental nature of their growth processes.

Membrane fouling that arises from various $\mathrm{dE}_{\mathrm{f}} \mathrm{OM}$ fractions is difficult to predict and control; in fact, there is still a lack of agreement on the role of each $\mathrm{dE}_{\mathrm{f}} \mathrm{OM}$ fraction towards the rate and extent of membrane fouling and this field has been confronted with some confusion. Some studies on the identification of the organic compounds responsible for membrane fouling have reported that the fouling during wastewater treatment is primarily caused by dissolved hydrophobic organic matter, while others reported that hydrophilic materials were the major foulants (Shon et al., 2003; Filloux et al., 2012a,b). SMPs were also found to enhance membrane fouling phenomena (Shon et al., 2004; LeClech et al., 2006; Rosenberger et al., 2006; Jarusutthirak and Amy, 2007; Liang et al., 2007).

Many researchers suggested that the low aromatic hydrophilic neutral and protein macromolecules compounds, which predominantly consist of polysaccharides-like substances (chitin, carbohydrates, and cellulose) and fatty acids present in $\mathrm{dE}_{\mathrm{f}} \mathrm{OM}$, are the most important cause for irreversible membrane fouling (Jarusutthirak et al., 2002; Liang et al., 2007; Henderson et al., 2011; Filloux et al., 2012a,b). These findings were well supported by a study carried out by Jarusutthirak et al. (2002), revealing that proteins, polysaccharides, and aminosugars were the main constituents of $d_{\mathrm{f}} \mathrm{OM}$ which were responsible for the membrane fouling (UF and NF), while the hydrophobic fraction (i.e., humic substances) induced fouling to a lesser extent. Liang et al. (2007) also reported that hydrophilic neutrals (e.g., carbohydrates) were most likely the main foulants of an MBR system. An interesting observation was made by Filloux et al. (2012a) who studied the fouling of UF and MF membranes occurred by secondary treated wastewater effluents collected from either MBR or from CAS treatment plants. It was shown that the unified membrane fouling index of these effluents was different even though they were originated from the same feed source, pointing out the strong influence of the biological step (i.e., $\mathrm{MBR}$ versus $\mathrm{CAS}$ ) in the $\mathrm{dE}_{\mathrm{f}} \mathrm{OM}$ composition. The effluents derived from MBR exhibited higher fouling index (1.5-1.7 times higher) due to their higher SMPs content compared to CAS effluents. Also, the protein-like and low MW compounds present in $\mathrm{dE}_{\mathrm{f}} \mathrm{OM}$ were correlated to a high fouling potential. Meng et al. (2011) and Yang et al. (2011) identified the contribution of protein-like compounds to membrane fouling. Henderson et al. (2011) observed that proteinenriched biopolymers (38-60\% of total foulant layer in terms of DOC) were responsible for the UF membrane fouling, while the fouling resistance was highly correlated with the organic components of the wastewater, measured as total DOC concentration.

In contrast to the aforementioned, other studies have also reported the hydrophobic fractions of $\mathrm{dE}_{\mathrm{f}} \mathrm{OM}$ as the major foulants associated with adsorptive fouling or hydrophobic interactions. This lack of consistency can be attributed to the 
complex and diverse character of $\mathrm{dE}_{\mathrm{f}} \mathrm{OM}$. Shon et al. (2003) studied the fouling of an NF membrane using biologically treated wastewater effluents and concluded that the hydrophobic fraction (i.e., high MW humic compounds) contributed to greater fouling rate of the membrane than that of hydrophilic. Similarly, the hydrophobic fraction (humic substances) of $\mathrm{dE}_{\mathrm{f}} \mathrm{OM}$ was shown to be the main cause of an UF membrane fouling (Shon et al., 2006c). Pramanik et al. (2015) recently reported that MF membrane fouling was caused by the high MW compounds, such as biopolymers and humic substances present in biologically treated secondary effluents.

The extent of membrane fouling and thus the efficiency of membrane filtration in removing $\mathrm{dE}_{\mathrm{f}} \mathrm{OM}$, are highly dependent on the type and extent of any pre-treatment used prior to membrane application (e.g., coagulation/flocculation, activated carbon adsorption). Coagulation can effectively reduce the degree of membrane fouling mainly due to the aggregation of fine particles, leading to the increase of cake permeability or preventing the pore blockage. In addition, Abdessemed and Nezzal (2002) reported that coagulation can reduce fouling by conditioning of the cake by incorporation of fine particles into highly-porous flocs. The most widely used coagulant is ferric chloride but recently the use of polyaluminum chloride ( $\mathrm{PACl}$ ) has become more common. Flocculation with $\mathrm{FeCl}_{3}$ was shown to be effective in removing both low and high MW compounds resulting in lower flux decline of an UF membrane (Shon et al., 2005, 2006b). Activated carbon adsorption has also been considered as a promising means for reducing membrane fouling by removing significant amount of $\mathrm{dE}_{\mathrm{f}} \mathrm{OM}$ (Filloux et al., 2012b). Activated carbon adsorption is further discussed in the subsequent section. Here it is noted that membrane fouling induced by biological growth may be prevented/reduced in the case that wastewater is disinfected with chloramines prior to membrane application, resulting in the formation of $\mathrm{N}$-nitrosamines (e.g., NDMA), which have been shown to pass through NF and RO membranes (Steinle-Darling et al., 2007; Fujioka et al., 2013). However, this practice will lead to elevated concentrations of NDMA with subsequent biological effects upon the discharge of the disinfected wastewater effluents.

In general, membrane technology can be successfully utilized for the $\mathrm{dE}_{\mathrm{f}} \mathrm{OM}$ removal. Nonetheless, an understanding of the contribution of $\mathrm{dE}_{\mathrm{f}} \mathrm{OM}$ components in membrane fouling, which constitutes the major limitation of this treatment system, is needed to provide a basis for appropriate selection and operation of membrane technology for wastewater treatment. A reduction in the rate of fouling may be possible if the $\mathrm{dE}_{\mathrm{f}} \mathrm{OM}$ substances responsible for the fouling are removed through an efficient pre-treatment process.

\subsection{Activated carbon adsorption}

Adsorption is a well-established process for the removal of $\mathrm{dE}_{\mathrm{f}} \mathrm{OM}$ from wastewater due to its strong affinity to hydrophobic organic compounds even at low concentrations (Shon et al., 2006a; Gur-Reznik et al., 2008). Adsorption using activated carbon (AC), either in granular (GAC) or powdered (PAC) form, has been widely used alone or in combination with other treatment processes (i.e., coagulation/flocculation, membrane filtration) (Gur-Reznik et al., 2008; Filloux et al., 2012b). In principle, non-specific dispersive interactions (e.g., van der Waals, dipole-dipole interactions, covalent bonding, etc.) are the dominant mechanisms for the removal of organic compounds in AC adsorption systems (Aksu and Tunç, 2005). The performance of the AC treatment system in removing organic compounds depends on the properties of the adsorbent (e.g., specific surface area, porosity, surface polarity, physical shape of the material, etc.), the characteristics of the adsorbate (e.g., molecular structure, charge, hydrophobicity, etc.), and the aqueous matrix characteristics (e.g., $\mathrm{pH}$, temperature, the presence of other species in the solution, etc.) (Aksu and Tunç, 2005). McCreary and Snoeyink (1980) reported that the solution $\mathrm{pH}$ and phosphate concentration had a marked effect on the adsorption of humic compounds, which improved with decreasing $\mathrm{pH}$ and increasing phosphate concentration. Research on the effect of $\mathrm{pH}$ and ionic strength on the organic matter adsorption, showed that in the absence of strong electrostatic effects, adsorption occurs via a pore filling mechanism in which the available pore volume is filled (Newcombe, 1999).

Previous studies have shown that treatment utilizing AC can remove significant quantities of $\mathrm{dE}_{\mathrm{f}} \mathrm{OM}$ (Abdessemed and Nezzal, 2002; Shon et al., 2004; Gur-Reznik et al., 2008; Filloux et al., 2012b). Gur-Reznik et al. (2008) investigated the adsorption of $\mathrm{dE}_{\mathrm{f}} \mathrm{OM}$ on $\mathrm{GAC}$ as a pre-treatment to $\mathrm{RO}$ of wastewater effluents generated in an MBR. GAC adsorption resulted in $80-90 \% \mathrm{dE}_{\mathrm{f}} \mathrm{OM}$ removal which stabilized the $\mathrm{RO}$ membrane permeability and increased permeate quality. $\mathrm{dE}_{\mathrm{f}} \mathrm{OM}$ removed by GAC treatment was mainly composed of hydrophobic and biodegradable components. In the case of $\mathrm{PAC}$, low or medium $\mathrm{MW} \mathrm{dE}_{\mathrm{f}} \mathrm{OM}$ and organic molecules with low SUVA were removed by $65-70 \%$ (Shon et al., 2004; Filloux et al., 2012b).

Several studies investigated the combined use of coagulation/flocculation to remove high MW compounds and adsorption with PAC to maximize the overall removal of $\mathrm{dE}_{\mathrm{f}} \mathrm{OM}$. Shon et al. (2004) removed significant amounts of hydrophobic (82.9\%) and hydrophilic (53\%) fractions of $\mathrm{dE}_{\mathrm{f}} \mathrm{OM}$ by incorporating flocculation $\left(\mathrm{FeCl}_{3}\right)$ and PAC adsorption. Both low and high MW organic compounds were also reduced (more than $88.2 \%$ of TOC removal). Abdessemed and Nezzal (2002) reported that the combined system $\mathrm{FeCl}_{3} / \mathrm{PAC}$ had a beneficial effect on the removal of $\mathrm{dE}_{\mathrm{f}} \mathrm{OM}\left(\mathrm{COD}_{\text {removal }}=87.9 \%\right)$. AC adsorption has also been considered as a means for reducing membrane fouling, either alone or in combination with other pre-treatment procedures. Kim et al. (2002) tested GAC adsorption as a pre-treatment for the desalination of secondary effluent, in combination with either dual media filtration (sand and anthracite) or dual media filtration and chemical flocculation. TOC removal reached high levels (i.e., 75-90\%) and the fouling of the membrane was negligible due to the presence of GAC. Shon et al. (2006b) examined the effect of flocculation followed by PAC adsorption prior to the application of an UF system for the treatment of a secondary effluent. Their results showed that the aforementioned integration led to the reduction of fouling. Meier and Melin (2005) employed a hybrid process combining PAC with NF for secondary effluent reclamation and their findings showed that 
the pre-treatment contributed to a significant reduction of membrane fouling. The fouling was caused by small neutral and amphiphilic substances present in the $\mathrm{dE}_{\mathrm{f}} \mathrm{OM}$ of the effluent.

In general, introduction of AC process as a pre-treatment step to a membrane system can remove the majority of the low MW organic compounds which cannot be removed by a membrane system alone. Furthermore, it minimizes the membrane fouling that would have occurred in the presence of low MW organics in the water, increasing thus the overall process efficiency. However, it is important to note that the regeneration and reuse of $\mathrm{AC}$ after treatment constitute an important limitation of its application, especially in full-scale wastewater treatment facilities.

AC can also be used as a medium to support biological activity (i.e., biological activated carbon [BAC]), where two mechanisms can take place, i.e., adsorption of $\mathrm{dE}_{\mathrm{f}} \mathrm{OM}$ and degradation of the organic matter adsorbed onto the AC surface by the microorganisms (Shon et al., 2006a; Stalter et al., 2010; Reungoat et al., 2012). Previous investigations clearly indicated the efficiency of BAC combined with enhanced coagulation in removing organic compounds present in secondary wastewater effluents (Aryal et al., 2011). DOC was removed by $83 \%$ by BAC, while the integrated process resulted in higher DOC removal due to the fact that the BAC-treated effluent contained SMPs and humic substances, which in turn were removed by the coagulant. A comparative study of BAC and GAC was recently performed by Pramanik et al. (2015) with the aim to minimize fouling of MF used for wastewater treatment. GAC treatment led to substantial removal of DOC (42-65\%), nevertheless membrane flux was not improved compared to BAC treatment. This behaviour may be attributed to the preferential removal of low and medium MW compounds by GAC rather than high MW organics, such as biopolymers which were responsible for the flux decline. In the case of BAC, the microorganisms contributed to the removal of the biopolymers and the humic compounds adsorbed onto the AC, resulting thus in reduced accumulation of organics in the membrane. Kalkan et al. (2011) demonstrated that BAC can efficiently remove both nitrogen (51.5-54\%) and organic carbon (64.5-81\%) from secondary wastewater.

BAC following ozonation was also found to be efficient in removing SMPs and/or other nitrogenous organic matter (expressed as DON) (Chu et al., 2014). The synergistic effect of ozonation and BAC can be assumed considering the fact that ozone transforms high MW compounds into smaller ones (Santos et al., 2013), enhancing thus the biodegradability of the organic matter, which is then more efficiently removed by a subsequent BAC process ( $\mathrm{Xu}$ et al., 2007; Chu et al., 2012). Nguyen and Roddick (2010) investigated the contribution of ozonation followed by BAC with regard to UF membrane performance in treating activated sludge effluents. Their results revealed that ozonation led to the oxidation of $\mathrm{dE}_{\mathrm{f}} \mathrm{OM}$ to lower MW compounds, which were favourable for alleviating UF membrane flux decline, while BAC further improved the UF flux by removing the TSS of the ozonated effluents. BAC was also proposed as an effective post-treatment step to ozonation (Stalter et al., 2010), since it minimizes the toxic effects associated with the oxidation products originated during ozonation.

\subsection{Anion-exchange resins}

Several studies highlighted the strong potential of anionexchange resins (AERs) to remove negatively charged organic compounds present in various aqueous matrices, as well as non-ionic molecules (Bolto et al., 2002a,b; Fearing et al., 2004; Tan and Kilduff, 2007; Humbert et al., 2008). In principle, two mechanisms are possible for the removal of organic matter by AERs (Fu and Symons, 1990): (i) ion exchange, involving counterion displacement from the resin phase and electrostatic interaction between ionic functional groups, and (ii) physical adsorption, involving van der Waals interactions between non-ionic (hydrophobic) moieties present on organic molecules and the resin polymer backbone.

The efficiency of the organic matter removal by AERs depends on the inner characteristics of the resins (strong or weak base), the aqueous matrix characteristics $(\mathrm{pH}$, ionic strength, etc.), and the organic matter composition and concentration (Humbert et al., 2008). AERs have recently received a significant interest in the scientific literature due to the development of a new AER, namely magnetic ion-exchange resin $\left(\right.$ MIEX $^{\circledR}$ ) (Fearing et al., 2004; Johnson and Singer, 2004; Allpike et al., 2005; Humbert et al., 2008). The MIEX ${ }^{\circledR}$ resin (Orica Watercare Ltd., Australia) was originally developed for the removal of DOC from drinking water. A major feature of this resin is the high content of a magnetic iron oxide compound integrated into its structure. Because of their magnetic properties, the resin beads can be recovered after they are allowed to separate from the suspending solution by gravitational settling at relatively high overflow rates, in excess of $10 \mathrm{~m} \mathrm{~h}^{-1}$ (Singer and Bilyk, 2002; Cornelissen et al., 2009). The MIEX $^{\circledR}$ resin can be easily regenerated and even after several regenerations it yields significant organic matter removal (Matilainen et al., 2010).

The MIEX $^{\circledR}$ process was found efficient in removing DOC (higher than $70 \%$ ) from wastewater effluents. $\mathrm{dE}_{\mathrm{f}} \mathrm{OM}$ fractions of both low and high MW are known to be removed by MIEX ${ }^{\mathbb{B}}$ (Filloux et al., 2012b; Nguyen et al., 2011; Wang et al., 2014). The MIEX $^{\circledR}$ resin removed the majority of hydrophilic compounds and significant amounts of hydrophobic compounds within a short contact time $(20 \mathrm{~min}$ ) (Zhang et al., 2006). It also removed small MW (500-1000 Da) organic compounds. The combination of the magnetic resin with PAC was reported to increase $\mathrm{dE}_{\mathrm{f}} \mathrm{OM}$ removal (up to $80 \%$ expressed as TOC removal). The combination of $\mathrm{MIEX}^{\circledR}$ and flocculation followed by submerged membrane system led to a very high $\mathrm{UV}_{254}$ absorbance removal of more than 90-95\% (Zhang et al., 2007). MIEX ${ }^{\circledR}$ removed the hydrophilic fraction of $d_{f_{f}} \mathrm{OM}$ and mainly the small MW (345-688 Da) organic compounds. Wang et al. (2014) observed the preferential removal of humic acid-like and fulvic acid-like fractions, as well as SMPs, from wastewater effluents. $\mathrm{dE}_{\mathrm{f}} \mathrm{OM}$ was significantly removed by MIEX ${ }^{\circledR}$ with both DOC and $\mathrm{UV}_{254}$ absorbance removal to be nearly $80 \%$. The preferential removal of aromatic organic compounds (MW above $10 \mathrm{kDa}$ ) present in $\mathrm{dE}_{\mathrm{f}} \mathrm{OM}$ by $\mathrm{MIEX}^{\mathbb{R}}$ was reported by Zhang et al. (2012), indicating the high efficiency of the resin in decreasing SUVA. Besides the high $\mathrm{dE}_{\mathrm{f}} \mathrm{OM}$ removal achieved by $\mathrm{MIEX}^{\circledR}$, it should be stressed out that its application requires small load of influent and high 
operating pressure (Wang et al., 2014), limiting thus its utilization in WWTPs.

\subsection{Advanced chemical oxidation processes}

Advanced chemical oxidation processes (AOPs) have been studied over the past 30 years and the scientific literature surrounding their application in the water and wastewater treatment field is quite extensive (Klavarioti et al., 2009). The most common AOPs that have been used and evaluated in the wastewater treatment field with respect to the $\mathrm{dE}_{\mathrm{f}} \mathrm{OM}$ removal are: UV-driven photolysis combined with hydrogen peroxide $\left(\mathrm{H}_{2} \mathrm{O}_{2}\right)$ (Audenaert et al., 2013; González et al., 2013; Souza et al., 2014; Umar et al., 2015); ozonation and combination of $\mathrm{H}_{2} \mathrm{O}_{2}$ with ozone $\left(\mathrm{O}_{3}\right)$ (Gong et al., 2008; Rosario-Ortiz et al., 2008b; Rosal et al., 2009; Linlin et al., 2011; Filloux et al., 2012b; Gonzáles et al., 2012; Sharif et al., 2012; Audenaert et al., 2013); homogeneous photocatalysis with Fenton reagent (Li et al., 2012, 2013; Michael et al., 2012b) and heterogeneous photocatalysis with semiconductor materials such as $\mathrm{TiO}_{2}$ (Shon et al., 2005; Erdei et al., 2008; Ho et al., 2010). The complex and variable chemical composition and properties of $\mathrm{dE}_{\mathrm{f}} \mathrm{OM}$ have a direct impact on the oxidation processes performance and hence, increased insight into the mechanisms occurring is essential for their optimization and proper control. It should be highlighted that there are limited studies on advanced chemical oxidation of $\mathrm{dE}_{\mathrm{f}} \mathrm{OM}$ since most of the experiments have been carried out either using surface water (i.e., dissolved NOM) or using various microcontaminants spiked in wastewater effluents at high concentration level $\left(\mathrm{mg} \mathrm{L}^{-1}\right)$. Matilainen and Sillanpää (2010) provided a comprehensive review on the various AOPs employed with regard to the removal of dissolved NOM from drinking water.

The main reactions of hydroxyl radicals ( $\left.\mathrm{HO}^{\circ}\right)$, the latter being formed during the application of AOPs, with organic matter proceed via three principal mechanisms: (i) hydrogen abstraction from aliphatic carbon atoms yielding carboncentred radicals, (ii) electrophilic addition to double bonds or aromatic rings, and (iii) electron transfer reactions, where HO accepts an electron from an organic substituent. The generated organic radicals continue reacting, prolonging a series of chain reactions (Legrini et al., 1993; Malato et al., 2009). In a recent study, wastewater effluent samples were analyzed to identify the main factors (i.e., bulk properties of $\mathrm{dE}_{\mathrm{f}} \mathrm{OM}$, matrix qualitative characteristics, and operating parameters of different wastewater treatment processes) affecting the reactivity of $\mathrm{dE}_{\mathrm{f}} \mathrm{OM}$ towards $\mathrm{HO}$ (Keen et al., 2014). The second-order reaction rate constants between $\mathrm{dE}_{\mathrm{f}} \mathrm{OM}$ and $\mathrm{HO}^{\circ}\left(k_{\mathrm{dE}_{\mathrm{f}} \mathrm{OM}-\mathrm{HO}}\right)$ were determined during the bench-scale $\mathrm{UV} / \mathrm{H}_{2} \mathrm{O}_{2}$ experiments with methylene blue as a probe and during electron pulse radiolysis $\left(k_{\mathrm{dE}_{f} \mathrm{OM}-\mathrm{HO}}=1.6-3.3 \times 10^{8} \mathrm{M}^{-1} \mathrm{~s}^{-1}\right)$. Four variables, i.e., COD, TOC, retention onto $\mathrm{NH}_{2}$ extraction medium (a measure of the prevalence of charged functional groups (Rosario-Ortiz et al., 2008a)), and fluorescence index (FI) (a measure of the degree of bond conjugation of $\mathrm{dE}_{\mathrm{f}} \mathrm{OM}$ ) were identified as the dominant parameters affecting $\mathrm{dE}_{\mathrm{f}} \mathrm{OM}$ reactivity with $\mathrm{HO}$. Also, it was found that different types of processes (e.g., secondary clarifier, activated sludge, nitrifying/denitrifying trickling filter, and final effluent prior disinfection) did not cause statistically significant changes in $k_{d E_{f} \mathrm{OM}-\mathrm{HO}}$, while in some cases, an increase in the rate constant at high SRTs was observed. The SRT can affect the reaction of $\mathrm{dE}_{\mathrm{f}} \mathrm{OM}$ with $\mathrm{HO}^{*}$ via the formation of SMPs, whose properties will dictate the scavenging degree. Similar studies on the elucidation of the relationship between $k_{d E_{f} \mathrm{OM}-\mathrm{HO}}$ and the physicochemical properties of $\mathrm{dE}_{\mathrm{f}} \mathrm{OM}$ derived from different wastewater treatment facilities, were performed by Rosario-Ortiz et al. (2008a) $\quad\left(k_{\mathrm{dE}_{\mathrm{f}} \mathrm{OM}-\mathrm{HO}}=0.27-1.21 \times 10^{9} \mathrm{M}^{-1} \mathrm{~s}^{-1}\right)$ and Dong et al. $(2010)\left(k_{d_{f} \mathrm{OM}-\mathrm{HO}}=6.32-14.1 \times 10^{8} \mathrm{M}^{-1} \mathrm{~s}^{-1}\right)$. These studies revealed that $k_{d E_{f} \mathrm{OM}-\mathrm{HO}}$ is a function of SUVA, FI, MW, and polydispersity (a measure of the heterogeneity of sizes of molecules in a mixture). The results presented herein indicate that the ability to estimate the reactivity of $\mathrm{dE}_{\mathrm{f}} \mathrm{OM}$ with HO would allow design engineers and modellers to predict the overall 'scavenging' effect through the competitive reactions that lead to the consumption of HO', allowing thus to properly optimize AOPs. This would also enable a better assessment of the concentration and utilization of $\mathrm{HO}^{*}$ during full-scale application of AOPs.

Westerhoff et al. (2007) determined the average $k_{\mathrm{dE}_{\mathrm{f}} \mathrm{OM}-\mathrm{HO}}$ for $\mathrm{HO}^{\cdot}$ reactions with $\mathrm{dE}_{\mathrm{f}} \mathrm{OM}\left(k_{\mathrm{dE}_{\mathrm{f}} \mathrm{OM}-\mathrm{HO}}=1.39-\right.$ $4.53 \times 10^{8} \mathrm{M}^{-1} \mathrm{~s}^{-1}$ ) by performing electron pulse radiolysis and transient adsorption spectroscopy experiments on fractionated $\mathrm{dE}_{\mathrm{f}} \mathrm{OM}$ (hydrophobic/transphilic acids and neutrals) from a WWTP. Their results revealed that transphilic and neutral fractions of $\mathrm{dE}_{\mathrm{f}} \mathrm{OM}$ have the highest $k_{\mathrm{dE}_{f} \mathrm{OM}-\mathrm{HO}} \cdot$. In addition, $\mathrm{dE}_{\mathrm{f}} \mathrm{OM}$ oxidation products exhibit lower reaction rate constants with $\mathrm{HO}^{\circ}$ than the initial compounds present in $\mathrm{dE}_{\mathrm{f}} \mathrm{OM}$ and may vary depending on the origin of the $\mathrm{dE}_{\mathrm{f}} \mathrm{OM}$. Future work is needed to elucidate the importance of these oxidation products on $\mathrm{HO}^{\circ}$ reactions, in order to understand whether the reaction rate constant would be dependent on the oxidation state of $\mathrm{dE}_{\mathrm{f}} \mathrm{OM}$ (i.e., structural changes that occur to $\mathrm{dE}_{\mathrm{f}} \mathrm{OM}$ ) throughout the application of AOPs. It was also shown that upon radiolysis and oxidation by $\mathrm{HO}^{\circ}$, electrons are shuttled throughout the organic compounds present in $\mathrm{dE}_{\mathrm{f}} \mathrm{OM}$ by quinone-like moieties, hindering thus the effective attack by HO: This behaviour can also be supported by the fact that $\mathrm{dE}_{\mathrm{f}} \mathrm{OM}$ transients are stable for milliseconds. It is important to highlight that in the case of photochemical AOPs, the role of $\mathrm{dE}_{\mathrm{f}} \mathrm{OM}$ still remains unclear and controversial because both photosensitizing and inhibitory effects of $\mathrm{dE}_{\mathrm{f}} \mathrm{OM}$ on the formation of reactive oxidative species (ROS) have been observed ( $\mathrm{Ng}$ et al., 2014). Of course, each AOP is described by distinct mechanisms, however, a detailed description of the reaction mechanisms occurring between $\mathrm{HO}^{*}$ with $\mathrm{dE}_{\mathrm{f}} \mathrm{OM}$ reactions is beyond the scope of this review.

As shown in Table 1, $\mathrm{dE}_{\mathrm{f}} \mathrm{OM}$ has been observed to decrease (in terms of DOC, SUVA and/or $\mathrm{UV}_{254}$ removal) during the application of various AOPs. However, the extent of $d_{\mathrm{f}} \mathrm{OM}$ reduction by AOPs is always study-specific depending on the amount/type of organic content and other water quality characteristics, as well as the treatment technology. Complete mineralization of $\mathrm{dE}_{\mathrm{f}} \mathrm{OM}$ (i.e., conversion of the organic load into $\mathrm{CO}_{2}, \mathrm{H}_{2} \mathrm{O}$, and inorganic salts) during AOPs, under conditions of practical significance, has not been observed in any case. This implies a considerable residual organic load 
which may be attributed to the presence of persistent oxidation products less susceptible towards $\mathrm{HO}^{\circ}$ attack (Tercero Espinoza and Frimmel, 2009).

The preferential removal of hydrophobic compounds during AOPs has been reported (Li et al., 2012), while studies have also revealed that although the fraction of $\mathrm{dE}_{\mathrm{f}} \mathrm{OM}$ with highly hydrophobic acids is reduced during oxidation, a relative increase occurs in the hydrophilic charged and/or hydrophilic neutral $\mathrm{dE}_{\mathrm{f}} \mathrm{OM}$ fractions (Audenaert et al., 2013). Also, the shift of the MWD towards lower MW compounds during the application of AOPs has been observed in many cases, e.g., ozonation (Linlin et al., 2011; Filloux et al., 2012b), UV/ $\mathrm{H}_{2} \mathrm{O}_{2}$ (Audenaert et al., 2013), Fenton/photo-Fenton oxidation (Li et al., 2012, 2013) and $\mathrm{TiO}_{2}$ photocatalysis (Shon et al., 2005).

\subsubsection{UV-based applications (UV, $U V / \mathrm{H}_{2} \mathrm{O}_{2}$ )}

Irradiation with either an artificial light source (usually performed with low- or medium-pressure mercury vapour lamps) or natural sunlight is a potential means to remove $\mathrm{dE}_{\mathrm{f}} \mathrm{OM}$. $\mathrm{dE}_{\mathrm{f}} \mathrm{OM}$ photolysis can occur through the direct absorption of the emitted light which leads to the triplet excited-state of $\mathrm{dE}_{\mathrm{f}} \mathrm{OM}\left({ }^{3} \mathrm{dE}_{\mathrm{f}} \mathrm{OM}^{*}\right)$. Strong reactive agents, e.g., singlet oxygen $\left({ }^{1} \mathrm{O}_{2}\right)$, $\mathrm{HO}$, or alkyl peroxyl radicals ('OOR) are generated in situ which can significantly enhance the oxidation potential in the chemical system (Litter, 2005; Fatta-Kassinos et al., 2011c). UV-driven processes combined with $\mathrm{H}_{2} \mathrm{O}_{2}$ (which yield additional $\mathrm{HO}^{\circ}$ from its dissociation) significantly enhance the efficiency of the oxidation process by further reducing the $\mathrm{dE}_{\mathrm{f}} \mathrm{OM}$ (Audenaert et al., 2013; González et al., 2013; Umar et al., 2015). UV-driven processes are commonly used in WWTPs for tertiary treatment, nonetheless the number of the research studies performed to date with regard to their efficiency in removing $d_{\mathrm{f}} \mathrm{OM}$ as a global surrogate parameter is small.

González et al. (2013) studied the fate of different $\mathrm{dE}_{\mathrm{f}} \mathrm{OM}$ fractions (i.e., biopolymers, humic substances, building blocks, low molar mass (LMM) neutrals and acids) present in two secondary treated effluents from a CAS and an MBR system during $\mathrm{UV} / \mathrm{H}_{2} \mathrm{O}_{2}$ oxidation. In the case of CAS, the degradation rate of biopolymers was higher in comparison to the humic substances and the LMM fractions. It was found that the $\mathrm{UV} / \mathrm{H}_{2} \mathrm{O}_{2}$ process produced an effluent with lower biopolymer and LMM compounds (building blocks, neutrals and acids) content, while a significant amount of humic substances still remained after treatment. The final $\mathrm{dE}_{\mathrm{f}} \mathrm{OM}$ consisted of $74.1 \%$ LMM compounds (16\% acids, $27.1 \%$ building blocks and 31\% neutrals), while within the high MW compounds $(25.9 \%)$ humic substances were the predominant fraction (19.6\%). In contrast, HO generated during the oxidation of the MBR effluents preferentially attacked humic substances, which were the most abundant fraction in these effluents. At the end of the treatment, the building blocks contribution stood out within the $\mathrm{dE}_{\mathrm{f}} \mathrm{OM}$ composition: $0.8 \%$ biopolymers, $11.7 \%$ humic substances, $24 \%$ LMM neutrals, $14.9 \%$ LMM acids and $48.6 \%$ building blocks. SUVA of both CAS and MBR effluents decreased during the first $30 \mathrm{~min}$ of oxidation (approx. 60-63\%), resulting in poorly aromatic effluents, and then remained nearly constant until the end of the oxidation process. In a recent study performed by Audenaert et al. (2013), $\mathrm{UV} / \mathrm{H}_{2} \mathrm{O}_{2}$ treatment drastically changed the polarity of $\mathrm{dE}_{\mathrm{f}} \mathrm{OM}$. At the end of the reactions, most of the $\mathrm{dE}_{\mathrm{f}} \mathrm{OM}$ was hydrophilic in nature and the hydrophobic fraction was almost completely removed. Also, the oxidation process led to a progressive reduction of $\mathrm{UV}_{254}$ absorbance over the entire apparent MW range. In general, UV-driven photolysis has been observed to induce significant changes in organic matter structural characteristics leading to a reduction in high MW UV-absorbing species (Frimmel, 1998).

During UV-driven photolysis, the structural characteristics of $\mathrm{dE}_{\mathrm{f}} \mathrm{OM}$ (i.e., aromaticity, carbon bonding and functional groups) are directly related to the reactivity with HO: Other important parameters include the molar extinction coefficient and the MW of the compounds. An organic compound with a higher extinction coefficient is more susceptible to photolytic decomposition. Also, the inorganic chemical species present in the aqueous matrix and UV fluence are also considered important factors governing the removal efficiency of $d_{\mathrm{f}} \mathrm{OM}$ during photolysis. Certain species that can be classified as HO' scavengers can adversely affect the $\mathrm{dE}_{\mathrm{f}} \mathrm{OM}$ reduction in wastewater. High concentration of inorganic substances such as carbonates/bicarbonates and chlorides can render $\mathrm{dE}_{\mathrm{f}} \mathrm{OM}$ removal quite slow and inefficient (Michael et al., 2012a; Umar et al., 2015).

According to the authors' knowledge, no information is currently available in the scientific literature regarding the effect of UV fluence on the $\mathrm{dE}_{\mathrm{f}} \mathrm{OM}$ removal. Some studies reported the effect of UV fluence in the case of dissolved NOM removal from reservoir water; however the inconsistent literature data does not allow comparison among the various studies conducted. A significant reduction of $\mathrm{UV}_{254}$ absorbance (91\%) was observed with high UV fluence values (up to $1100 \mathrm{~mJ} \mathrm{~cm}^{-2}$ ) but, this was accompanied by an insignificant DOC reduction (Goslan et al., 2006). A similar study showed $95 \%$ and $30 \%$ of $\mathrm{UV}_{254}$ absorbance and DOC reduction,

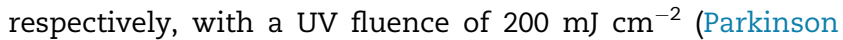
et al., 2003). Chin and Bérubé (2005) reported that the maximum UV fluence used $\left(1600 \mathrm{~mJ} \mathrm{~cm}^{-2}\right)$ did not result in any significant reduction of TOC or $\mathrm{UV}_{254}$ absorbance. Considering the pool of the complex organic compounds and the SMPs present in $\mathrm{dE}_{\mathrm{f}} \mathrm{OM}$ compared to the dissolved NOM, it may be assumed that higher UV doses will be needed for its efficient removal. Noteworthy, however, is that the above statement is merely hypothetical and further research will be needed to back up and confirm the hypothesis.

Several drawbacks are associated with the use of conventional UV lamps, such as instability upon long-term exposure due to overheating, low photonic efficiency resulting in high energy consumption and short lifetime. Within this context, the development of LEDs technology has opened the possibility of employing LEDs as novel UV irradiation source in photolytic applications. LEDs offer significant merits over conventional UV lamps, such as long lifetime, high efficiency in removing potentially pathogenic bacteria from wastewater effluents, high spectral purity, flexible configuration enabling the construction of reactors with variable geometries (i.e., the reactor shape is no longer dependent on the lamp shape) and avoiding the use of hazardous mercury (from conventional UV lamps), and small footprint. Umar et al. (2015) demonstrated the high potential of LEDs-driven process in the presence of 
$\mathrm{H}_{2} \mathrm{O}_{2}$ and $\mathrm{Al}^{3+}$ in removing the $\mathrm{dE}_{\mathrm{f}} \mathrm{OM}$ present in $\mathrm{RO}$ wastewater concentrate. LEDs $/ \mathrm{H}_{2} \mathrm{O}_{2}$ process yielded $27 \%$ of DOC removal, whereas coagulation removed a significant proportion of the $\mathrm{dE}_{\mathrm{f}} \mathrm{OM}$ ( $55 \%$ reduction of humic substances), leading to an enhanced overall organic reduction after the subsequent LEDs $/ \mathrm{H}_{2} \mathrm{O}_{2}$ treatment $\left(\mathrm{DOC}_{\text {removal }}=52 \%\right)$. Also, the LEDs $/ \mathrm{H}_{2} \mathrm{O}_{2}$ treatment generated low MW compounds amenable to biodegradation, resulting in an overall DOC reduction of $67 \%$.

UV or LEDs-based processes may be expensive due to their high energy requirements. The utilization of natural sunlight as an option of reducing UV energy demand is receiving more interest, especially in the context of sustainable full-scale applications. The main disadvantage, however, of utilizing the solar energy is the low efficiency in $\mathrm{dE}_{\mathrm{f}} \mathrm{OM}$ removal compared to UV energy.

\subsubsection{Ozone-based applications $\left(\mathrm{O}_{3}, \mathrm{O}_{3} / \mathrm{UV}, \mathrm{O}_{3} / \mathrm{H}_{2} \mathrm{O}_{2}, \mathrm{O}_{3}\right)$ $\left.\mathrm{H}_{2} \mathrm{O}_{2} / \mathrm{UV}\right)$}

Ozone $\left(\mathrm{O}_{3}\right)$ is a powerful oxidant used extensively in water and wastewater treatment for disinfection purposes, due to its ability to destroy resistant pathogens. $\mathrm{O}_{3}$ may react with organic matter via two distinct mechanisms: (i) $\mathrm{O}_{3}$ decomposes in water to form $\mathrm{HO}^{*}$, thus inducing indirect oxidation, and (ii) $\mathrm{O}_{3}$ can react selectively with certain functional groups, particularly double bonds and aromatic rings of organic molecules, through an electrophilic mechanism (ozonolysis) (Klavarioti et al., 2009; Dantas et al., 2008). Von Gunten (2003) presented a comprehensive review on the use of ozonation with emphasis on oxidation kinetics and reaction mechanisms.

Analysis of $\mathrm{dE}_{\mathrm{f}} \mathrm{OM}$ prior to and after ozonation showed that $\mathrm{O}_{3}$ oxidation does not significantly reduce DOC, however, the aromaticity (represented by SUVA or $\mathrm{UV}_{254}$ ) was significantly decreased (Linlin et al., 2011; Filloux et al., 2012b; Sharif et al., 2012; Audenaert et al., 2013). Gong et al. (2008) observed that during the ozonation of wastewater effluents, $\mathrm{O}_{3}$ was ineffective in removing DOC because it reacted sequentially with aromatic hydrophobic, transphilic and hydrophilic $\mathrm{dE}_{\mathrm{f}} \mathrm{OM}$ fractions. According to Beltran (2004), aromatic compounds are more susceptible to electrophilic substitution reactions with an electrophilic agent, such as $\mathrm{O}_{3}$. Jeong et al. (2014) demonstrated the partial oxidation of $\mathrm{dE}_{\mathrm{f}} \mathrm{OM}$ by $\mathrm{O}_{3}$ along with coagulation to low MW highly charged compounds with low aromaticity, which in turn resulted in the enhancement of the flux of the UF system employed. During ozonation, high MW hydrophobic compounds (humic-, fulvic- and protein-like compounds) present in $\mathrm{dE}_{\mathrm{f}} \mathrm{OM}$ are transformed more readily than low MW compounds, improving thus the biodegradability of the reclaimed water (Linlin et al., 2011). The preferential reduction of higher MW organic matter could be a result of improved reaction rate with HO (Thomson et al., 2004; Rosario-Ortiz et al., 2008b). Higher MW compounds possess a higher number of active reaction sites than lower MW compounds due to their aromatic character. The simultaneous addition of $\mathrm{H}_{2} \mathrm{O}_{2}$ or UV irradiation to the ozone system (Table 1) leads to an increase in process efficiency with respect to the $\mathrm{DOC}$ and $\mathrm{UV}_{254}$ absorbance removal by accelerating the $\mathrm{O}_{3}$ decomposition and promoting $\mathrm{HO}^{*}$ formation (Domenjoud et al., 2011).
Several operational conditions can affect ozone-based treatment processes with respect to the $\mathrm{dE}_{\mathrm{f}} \mathrm{OM}$ removal, including $\mathrm{O}_{3}$ dose, contact time, $\mathrm{pH}, \mathrm{H}_{2} \mathrm{O}_{2}$ concentration, and UV dose (if used). In general, by increasing the $\mathrm{O}_{3}$ dose, DOC removal is increased. Also, $\mathrm{pH}$ has a major role during ozonation. The $\mathrm{O}_{3}$ decomposition is reduced in acidic $\mathrm{pH}$. This leads to an increased efficiency in the case where the main pathway is ozonolysis. However, if the substances do not react with molecular $\mathrm{O}_{3}$ and the primary reaction is with $\mathrm{HO}^{\circ}$, increased $\mathrm{pH}(\mathrm{pH}$ 8-9) leads to enhanced performance (Tizaoui et al., 2011). Noteworthy, however, is that $\mathrm{O}_{3}$ demand depends on reactor configuration and experimental setup (Audenaert et al., 2013). The use of the $\mathrm{O}_{3} / \mathrm{H}_{2} \mathrm{O}_{2} / \mathrm{UV}$ combined system results in a shorter reaction time than the individual processes.

Catalytic ozonation has been found efficient in reducing $\mathrm{dE}_{\mathrm{f}} \mathrm{OM}$ yielding approximately $50-60 \%$ of TOC removal (Alvárez et al., 2009). To date, however, limited research has been conducted on the structural changes of $\mathrm{dE}_{\mathrm{f}} \mathrm{OM}$ resulting from catalytic ozonation. Although the $\mathrm{dE}_{\mathrm{f}} \mathrm{OM}$ reduction was satisfactory in terms of faster organics degradation and enhancement of the ozonation process, there are many engineering operational issues (such as stability/reuse of the catalyst) to be solved in order to use this process in full-scale application.

It is important to highlight the fact that ozonation of bromide-containing wastewater leads to the formation of bromate and brominated DBPs (e.g., bromoform, bromoacetic acids, dibromoacetone, dibromoacetonitrile, etc.) with potential carcinogenic effects (Richardson and Ternes, 2005). According to Wert et al. (2007), at ozone dosages higher than the instantaneous $\mathrm{O}_{3}$ demand, bromate formation can take place. There are limited studies reporting the formation of brominated DBPs during ozonation of wastewater effluents, since the majority of the studies focused on the potential of specific organic fractions extracted from surface water or groundwater to generate brominated DBPs. For example, it was reported that at high ozone doses $\left(\mathrm{O}_{3} / \mathrm{DOC}<2\right)$, depolymerization of dissolved NOM molecules can take place, which can potentially increase the concentrations of precursors that may become halogenated. On the other hand, at higher ozone doses $\left(\mathrm{O}_{3} / \mathrm{DOC}>2\right)$, ozonation oxidizes some precursors to other non-precursor compounds (and in some cases completely), thus effectively reducing the precursor levels available for brominated DBPs formation (Huang et al., 2004). Furthermore, the formation of the potentially carcinogenic NDMA during ozonation of wastewater effluents in a WWTP was reported by Hollender et al. (2009). It is therefore crucial to take into consideration the potential for producing brominated DBPs and NDMA during wastewater ozonation.

\subsubsection{Homogeneous photocatalysis using the Fenton reagent} Extensive research on the application of Fenton and photoFenton processes to treat a wide variety of organic contaminants present in various aqueous matrices (e.g., wastewater effluents, surface water) has been reported (Trovó et al., 2008; Pérez-Moya et al., 2010; Michael et al., 2012a,b). Generally, the process efficiency is strongly influenced by the presence of organic matter that interacts readily with $\mathrm{HO}^{*}$ with reaction rate constants ranging between $10^{8}-10^{10} \mathrm{M}^{-1} \mathrm{~s}^{-1}$ (Rosario- 
Ortiz et al., 2008a; Dong et al., 2010). As a result, $\mathrm{dE}_{\mathrm{f}} \mathrm{OM}$ is expected to be the primary reaction substrate under the most relevant conditions of the Fenton wastewater treatment. On the other hand, $\mathrm{dE}_{\mathrm{f}} \mathrm{OM}$ can induce complexation of dissolved ferric iron $\left(\mathrm{Fe}^{3+}\right)$ leading to the formation of stable and soluble (at natural $\mathrm{pH}$ ) complexes $\left(\mathrm{Fe}^{3+}-\mathrm{dE}_{\mathrm{f}} \mathrm{OM}\right.$ ) which can participate in further reactions (De la Cruz et al., 2012).

The capacity of the Fenton/photo-Fenton systems to remove $\mathrm{dE}_{\mathrm{f}} \mathrm{OM}$ is primarily affected by $\mathrm{H}_{2} \mathrm{O}_{2}$ and $\mathrm{Fe}^{2+}$ concentrations, $\mathrm{pH}$, and reaction time. Optimization of the catalyst and oxidant ratio renders the Fenton processes suitable to treat complex aqueous matrices rich in $\mathrm{dE}_{\mathrm{f}} \mathrm{OM}$. Malato et al. (2009) presented a comprehensive review on the main process parameters and their influence on the Fenton/ photo-Fenton systems efficiency in removing various organic compounds dissolved in water or wastewater. Although previous studies have shown that the optimum operating $\mathrm{pH}$ for Fenton/photo-Fenton processes is near 3 (Park and Yoon, 2007; Moncayo-Lasso et al., 2008), it was reported by Goslan et al. (2006) that $\mathrm{UV}_{254}$ absorbance and DOC reduction of humic acid solution were significant within a $\mathrm{pH}$ range of 3-7. These conditions may be more feasible and cost-effective for full-scale treatment applications, since $\mathrm{pH}$ adjustment would not be necessary.

Reported results for Fenton and photo-Fenton processes have shown the potential of these systems to treat wastewater rich in $\mathrm{dE}_{\mathrm{f}} \mathrm{OM}$ yielding up to $70 \%$ of $\mathrm{DOC}$ removal, while $\mathrm{UV}_{254}$ absorbance was significantly reduced (Michael et al., 2012b; Li et al., 2013; Rodríguez-Chueca et al., 2014). While the effect of $\mathrm{dE}_{\mathrm{f}} \mathrm{OM}$ on the Fenton process performance has not been examined in sufficient detail (most studies are devoted to the removal of specific organic microcontaminants rather than $\mathrm{dE}_{\mathrm{f}} \mathrm{OM}$ ), some alterations of $\mathrm{dE}_{\mathrm{f}} \mathrm{OM}$ structural characteristics during the application of Fenton process were reported. Li et al. (2012) demonstrated that during the Fenton process, preferential removal of high MW compounds in $\mathrm{dE}_{\mathrm{f}} \mathrm{OM}$ was observed. In addition, the relative modifications of absorbance at $254 \mathrm{~nm}$ were strongly correlated with $\mathrm{Fe}^{2+}$ concentration and contact time. According to Li et al. (2013), protein-like compounds and SMPs were the most readily removed species by both Fenton and Fenton-like processes compared to humic- and fulvic-like substances. These results could be linked to a very interesting conclusion. Since the reaction rate between organic molecules with unsaturated bonds and HO tends to be higher compared to that for organic molecules containing predominantly saturated bonds (Westerhoff et al., 1999), it may be assumed that SMPs consist of organic compounds with unsaturated bonds which can react readily with $\mathrm{HO}^{\circ}$ during the Fenton process.

\subsubsection{Heterogeneous photocatalysis $\left(\mathrm{TiO}_{2} / \mathrm{UV}\right)$}

Heterogeneous photocatalytic processes using $\mathrm{TiO}_{2}$ have attracted considerable attention recently due to their applicability to a variety of organic microcontaminants and utilization of solar energy. Organic compounds can be degraded by HO which are formed from the reaction of water molecules with the $h_{\mathrm{V} B}^{+}$on the catalysts' surface (Herrmann et al., 1993; Banerjee et al., 2014). In addition, adsorption of organic compounds onto the catalysts' surface can occur.
The efficiency of heterogeneous photocatalytic systems for organic matter removal depends on a number of parameters, such as the catalyst loading, the addition of oxidant and the solution $\mathrm{pH}$. In general, higher $\mathrm{TiO}_{2}$ concentrations have achieved greater DOC and $\mathrm{UV}_{254}$ absorbance removals. Nevertheless, beyond a certain level, additional $\mathrm{TiO}_{2}$ particles cannot be involved in further reactions due to the increased turbidity and subsequent decrease in UV-light transmission (Ho et al., 2010; Mueses et al., 2013). The $\mathrm{H}_{2} \mathrm{O}_{2}$ addition in the $\mathrm{TiO}_{2}$-photocatalytic system, enhances the degradation rate of the organic compounds by promoting the charge separation (inhibiting $e_{\mathrm{CB}}^{-}-h_{\mathrm{VB}}^{+}$recombination on the semiconductor surface) and the $\mathrm{HO}^{\circ}$ production. Of course, this increase occurs up to a level which corresponds to the optimum $\mathrm{H}_{2} \mathrm{O}_{2}$ concentration.

It is well known that the adsorption of organic compounds on the catalyst surface is strongly dependent on the solution $\mathrm{pH}$. According to the authors' knowledge, the adsorption of $\mathrm{dE}_{\mathrm{f}} \mathrm{OM}$ onto the catalyst particles has not been studied. Some studies reported that the adsorption of humic substances plays a significant role in their photocatalytic degradation under acidic $\mathrm{pH}$ conditions, where the adsorption of carboxylic surface groups onto $\mathrm{TiO}_{2}$ can be reinforced (Tran et al., 2006; Liu et al., 2008). Wiszniowski et al. (2002) used diffuse reflectance FTIR technique to demonstrate that the adsorption occurred via the interaction of carboxylate groups in the humic acid molecules with the $\mathrm{TiO}_{2}$ surface under acidic $\mathrm{pH}$. Moreover, it has been reported that hydrophobic dissolved NOM is preferably adsorbed onto $\mathrm{TiO}_{2}$ surface, and more hydrophilic oxidation products are then desorbed (Huang et al., 2008). Here it is noted that the effect of $\mathrm{pH}$ on the adsorption of various microcontaminants present in $\mathrm{dE}_{\mathrm{f}} \mathrm{OM}$ (e.g., PPCPs) is compound-specific involving complex reactions.

Shon et al. (2005) reported that $\mathrm{TiO}_{2}$ photocatalytic treatment of $\mathrm{dE}_{\mathrm{f}} \mathrm{OM}$ provoked both a positive and negative effect, the latter being eliminated by the simultaneous addition of $\mathrm{PAC}$ or $\mathrm{FeCl}_{3}$ in the oxidation system. In a later study by Shon et al. (2007), the removal of specific fractions of $\mathrm{dE}_{\mathrm{f}} \mathrm{OM}$ (i.e. hydrophophic, hydrophilic, transphilic) during the coupling of $\mathrm{TiO}_{2}$ photocatalysis with $\mathrm{FeCl}_{3}$ flocculation and PAC adsorption was investigated. The preferential removal (approx. 80\%) of hydrophobic and transphilic compounds during UV-C-driven $\mathrm{TiO}_{2}$ photocatalysis has been demonstrated, resulting in residual organic matter comprising compounds of hydrophilic nature. $\mathrm{TiO}_{2}$ photocatalysis removed $70 \%$ of the overall DOC, whereas the addition of $\mathrm{FeCl}_{3}$ and PAC in the photocatalytic system enhanced the removal of $\mathrm{dE}_{\mathrm{f}} \mathrm{OM}$ to $92.1 \%$ and $77.5 \%$, respectively. In the case of the combined $\mathrm{TiO}_{2} / \mathrm{PAC}$ system, the increase in the $\mathrm{dE}_{\mathrm{f}} \mathrm{OM}$ removal may be attributed to the adsorption of the $\mathrm{TiO}_{2}$-photodegraded compounds onto the PAC particles.

In general, there are limited studies on the application of $\mathrm{TiO}_{2}$ photocatalytic process with respect to the monitoring and characterization of $\mathrm{dE}_{\mathrm{f}} \mathrm{OM}$ fractions during the various treatment steps. Most of the research carried out so far has been concentrated on the effect of heterogeneous photocatalysis on the removal of dissolved NOM present in surface water and its structural alterations during treatment. For example, HPSEC was used to fractionate dissolved NOM at 
different stages of the $\mathrm{TiO}_{2}$ photocatalytic process to characterize the shift in the MWD (Liu et al., 2008; Tercero Espinoza and Frimmel, 2009). Conversely, Carp et al. (2004) reported different kinetic models for the $\mathrm{TiO}_{2}$ degradation of dissolved NOM even under similar conditions. This can be attributed to the multi-component composition of dissolved NOM present in various water sources and the analytical techniques used to characterize its structural characteristics and properties (Gaffney et al., 1996). Arana et al. (2002) observed a uniform $\mathrm{TiO}_{2}$ particle size distribution on the PAC surface and that the rate of organic matter removal by the $\mathrm{TiO}_{2}$ together with PAC was six times higher than that with $\mathrm{TiO}_{2}$ alone. Similar combined treatment processes, incorporating $\mathrm{TiO}_{2}$ photocatalytic oxidation with either ozonation or coagulation/ flocculation, produced higher dissolved NOM removal (Uyguner et al., 2007; Mosteo et al., 2009).

Recently, the idea of integrating photocatalysis with low-pressure submerged membranes (e.g., MF) has attracted considerable attention (Huang et al., 2007; Erdei et al., 2008; Ho et al., 2010). In the combined system, filtration aids in the separation of suspended catalysts, while semiconductor particles reduce membrane fouling by degrading organic compounds present in $\mathrm{dE}_{\mathrm{f}} \mathrm{OM}$. Ho et al. (2010) assessed the performance of a $\mathrm{TiO}_{2}$-photocatalytic-membrane hybrid system in removing $\mathrm{dE}_{\mathrm{f}} \mathrm{OM}$. $\mathrm{TiO}_{2}$ photocatalysis led to a significant DOC reduction $\left(\mathrm{DOC}_{\text {removal }}=62 \%\right)$, which in turn enhanced membrane filtration flux resulting in a higher DOC removal (70-75\%). This study revealed the high adsorption potential of humic substances present in $\mathrm{dE}_{\mathrm{f}} \mathrm{OM}$ onto the membrane surface. This observation is supported by the fact that the membrane pore size used in this study (i.e., $0.1 \mu \mathrm{m}$ ) is much higher than the equivalent size of humic substances. In a treatment train comprised $\mathrm{UV} / \mathrm{TiO}_{2}, \mathrm{PAC}, \mathrm{AlCl}_{3}$ and $\mathrm{MF} / \mathrm{UF}$, a high DOC removal of up to $92 \%$ was achieved (Erdei et al., 2008).

From an engineering point of view, $\mathrm{TiO}_{2}$ slurry systems constitute an important obstacle for full-scale applications of $\mathrm{TiO}_{2}$ photocatalysis since they require an additional step for post-separation and reuse of the catalyst. A new approach for solving problems concerning separation of the photocatalyst from the reaction mixture is the application of immobilized photocatalytic membrane reactors. The latter have many advantages with respect to conventional photoreactors, such as: (i) confinement of the photocatalyst in the reaction solution by means of the membrane and (ii) control of a residence time of molecules in the reactor (Mozia, 2010). According to the authors' knowledge, the immobilized membrane reactors received less attention compared to slurry systems for the treatment of $\mathrm{dE}_{\mathrm{f}} \mathrm{OM}$.

\subsubsection{Biological effects of $d E_{f} \mathrm{OM}$ oxidation products}

It is important to highlight the fact that despite the studies performed for the understanding of $\mathrm{dE}_{\mathrm{f}} \mathrm{OM}$ treatment efficacy, current knowledge in relation to potential biological potency of $\mathrm{dE}_{\mathrm{f}} \mathrm{OM}$ after advanced treatment is still insufficient. In particular, the potential effects of the oxidation products formed during the advanced chemical oxidation of $\mathrm{dE}_{\mathrm{f}} \mathrm{OM}$ should not be overlooked. To date, the majority of the studies performed by the various research groups active in the field, focused on the formation and the effects (considering various biological endpoints) of transformation products of specific microcontaminants present in $\mathrm{dE}_{\mathrm{f}} \mathrm{OM}$ (e.g., PPCPs, EDCS, etc.) spiked in pure water solutions upon their advanced oxidation treatment (Fatta-Kassinos et al., 2011c; Rizzo, 2011; Haddad et al., in press). This certainly prevents scientists from reaching comprehensive conclusions in relation to the formation of oxidation products deriving from the $\mathrm{dE}_{\mathrm{f}} \mathrm{OM}$ itself.

There are few studies on the toxic effects of $\mathrm{dE}_{\mathrm{f}} \mathrm{OM}$ oxidation products, tested as whole effluent undergone oxidation. Michael et al. (2012b) evaluated toxicity (D. magna and three plant species [Sorghum saccharatum, Lepidium sativum, Sinapis alba]) at various steps of the homogeneous photocatalytic treatment (solar Fenton) of wastewater at a pilot scale. The seed germination inhibition and D. magna immobilization was found to be attributed to the $\mathrm{dE}_{\mathrm{f}} \mathrm{OM}$ oxidation products formed during the solar Fenton oxidation process rather than the presence of microcontaminants (i.e., antibiotics) (Michael et al., 2012b). The toxic and genotoxic effect of ozone-treated wastewater effluents towards Lytechinus variegatus and zebra mussels (i.e., comet assay) was demonstrated in Stalter et al. (2010) due to the formation of $\mathrm{dE}_{\mathrm{f}} \mathrm{OM}$ oxidation products. The toxicity of ozonated wastewater effluents as a result of the formation of oxidation products was also evidenced in Switzerland, by applying a battery of bioassays (Escher et al., 2009). In vitro and in vivo bioassays conducted to assess the biological effects of UV- and ozone-treated wastewater effluents (Cao et al., 2009), revealed that the $\mathrm{dE}_{\mathrm{f}} \mathrm{OM}$ oxidation products contributed to the biological potency of the whole treated effluent. Therefore, toxicological tests to monitor and control the formation of these harmful oxidation products following AOP-based treatment are mandatory. Of course, the formation of oxidation products upon AOPs application cannot be regarded as a 'cut-off criterion' per se, considering the fact that biodegradation products with unknown biological effects are formed during conventional activated sludge treatment.

\section{Direct and indirect potable wastewater reuse: real case studies}

Certain advanced treatment technologies have experienced popularity over the past few decades in IPR and DPR, possibly due to their simple technological application and economically feasibility. The treatment technologies commonly used in IPR and DPR systems include membrane filtration and separation processes (i.e., MF, UF, NF, RO), as well as chemical oxidation processes, mostly UV- and ozone-based technologies. MF and/or UF are usually used as pre-treatment for NF and RO followed by an advanced oxidation process for further improvement of final effluents' quality. In addition, advanced biological treatment processes, such as BAC, are often employed as pre- or post-treatment in full-scale treatment facilities, in order to enhance the final effluent quality with regard to $\mathrm{dE}_{\mathrm{f}} \mathrm{OM}$ removal and mitigation of recalcitrant and toxic microcontaminants. Examples of IPR and DPR schemes which are currently in operation throughout the world are provided in detail elsewhere (Rodriguez et al., 2009; Gerrity et al., 2013). Therefore, the aim of this section is not to provide an extensive review on this topic, but to discuss the 
application of advanced technologies under 'real scenarios' and conditions along with their efficiency in removing $d E_{f} O M$ and toxicity.

The investigation of three full-scale wastewater reclamation plants in Australia incorporating ozonation followed by BAC filtration and various disinfection processes (i.e., ozone, UV, MF/UV) was reported by Reungoat et al. (2010, 2012). The reclamation plants (Caboolture [8000 $\mathrm{m}^{3}$ day $\left.^{-1}\right]$, Landsborough [2000 $\mathrm{m}^{3}$ day $\left.^{-1}\right]$ and Gerringong [900 $\mathrm{m}^{3}$ day $\left.^{-1}\right]$ ) receive biologically treated effluents. The integration of chemical and biological treatment processes results in 50\% and $90 \%$ removal of DOC and microcontaminants, respectively. It produces also an improved wastewater effluent quality compared to the raw wastewater with low toxicity and estrogenicity (removal of non-specific toxicity and estrogenicity higher than $70 \%$ and $95 \%$, respectively). It is worth noting that the South Caboolture Water Reclamation Plant, which is the largest plant among the aforementioned, provides reclaimed wastewater to be reused in industry, as well as to cover water needs for community consumption.

A similar treatment train is applied in the case of Reno-Stead Water Reclamation Facility in Reno (Nevada, US), where a series of treatment steps follows the conventional biological treatment (i.e., UF/sand filtration, ozone $/ \mathrm{H}_{2} \mathrm{O}_{2}$ and $\mathrm{BAC}$ ), in an effort to establish the required quality criteria for aquifer recharge (Gerrity et al., 2011). The ozone $/ \mathrm{H}_{2} \mathrm{O}_{2}$ process has been found efficient in removing a variety of microcontaminants (>90\%) and effluent aromaticity $\left(\mathrm{U}_{254 \mathrm{removal}}=50 \%\right)$ by preferentially transformed the organic matter associated with SMPs, while BAC was particularly effective for the elimination of persistent oxidation products (>95\%) and 33\% reduction of TOC. Also, ozone/ $\mathrm{H}_{2} \mathrm{O}_{2}$ process has been found to provide a $>6.5$-log viral inactivation and estrogenicity reduction.

The Clark County Water Reclamation District in Las Vegas (Nevada, US) discharges its treated effluents after granular media filtration and disinfection with chlorine or UV, to the Las Vegas Wash, which eventually reaches Lake Mead. According to Gerrity et al. (2013), the reclamation plant will be upgraded with UF and ozone to further reduce the chemical and biological load of the effluents prior to their discharge. Furthermore, UF employed in the F. Wayne Hill Water Resources Center in Gwinnett Country (Georgia, US, $189,270 \mathrm{~m}^{3}$ day $^{-1}$ ), seems to be promising technology in producing an effluent of a high level of purity with the potential to be discharged to the Chattahoochee river and be used for irrigation at local parks and golf courses.

In the US, California is the leading state implementing IPR. $\mathrm{MF}, \mathrm{RO}$ and $\mathrm{UV} / \mathrm{H}_{2} \mathrm{O}_{2}$, are employed prior to groundwater replenishment with the treated effluents (CDPH, 2013). $\mathrm{MF}$ provides substantial removal of $\mathrm{pE}_{\mathrm{f}} \mathrm{OM}$, while $\mathrm{dE}_{\mathrm{f}} \mathrm{OM}$ reduction down to $0.5 \mathrm{mg} \mathrm{L}^{-1}$ (in terms of TOC) is achieved through RO application. The chemical oxidation treatment $\left(\mathrm{UV} / \mathrm{H}_{2} \mathrm{O}_{2}\right)$ following the membrane steps, results in the mitigation of NDMA, as well as in the improvement of the effluent quality with respect to its organic content. Reclaimed wastewater undergoing further treatment with $\mathrm{MF} / \mathrm{RO}$ and $\mathrm{UV} / \mathrm{H}_{2} \mathrm{O}_{2}$ in the City of San Diego, is stored to the San Vicente reservoir and subsequently used for potable water supply.
The combined treatment scheme produces a high quality effluent complying with all the regulated parameters, while it also provides elimination of PPCPs and NDMA (removal > 99\%). A similar treatment (MF/RO, UV) is currently under operation by the PUB-Singapore's National Water Agency, with the only difference being the non-addition of $\mathrm{H}_{2} \mathrm{O}_{2}$. The produced water (known as NEWater) after stabilization (addition of alkaline chemicals) is in compliance with the WHO requirements and can be piped off to its wide range of applications (e.g., reuse in industry, discharge to a drinking water reservoir) (PUB, 2012).

IPR was also employed in the surroundings of Barcelona as a means to overcome the severe drought occurred in 2008 by discharging tertiary treated wastewater effluents (UF/RO, UV + chlorination) in a river (Köck-Schulmeyer et al., 2011).

Windhoek (Namibia) represents a strong example of DPR since 1968, where reclaimed wastewater is directly pumped into the drinking water distribution system (Lahnsteiner and Lempert, 2007). The quality of the final water is validated with extensive monitoring systems against a variety of quality parameters by many organizations (e.g., EPA, EU, WHO, etc) to assure that strict water quality requirements are met. Other examples of DPR are currently implemented in the US (Cloudcroft, New Mexico and Big Spring, Texas), in order to meet the increased and prolonged potable water demands (Tchobanoglous et al., 2011; Gerrity et al., 2013). In Cloudcroft (New Mexico, US), the treatment configurations consist of $\mathrm{MBR}, \mathrm{RO}$ and $\mathrm{UV} / \mathrm{H}_{2} \mathrm{O}_{2}$ and mixing of the treated water with $>51 \%$ of well water. The water is further treated with UF, UV, GAC and chlorination prior to potable distribution. In the case of Big Spring (Texas, US), wastewater passes through MF/RO and then is treated with $\mathrm{UV} / \mathrm{H}_{2} \mathrm{O}_{2}$ followed by flocculation, sedimentation, granular media filtration and chlorination.

Considering that IPR and DPR schemes are implemented in many regions as alternative potable water source, toxicological risk assessments with respect to the remaining $\mathrm{dE}_{\mathrm{f}} \mathrm{OM}$ and its associated products after advanced treatment should not be neglected. Each advanced treatment train poses its own challenges and obstacles, which must be addressed according to the effectiveness and reliability of the treatment processes, regulatory quality requirements and health issues.

\section{Conclusions}

$\mathrm{dE}_{\mathrm{f}} \mathrm{OM}$ remaining following biological wastewater treatment comprises a heterogeneous mixture of refractory organic compounds with diverse structures and functionalities which can reach the aquatic environment via wastewater discharge and reuse practices. Three categories of $\mathrm{dE}_{\mathrm{f}} \mathrm{OM}$ are considered: natural organic matter, soluble microbial products, and trace microcontaminants originating from domestic and/or industrial use. Many analytical methods for the qualitative and quantitative characterization of $\mathrm{dE}_{\mathrm{f}} \mathrm{OM}$ are available; however, currently, a huge gap exists between what analytical methodology is sufficient to provide a complete understanding of the complex structure and the exact composition of $\mathrm{dE}_{\mathrm{f}} \mathrm{OM}$. Furthermore, $\mathrm{dE}_{\mathrm{f}} \mathrm{OM}$ composition is affected by differences in biological wastewater treatment processes and their operational conditions. If not supported by adequate 
$\mathrm{dE}_{\mathrm{f}} \mathrm{OM}$ and operational characterization, any comparative evaluations between various treatment processes cannot be conducted properly.

Despite the fact that wastewater reuse is a strategy that is gaining wider acceptance and is rapidly expanding, there is still a significant number of issues to be tackled with respect to $\mathrm{dE}_{\mathrm{f}} \mathrm{OM}$ originating from treated wastewater. Typical wastewater operational parameters, such as DOC, COD, and conventional microbiological tests, are not adequate alone for the design of wastewater reuse schemes, because the residual $\mathrm{dE}_{\mathrm{f}} \mathrm{OM}$ contains mixtures of organic compounds and their transformation products whose biological potency needs careful assessment and consideration. More in-depth studies are necessary to better understand the potential risk of $d E_{\mathrm{f}} \mathrm{OM}$ towards aquatic organisms and human health. In addition, the accumulation of $\mathrm{dE}_{\mathrm{f}} \mathrm{OM}$ in soil and its uptake potential by plants and crops need to be urgently addressed in the framework of agricultural wastewater reuse. Novel combination of bioassays should be developed and utilised to adequately evaluate long-term effects of $\mathrm{dE}_{\mathrm{f}} \mathrm{OM}$ and subsequently the impacts of repeated wastewater reuse. The knowledge on mechanisms underlying the effects of residual $\mathrm{dE}_{\mathrm{f}} \mathrm{OM}$ is key to predicting its potential risks, and is therefore integral to the development of new wastewater quality guidelines and legislation.

It is inevitable that in the near future, indirect and direct potable reuse will become part of the water management portfolio worldwide. The assessment of the efficiency of various advanced treatment technologies in managing $\mathrm{dE}_{\mathrm{f}} \mathrm{OM}$ in view of the current concerns related to the wastewater reuse and the induction of toxic effects in aquatic organisms indicated that $\mathrm{dE}_{\mathrm{f}} \mathrm{OM}$ removal is highly affected by the source of wastewater, process mechanisms, and the technology operating conditions. In many cases, the lack of data regarding the treatment processes and the experimental configurations, as well as the different qualitative characteristics of $\mathrm{dE}_{\mathrm{f}} \mathrm{OM}$, does not allow comparison among the various studies conducted.

The extent of membrane fouling and the efficiency of membrane filtration in removing $\mathrm{dE}_{\mathrm{f}} \mathrm{OM}$, is highly dependent on the type of the membrane and the pre-treatment processes used prior to membrane application. Due to the large pore size of MF membranes, their efficiency in removing $\mathrm{dE}_{\mathrm{f}} \mathrm{OM}$ from wastewater is not evident, whereas DOC can be removed up to $40-70 \%$ using UF and more than $90 \%$ by employing NF and RO. The membrane technologies generate a residual stream, i.e., the concentrate that is rejected from membrane systems, thereby imposing a dilemma for its proper disposal. AC adsorption treatment (both in powdered and granular form) results in high removal of low MW hydrophobic organic compounds, while $\mathrm{dE}_{\mathrm{f}} \mathrm{OM}$ fractions of low and high MW have been found to be removed by AERs. Of course, the regeneration and reuse of both AC and AERs should not be overlooked.

Among the advanced treatment technologies applied for the $\mathrm{dE}_{\mathrm{f}} \mathrm{OM}$ removal, AOPs present a particularly attractive option as they produce powerful oxidative species capable of degrading a wide range of organic pollutants present in $\mathrm{dE}_{\mathrm{f}} \mathrm{OM}$. The hydrophobic and high MW compounds present in $\mathrm{dE}_{\mathrm{f}} \mathrm{OM}$ have been shown to be more susceptible to oxidation with various AOPs. UV-driven AOPs (i.e., $\mathrm{UV} / \mathrm{H}_{2} \mathrm{O}_{2}$, photoFenton, $\mathrm{TiO}_{2}$ photocatalysis) have demonstrated significant $\mathrm{dE}_{\mathrm{f}} \mathrm{OM}$ removal. Ozone-based processes, on the other hand result in lower $\mathrm{DOC}$ removal; however, aromaticity of $\mathrm{dE}_{\mathrm{f}} \mathrm{OM}$ can be greatly reduced. Of course, the extent of $d_{\mathrm{f}} \mathrm{OM}$ reduction by AOPs is always study-specific, depending on the organic content, other water qualitative characteristics, and the treatment operational parameters. Nonetheless, it must be stated that complete $\mathrm{dE}_{\mathrm{f}} \mathrm{OM}$ removal (in terms of $\mathrm{DOC}$ removal) seldom is attained during the application of AOPs indicating the formation of persistent oxidation products which may exhibit toxic effects and should not be neglected. AOPs as individual processes or integrated with other physical and physicochemical processes (e.g., coagulation, flocculation, and membrane technology) can be optimized further to provide a promising option for wastewater treatment and safe reuse schemes.

According to Muñoz et al. (2009), 'Suitable technologies to reduce the risks from wastewater effluents exist and will have to be chosen on a case-by-case basis'. Obviously, switching from conventional wastewater treatment to advanced treatment can significantly increase costs. In a world where waterenergy-food nexus is becoming increasingly important, energy efficiency should be taken into consideration when selecting an advanced treatment scheme. It is clear that many of the treatment trains described in this review require a significant amount of energy, which increases operational cost. However, urban communities cannot thrive without sufficient and safe water supplies and hence such investments are certainly warranted in many cases. A balance between efficiency, environmental risks, cost and energy should be pursued, especially now that the European Commission has started working on the development of a Wastewater Reuse Directive.

The presence of $\mathrm{dE}_{\mathrm{f}} \mathrm{OM}$ affects the current discharge standards of the treated wastewater effluent and also becomes a primary constraint to safe wastewater reuse. Wastewater reuse guidelines vary from region to region because of particular permit requirements, stakeholder acceptance, financial means, health protection, public acceptance, the level of water stress, and the variety of end uses. However, risk assessment approaches to identify the most critical microbiological and chemical parameters should be developed in a unified approach to underpin the decisions that promote 'Best Reuse Practices'. The 'Best Practice' will depend on the overall reuse strategy, sources of wastewater, and the type of treatment under consideration. In order to promote safe wastewater reuse solutions through a sustainable risk assessment framework, a comprehensive research strategy based on advanced chemical, microbiological, toxicological, and modelling tools is needed to address the critical issues associated with the residual $\mathrm{dE}_{\mathrm{f}} \mathrm{OM}$ and its potential environmental risks.

\section{Acknowledgements}

This work was prepared in the framework of the KOY $\Lambda$ TOYPA/ $\mathrm{BEN} \Sigma / 0412 / 24$ research project 'Closing Gaps of Knowledge with respect to Advanced Chemical Oxidation Processes for 
the Removal of Contaminants of Emerging Concern - GAPS', implemented within the national framework program for research, technological development and innovation 'DESMH 2009-2010'. Nireas-IWRC (NEA YПО $\Delta$ OMH/ 2 TPATH/0308/09) is co-financed by the Republic of Cyprus and the European Regional Development Fund through the Research Promotion Foundation of Cyprus. The authors would like to thank EU for the support provided through COST Action ES1403 'New and emerging challenges and opportunities in wastewater reuse (NEREUS)'.

\section{Appendix A. Supplementary data}

Supplementary data related to this article can be found at http://dx.doi.org/10.1016/j.watres.2015.03.011.

\section{R E F E R E N C E S}

Abbt-Braun, G., Lankes, U., Frimmel, F.H., 2004. Structural characterization of aquatic humic substances - the need for a multiple method approach. Aquat. Sci. 66 (2), 151-170.

Abdessemed, D., Nezzal, G., 2002. Treatment of primary effluent by coagulation-adsorption-ultrafiltration for reuse. Desalination 152 (1), 367-373.

Aksu, Z., Tunç, Ö., 2005. Application of biosorption for penicillin G removal: comparison with activated carbon. Process Biochem. 40 (2), 831-847.

Al-Bastaki, N.M., 2004. Performance of advanced methods for treatment of wastewater: $\mathrm{UV} / \mathrm{TiO}_{2}, \mathrm{RO}$ and UF. Chem. Eng. Process. 43, 935-940.

Allpike, B.P., Heitz, A., Joll, C.A., Kagi, R.I., Abbt-Braun, G., Frimmel, F.H., Brinkmann, T., Her, N., Amy, G., 2005. Size exclusion chromatography to characterize DOC removal in drinking water treatment. Environ. Sci. Technol. 39 (7), 2334-2342.

Alonso, E., Santos, A., Solis, G., Riesco, P., 2001. On the feasibility of urban wastewater tertiary treatment by membranes: a comparative assessment. Desalination 141 (1), 39-51.

Alvárez, P.M., Beltrán, F.J., Masa, F.J., Pocostales, J.P., 2009. A comparison between catalytic ozonation and activated carbon adsorption/ozone-regeneration processes for wastewater treatment. Appl. Catal. B Environ. 92, 393-400.

Aquino, S., Stuckey, D., 2004. Soluble microbial products formation in anaerobic chemostats in the presence of toxic compounds. Water Res. 38 (2), 255-266.

Arana, J., Herrera Melián, J., Doña Rodríguez, J., González Diaz, O. Viera, A., Pérez Peña, J., Marrero Sosa, P., Espino Jiménez, V., 2002. $\mathrm{TiO}_{2}$-photocatalysis as a tertiary treatment of naturally treated wastewater. Catal. Today 76 (2), 279-289.

Aryal, A., Sathasivan, A., Adhikari, R.A., 2011. Evidence that BAC treatment enhances the DOC removal by enhanced coagulation. Desalination 280, 326-331.

Audenaert, W.T., Vandierendonck, D., Van Hulle, S.W., Nopens, I., 2013. Comparison of ozone and HO induced conversion of effluent organic matter (EfOM) using ozonation and $\mathrm{UV} / \mathrm{H}_{2} \mathrm{O}_{2}$ treatment. Water Res. 47 (7), 2387-2398.

Ayache, C., Pidou, M., Croué, J.P., Labanowski, J., Poussade, Y., Tazi-Pain, A., Keller, J., Gernjak, W., 2013. Impact of effluent organic matter on low-pressure membrane fouling in tertiary treatment. Water Res. 47, 2633-2642.

Baken, S., Degryse, F., Verheyen, L., Merckx, R., Smolders, E., 2011. Metal complexation properties of freshwater dissolved organic matter are explained by its aromaticity and by anthropogenic ligands. Environ. Sci. Technol. 45, 2584-2590.

Baker, A., 2001. Fluorescence excitation-emission matrix characterization of some sewage-impacted rivers. Environ. Sci. Technol. 35 (5), 948-953.

Banerjee, S., Pillai, S.C., Falaras, P., O'Shea, K.E., Byrne, J.A., Dionysiou, D.D., 2014. New insights into the mechanism of visible light photocatalysis. J. Phys. Chem. Lett. 5, 2543-2554.

Baquero, F., Martínez, J., Cantón, R., 2008. Antibiotics and antibiotic resistance in water environments. Curr. Opin. Biotechnol. 19 (3), 260-265.

Barker, D.J., Stuckey, D.C., 1999. A review of soluble microbial products (SMP) in wastewater treatment systems. Water Res. 33 (14), 3063-3082.

Barker, D.J., Salvi, S.M., Langenhoff, A.A., Stuckey, D.C., 2000 Soluble microbial products in ABR treating low-strength wastewater. J. Environ. Eng. 126 (3), 239-249.

Baskir, C.I., Hansford, G.S., 1980. Product formation in the continuous culture of microbial populations grown on carbohydrates. Biotechnol. Bioeng. 22 (9), 1857-1875.

Bdour, A.N., Hamdi, M.R., Tarawneh, Z., 2009. Perspectives on sustainable wastewater treatment technologies and reuse options in the urban areas of the Mediterranean region. Desalination 237, 162-174.

Becerra-Castro, C., Lopes, A.R., Vaz-Moreira, I., Silva, E.F., Manaia, C.M., Nunes, O.C., 2015. Wastewater reuse in irrigation: a microbiological perspective on implications in soil fertility and human and environmental health. Environ. Int. 75, 117-135.

Bellona, C., Drewes, J.E., Xu, P., Amy, G., 2004. Factors affecting the rejection of organic solutes during NF/RO treatment - a literature review. Water Res. 38 (12), 2795-2809.

Beltran, F.J., 2004. Ozone Reaction Kinetics for Water and Wastewater Systems. Lewis Publishers. CRC Press.

Bengraïne, K., Marhaba, T.F., 2004. Predicting organic loading in natural water using spectral fluorescent signatures. J. Hazard. Mater. 108 (3), 207-211.

Bixio, D., Thoeye, C., De Koning, J., Joksimovic, D., Savic, D., Wintgens, T., Melin, T., 2006. Wastewater reuse in Europe. Desalination 187, 89-101.

Bixio, D., Thoeye, C., Wintgens, T., Ravazzini, A., Miska, V., Muston, M., Chikurel, H., Aharoni, A., Joksimovic, D., Melin, T., 2008. Water reclamation and reuse: implementation and management issues. Desalination 218, 13-23.

Bolto, B., Abbt-Braun, G., Dixon, D., Eldridge, R., Frimmel, F., Hesse, S., King, S., Toifl, M., 1999. Experimental evaluation of cationic polyelectrolytes for removing natural organic matter from water. Water Sci. Technol. 40 (9), 71-79.

Bolto, B., Dixon, D., Eldridge, R., King, S., Linge, K., 2002a. Removal of natural organic matter by ion exchange. Water Res. 36 (20), 5057-5065.

Bolto, B., Dixon, D., Eldridge, R., King, S., 2002b. Removal of THM precursors by coagulation or ion exchange. Water Res. 36 (20), 5066-5073.

Boxall, A.B., Johnson, P., Smith, E.J., Sinclair, C.J., Stutt, E., Levy, L.S., 2006. Uptake of veterinary medicines from soils into plants. J. Agric. Food Chem. 54 (6), 2288-2297.

Buffle, J., 1988. Complexation Reactions in Aquatic Systems. An Analytical Approach. J. Wiley \& Sons Ltd./Ellis Horwood Ltd, Chichester.

Buzier, R., Tusseau-Vuillemin, M.H., Mouchel, J.M., 2006. Evaluation of DGT as a metal speciation tool in wastewater. Sci. Total Environ. 358, 277-285.

Campbell, P.G., Twiss, M.R., Wilkinson, K.J., 1997. Accumulation of natural organic matter on the surfaces of living cells: implications for the interaction of toxic solutes with aquatic biota. Can. J. Fish. Aquat. Sci. 54 (11), 2543-2554. 
Candela, L., Fabregat, S., Josa, A., Suriol, J., Vigués, N., Mas, J., 2007. Assessment of soil and groundwater impacts by treated urban wastewater reuse. A case study: application in a golf course (Girona, Spain). Sci. Total Environ. 374 (1), 26-35.

Cao, N., Yang, M., Zhang, Y., Hu, J.Y., Ike, M., Hirotsuji, J., Matsui, H., Inoue, D., Sei, K., 2009. Evaluation of wastewater reclamation technologies based on in vitro and in vivo bioassays. Sci. Total Environ. 407 (5), 1588-1597.

Carp, O., Huisman, C.L., Reller, A., 2004. Photoinduced reactivity of titanium dioxide. Prog. Solid State Chem. 32 (1), 33-177.

Carvalho, S.I., Otero, M., Duarte, A.C., Santos, E.B., 2008. Effects of solar radiation on the fluorescence properties and molecular weight of fulvic acids from pulp mill effluents. Chemosphere 71 (8), 1539-1546.

CDPH, 2013. Groundwater Replenishment Reuse Draft Regulations. California Department of Public Health, Sacramento, CA. <http://www.cdph.ca.gov/healthinfo/ environhealth/water/pages/waterrecycling.aspx $>$.

CEN/SABE ENV Team, 2014. Environmental Monitoring Strategy Team. ENV N 301.

Chen, J., Gu, B., LeBoeuf, E.J., Pan, H., Dai, S., 2002. Spectroscopic characterization of the structural and functional properties of natural organic matter fractions. Chemosphere 48 (1), $59-68$.

Cheng, W., Dastgheib, S.A., Karanfil, T., 2005. Adsorption of dissolved natural organic matter by modified activated carbons. Water Res. 39 (11), 2281-2290.

Chevremont, A.C., Farnet, A.M., Sergent, M., Coulomb, B., Boudenne, J.L., 2012. Multivariate optimization of fecal bioindicator inactivation by coupling UV-A and UV-C LEDs. Desalination 285, 219-225.

Chevremont, A.C., Boudenne, J.L., Coulomb, B., Farnet, A.M., 2013. Impact of watering with UV-LED-treated wastewater on microbial and physico-chemical parameters of soil. Water Res. 47, 1971-1982.

Chin, A., Bérubé, P., 2005. Removal of disinfection by-product precursors with ozone-UV advanced oxidation process. Water Res. 39 (10), 2136-2144.

Chu, W.H., Gao, N.Y., Deng, Y., Krasner, S.W., 2010. Precursors of dichloroacetamide, an emerging nitrogenous DBP formed during chlorination or chloramination. Environ. Sci. Technol. 44, 3908-3912.

Chu, W.H., Gao, N.Y., Yin, D.Q., Deng, Y., Templeton, M.R., 2012. Ozone-biological activated carbon integrated treatment for removal of precursors of halogenated nitrogenous disinfection by-products. Chemosphere 86, 1087-1091.

Chu, W., Li, C., Gao, N., Templeton, M.R., Zhang, Y., 2014. Terminating pre-ozonation prior to biological activated carbon filtration results in increased formation of nitrogenous disinfection by-products upon subsequent chlorination. Chemosphere 121, 33-38.

COM, 2011. Proposal for a Directive of the European Parliament and of the Council Amending Directives 2000/60/EC and 2008/ 105/EC as Regards Priority Substances in the Field of Water Policy (31.01.2012), p. 876.

Cornelissen, E., Beerendonk, E., Nederlof, M., van der Hoek, J., Wessels, L., 2009. Fluidized ion exchange (FIX) to control NOM fouling in ultrafiltration. Desalination 236 (1), 334-341.

Crebelli, R., Conti, L., Monarca, S., Feretti, D., Zerbini, I., Zani, C., Veschetti, E., Cutilli, D., Ottaviani, M., 2005. Genotoxicity of the disinfection by-products resulting from peracetic acid- or hypochlorite-disinfected sewage wastewater. Water Res. 39 (6), 1105-1113.

Croué, J., Violleau, D., Bodaire, C., Legube, B., 1999. Removal of hydrophobic and hydrophilic constituents by anion exchange resin. Water Sci. Technol. 40 (9), 207-214.
Danielsson, L.G., 1982. On the use of filters for distinguishing between dissolved and particulate fractions in natural waters. Water Res. 16 (2), 179-182.

Dantas, R.F., Contreras, S., Sans, C., Esplugas, S., 2008. Sulfamethoxazole abatement by means of ozonation. J. Hazard. Mater. 150 (3), 790-794.

Daughton, C.G., Ternes, T.A., 1999. Pharmaceuticals and personal care products in the environment: agents of subtle change? Environ. Health Perspect. 107 (Suppl. 6), 907-938.

De la Cruz, N., Gimenez, J., Esplugas, S., Grandjean, D., De Alencastro, L., Pulgarin, C., 2012. Degradation of 32 emergent contaminants by UV and neutral photo-Fenton in domestic wastewater effluent previously treated by activated sludge. Water Res. 46 (6), 1947-1957.

De Schamphelaere, K.A., Vasconcelos, F.M., Tack, F.M., Allen, H.E., Janssen, C.R., 2004. Effect of dissolved organic matter source on acute copper toxicity to Daphnia magna. Environ. Toxicol. Chem. 23 (5), 1248-1255.

Delay, M., Schwegmann, H., Frimmel, F.H., 2015. Nanoparticles and refractory organic matter: interactions and consequences. J. Environ. Chem. Eng. (in press).

Domenjoud, B., Tatari, C., Esplugas, S., Baig, S., 2011. Ozone-based processes applied to municipal secondary effluents. Ozone Sci. Eng. 33, 243-249.

Dong, M.M., Mezyk, S.P., Rosario-Ortiz, F.L., 2010. Reactivity of effluent organic matter (EfOM) with hydroxyl radical as a function of molecular weight. Environ. Sci. Technol. 44 (15), $5714-5720$

Drewes, J.E., Croué, J.P., 2002. New approaches for structural characterization of organic matter in drinking water and wastewater effluents. Water Sci. Technol. Water Supply 2, $1-10$.

Drewes, J.E., Fox, P., 2000. Effect of drinking water sources on reclaimed water quality in water reuse systems. Water Environ. Res. 353-362.

Drewes, J.E., Reinhard, M., Fox, P., 2003. Comparing microfiltration-reverse osmosis and soil-aquifer treatment for indirect potable reuse of water. Water Res. 37 (15), 3612-3621.

EC-European Commision, 2003. Technical Guidance Document on Risk Assessment, Part II, EC and European Chemicals Bureau. Joint Research Centre, Ispra, Italy.

Erdei, L., Arecrachakul, N., Vigneswaran, S., 2008. A combined photocatalytic slurry reactor-immersed membrane module system for advanced wastewater treatment. Sep. Purif. Technol. 62, 382-388.

Escher, B.I., Bramaz, N., Ort, C., 2009. JEM spotlight: monitoring the treatment efficiency of a full scale ozonation on a sewage treatment plant with a mode-of-action based test battery. J. Environ. Monit. 11 (10), 1836-1846.

Esparza-Soto, M., Núñez-Hernández, S., Fall, C., 2011. Spectrometric characterization of effluent organic matter of a sequencing batch reactor operated at three sludge retention times. Water Res. 45, 6555-6563.

Etchepare, R., van der Hoek, J.P., 2014. Health risk assessment of organic micropollutants in greywater for potable reuse. Water Res. 1-13. http://dx.doi.org/10.1016/j.watres.2014.10.048.

Fabris, R., Chow, C.W., Drikas, M., Eikebrokk, B., 2008. Comparison of NOM character in selected Australian and Norwegian drinking waters. Water Res. 42 (15), 4188-4196.

Fatta-Kassinos, D., Kalavrouziotis, I., Koukoulakis, P., Vasquez, M., 2011a. The risks associated with wastewater reuse and xenobiotics in the agroecological environment. Sci. Total Environ. 409 (19), 3555-3563.

Fatta-Kassinos, D., Meric, S., Nikolaou, A., 2011b. Pharmaceutical residues in environmental waters and wastewater: current state of knowledge and future research. Anal. Bioanal. Chem. 399 (1), 251-275. 
Fatta-Kassinos, D., Vasquez, M., Kümmerer, K., 2011c. Transformation products of pharmaceuticals in surface waters and wastewater formed during photolysis and advanced oxidation processes - degradation, elucidation of byproducts and assessment of their biological potency. Chemosphere 85 (5), 693-709.

Fearing, D.A., Banks, J., Guyetand, S., Monfort Eroles, C., Jefferson, B., Wilson, D., Hillis, P., Campbell, A.T., Parsons, S.A., 2004. Combination of ferric and MIEX ${ }^{\mathbb{B}}$ for the treatment of a humic rich water. Water Res. 38 (10), 2551-2558.

Filloux, E., Labanowski, J., Croué, J.P., 2012a. Understanding the fouling of UF/MF hollow fibres of biologically treated wastewaters using advanced EfOM characterization and statistical tools. Bioresour. Technol. 118, 460-468.

Filloux, E., Gallard, H., Croué, J., 2012b. Identification of effluent organic matter fractions responsible for low-pressure membrane fouling. Water Res. 46 (17), 5531-5540.

Frimmel, F., 1998. Characterization of natural organic matter as major constituents in aquatic systems. J. Contam. Hydrol. 35 (1), 201-216.

Frimmel, F., Abbt-Braun, G., 1999. Basic characterization of reference NOM from central Europe - similarities and differences. Environ. Int. 25 (2), 191-207.

Frimmel, F.H., Christman, R.F., 1988. Humic Substances and Their Role in the Environment. John Wiley and Sons Ltd., Chichester, West Sussex.

Fu, P.L., Symons, J.M., 1990. Removing aquatic organic substances by anion exchange resins. J. Am. Water Works Assoc. 82 (10), 70-77.

Fujioka, T., Khan, S.J., McDonald, J.A., Henderson, R.K., Poussade, Y., Drewes, J.E., Nghiem, L.D., 2013. Effects of membrane fouling on $\mathrm{N}$-nitrosamine rejection by nanofiltration and reverse osmosis membranes. J. Membr. Sci. 427, 311-319.

Gaffney, J.S., Marley, N.A., Clark, S.B., 1996. Humic and fulvic acids and organic colloidal materials in the environment. In: Humic and Fulvic Acids: Isolation, Structure, and Environmental Role. American Chemical Society, Washington, D.C.

Galvez, F., Donini, A., Playle, R.C., Smith, D.S., O'Donnell, M.J., Wood, C.M., 2008. A matter of potential concern: natural organic matter alters the electrical properties of fish gills. Environ. Sci. Technol. 42 (24), 9385-9390.

Gerrity, D., Gamage, S., Holady, J.C., Mawhinney, D.B., Quiñones, O., Trenholm, R.A., Snyder, S.A., 2011. Pilot-scale evaluation of ozone and biological activated carbon for trace organic contaminant mitigation and disinfection. Water Res. 45, 2155-2165.

Gerrity, D., Pecson, B., Trussell, R.S., Trussell, R.R., 2013. Potable reuse treatment trains throughout the world. J. Water Supply Res. Technol.-AQUA 62, 321-338.

Ghabbour, E.A., Davies, G., 2001. Humic Substances: Structures, Models and Functions. Royal Society of Chemistry.

Glover, C.N., Wood, C.M., 2005. Accumulation and elimination of silver in Daphnia magna and the effect of natural organic matter. Aquat. Toxicol. 73 (4), 406-417.

Glover, C.N., Pane, E.F., Wood, C.M., 2005. Humic substances influence sodium metabolism in the freshwater crustacean Daphnia magna. Physiol. Biochem. Zool. 78 (3), 405-416.

Gong, J., Liu, Y., Sun, X., 2008. $\mathrm{O}_{3}$ and $\mathrm{UV} / \mathrm{O}_{3}$ oxidation of organic constituents of biotreated municipal wastewater. Water Res. 42 (4), 1238-1244.

Gonsior, M., Zwartjes, M., Cooper, W.J., Song, W., Ishida, K.P., Tseng, L.Y., Jeung, M.K., Rosso, D., Hertkorn, N., SchmittKopplin, P., 2011. Molecular characterization of effluent organic matter identified by ultrahigh resolution mass spectrometry. Water Res. 45, 2943-2953.

Gonzales, S., Peña, A., Rosario-Ortiz, F.L., 2012. Examining the role of effluent organic matter components on the decomposition of ozone and formation of hydroxyl radicals in wastewater. Ozone Sci. Eng. 34, 42-48.

González, O., Justo, A., Bacardit, J., Ferrero, E., Malfeito, J.J., Sans, C., 2013. Characterization and fate of effluent organic matter treated with UV/ $\mathrm{H}_{2} \mathrm{O}_{2}$ and ozonation. Chem. Eng. J. 226, 402-408.

Goslan, E.H., Voros, S., Banks, J., Wilson, D., Hillis, P., Campbell, A.T., Parsons, S.A., 2004. A model for predicting dissolved organic carbon distribution in a reservoir water using fluorescence spectroscopy. Water Res. 38 (3), 783-791.

Goslan, E.H., Gurses, F., Banks, J., Parsons, S.A., 2006. An investigation into reservoir NOM reduction by UV photolysis and advanced oxidation processes. Chemosphere 65 (7), 1113-1119.

Gur-Reznik, S., Katz, I., Dosoretz, C.G., 2008. Removal of dissolved organic matter by granular-activated carbon adsorption as a pretreatment to reverse osmosis of membrane bioreactor effluents. Water Res. 42 (6), 1595-1605.

Haddad, T., Baginska, E., Kümmerer, K., 2015. Transformation products of antibiotic and cytostatic drugs in the aquatic cycle that result from effluent treatment and abiotic/biotic reactions in the environment: an increasing challenge calling for revisiting measures at the beginning-of-the-pipe. Water Res. 72, 75-126.

Heberer, T., 2002. Occurrence, fate, and removal of pharmaceutical residues in the aquatic environment: a review of recent research data. Toxicol. Lett. 131 (1-2), 5-17.

Hedges, J., Eglinton, G., Hatcher, P., Kirchman, D., Arnosti, C., Derenne, S., Evershed, R., Kögel-Knabner, I., De Leeuw, J., Littke, R., 2000. The molecularly-uncharacterized component of nonliving organic matter in natural environments. Org. Geochem. 31 (10), 945-958.

Henderson, R.K., Baker, A., Parsons, S.A., Jefferson, B., 2008. Characterisation of algogenic organic matter extracted from cyanobacteria, green algae and diatoms. Water Res. 42 (13), 3435-3445.

Henderson, R.K., Subhi, N., Antony, A., Khan, S.J., Murphy, K.R., Leslie, G.L., Chenb, Vicki, Stuetza, Richard M., Le-Clech, Pierre, 2011. Evaluation of effluent organic matter fouling in ultrafiltration treatment using advanced organic characterisation techniques. J. Membr. Sci. 382, 50-59.

Her, N., Amy, G., Park, H., Song, M., 2004. Characterizing algogenic organic matter $(\mathrm{AOM})$ and evaluating associated NF membrane fouling. Water Res. 38 (6), 1427-1438.

Herrmann, J., Guillard, C., Pichat, P., 1993. Heterogeneous photocatalysis: an emerging technology for water treatment. Catal. Today 17 (1), 7-20.

Ho, D.P., Vigneswaran, S., Ngo, H.H., 2010. Integration of photocatalysis and microfiltration in removing effluent organic matter from treated sewage effluent. Sep. Sci. Technol. 45, 155-162.

Hollender, J., Zimmermann, S.G., Koepke, S., Krauss, M., McArdell, C.S., Ort, C., Singer, H., von Gunten, U., Siegrist, H., 2009. Elimination of organic micropollutants in a municipal wastewater treatment plant upgraded with a full-scale postozonation followed by sand filtration. Environ. Sci. Technol. $43,7862-7869$.

Hua, G., Reckhow, D.A., 2007. Characterization of disinfection byproduct precursors based on hydrophobicity and molecular size. Environ. Sci. Technol. 41 (9), 3309-3315.

Huang, W., Chen, L., Peng, H., 2004. Effect of NOM characteristics on brominated organics formation by ozonation. Environ. Int. 29 (8), 1049-1055.

Huang, X., Leal, M., Li, Q., 2008. Degradation of natural organic matter by $\mathrm{TiO}_{2}$ photocatalytic oxidation and its effect on fouling of low-pressure membranes. Water Res. 42 (4), 1142-1150. 
Huang, X., Meng, Y., Liang, P., Qian, Y., 2007. Operational conditions of a membrane filtration reactor coupled with photocatalytic oxidation. Sep. Purif. Technol. 55, 165-172.

Hudson, N., Baker, A., Reynolds, D., 2007. Fluorescence analysis of dissolved organic matter in natural, waste and polluted waters - a review. River Res. Appl. 23 (6), 631-649.

Humbert, H., Gallard, H., Suty, H., Croué, J., 2008. Natural organic matter (NOM) and pesticides removal using a combination of ion exchange resin and powdered activated carbon (PAC). Water Res. 42 (6), 1635-1643.

Imai, A., Fukushima, T., Matsushige, K., Kim, Y., Choi, K., 2002. Characterization of dissolved organic matter in effluents from wastewater treatment plants. Water Res. 36 (4), 859-870.

Ivnitsky, H., Katz, I., Minz, D., Shimoni, E., Chen, Y., Tarchitzky, J., Semiat, R., Dosoretz, C., 2005. Characterization of membrane biofouling in nanofiltration processes of wastewater treatment. Desalination 185 (1), 255-268.

Jarusutthirak, C., Amy, G., 2007. Understanding soluble microbial products (SMP) as a component of effluent organic matter (EfOM). Water Res. 41 (12), 2787-2793.

Jarusutthirak, C., Amy, G., Croué, J., 2002. Fouling characteristics of wastewater effluent organic matter (EfOM) isolates on NF and UF membranes. Desalination 145 (1), 247-255.

Jeong, K., Lee, D.S., Kim, D.G., Ko, S.O., 2014. Effects of ozonation and coagulation on effluent organic matter characteristics and ultrafiltration membrane fouling. J. Environ. Sci. 26, 1325-1331.

Jin, G., Yongzhen, P., Jianhua, G., Juan, M., Wei, W., Baogui, W., 2011. Dissolved organic matter in biologically treated sewage effluent (BTSE): characteristics and comparison. Desalination 278 (1), 365-372.

Johnson, C.J., Singer, P.C., 2004. Impact of a magnetic ion exchange resin on ozone demand and bromate formation during drinking water treatment. Water Res. 38 (17), 3738-3750.

Joseph, L., Flora, J.R., Park, Y., Badawy, M., Saleh, H., Yoon, Y., 2012. Removal of natural organic matter from potential drinking water sources by combined coagulation and adsorption using carbon nanomaterials. Sep. Purif. Technol. 95, 64-72.

Kalavrouziotis, I.K., Kokkinos, P., Oron, G., Fatone, F., Bolzonella, D., Vatyliotou, M., Fatta-Kassinos, D., Koukoulakis, P.H., Varnavas, S.P., 2013. Current status in wastewater treatment, reuse and research in some Mediterranean countries. Desalin. Water Treat. http:// dx.doi.org/10.1080/19443994.2013.860632.

Kalkan, C., Yapsakli, K., Mertoglu, B., Tufan, D., Saatci, A., 2011. Evaluation of biological activated carbon (BAC) process in wastewater treatment secondary effluent for reclamation purposes. Desalination 265, 266-273.

Keen, O.S., McKay, G., Mezyk, S.P., Linden, K.G., RosarioOrtiz, F.L., 2014. Identifying the factors that influence the reactivity of effluent organic matter with hydroxyl radicals. Water Res. 50, 408-419.

Kim, H., Dempsey, B.A., 2012. Comparison of two fractionation strategies for characterization of wastewater effluent organic matter and diagnosis of membrane fouling. Water Res. 46 (11) 3714-3722.

Kim, S., Chen, J.P., Ting, Y., 2002. Study on feed pretreatment for membrane filtration of secondary effluent. Sep. Purif. Technol. 29 (2), 171-179.

Klavarioti, M., Mantzavinos, D., Kassinos, D., 2009. Removal of residual pharmaceuticals from aqueous systems by advanced oxidation processes. Environ. Int. 35 (2), 402-417.

Knauer, K., Buffle, J., 2001. Adsorption of fulvic acid on algal surfaces and its effect on carbon uptake. J. Phycol. 37 (1), $47-51$.

Köck-Schulmeyer, M., Ginebreda, A., Postigo, C., López-Serna, R., Pérez, S., Brix, R., Llorca, M., de Alda, M.L., Petrović, M.,
Munné, A., Tirapu, L., Barceló, D., 2011. Wastewater reuse in Mediterranean semi-arid areas: the impact of discharges of tertiary treated sewage on the load of polar micro pollutants in the Llobregat river (NE Spain). Chemosphere 82, 670-678.

Korak, J.A., Dotson, A.D., Summers, R.S., Rosario-Ortiz, F.L., 2014. Critical analysis of commonly used fluorescence metrics to characterize dissolved organic matter. Water Res. 49, 327-338.

Korshin, G., Chow, C.W., Fabris, R., Drikas, M., 2009. Absorbance spectroscopy-based examination of effects of coagulation on the reactivity of fractions of natural organic matter with varying apparent molecular weights. Water Res. 43 (6), $1541-1548$

Kosmala, A., Charvet, S., Roger, M., Faessel, B., 1999. Impact assessment of a wastewater treatment plant effluent using instream invertebrates and the Ceriodaphnia dubia chronictoxicity test. Water Res. 33 (1), 266-278.

Krasner, S.W., Westerhoff, P., Chen, B., Rittmann, B.E., Nam, S.N., Amy, G., 2009. Impact of wastewater treatment processes on organic carbon, organic nitrogen, and DBP precursors in effluent organic matter. Environ. Sci. Technol. 43, 2911-2918.

Krauss, M., Longrée, P., Dorusch, F., Ort, C., Hollender, J., 2009. Occurrence and removal of $\mathrm{N}$-nitrosamines in wastewater treatment plants. Water Res. 43, 4381-4391.

Kuo, W., Sneve, M.A., Parkin, G.F., 1996. Formation of soluble microbial products during anaerobic treatment. Water Environ. Res. 279-285.

Lahnsteiner, J., Lempert, G., 2007. Water management in Windhoek, Namibia. Water Sci. Technol. 55 (1-2), 441-448.

Lamelas, C., Wilkinson, K.J., Slaveykova, V.I., 2005. Influence of the composition of natural organic matter on $\mathrm{Pb}$ bioavailability to microalgae. Environ. Sci. Technol. 39 (16), 6109-6116.

Lamelas, C., Pinheiro, J.P., Slaveykova, V.I., 2009. Effect of humic acid on $\mathrm{Cd}$ (II), $\mathrm{Cu}$ (II), and $\mathrm{Pb}$ (II) uptake by freshwater algae: kinetic and cell wall speciation considerations. Environ. Sci. Technol. 43 (3), 730-735.

Lazarova, V., Savoye, P., 2004. Technical and sanitary aspects of wastewater disinfection by UV irradiation for landscape irrigation. Water Sci. Technol. 50 (2), 203-209.

Le-Clech, P., Chen, V., Fane, T.A., 2006. Fouling in membrane bioreactors used in wastewater treatment. J. Membr. Sci. 284 (1), 17-53.

Le-Minh, N., Khan, S., Drewes, J., Stuetz, R., 2010. Fate of antibiotics during municipal water recycling treatment processes. Water Res. 44 (15), 4295-4323.

Lee, S., Kwon, B., Sun, M., Cho, J., 2005. Characterizations of NOM included in NF and UF membrane permeates. Desalination 173 (2), 131-142.

Leenheer, J.A., 1981. Comprehensive approach to preparative isolation and fractionation of dissolved organic carbon from natural waters and wastewaters. Environ. Sci. Technol. 15 (5), 578-587.

Leenheer, J., 2004. Comprehensive assessment of precursors, diagenesis, and reactivity to water treatment of dissolved and colloidal organic matter. Water Supply 4 (4), 1-9.

Leenheer, J., 2009. Systematic approaches to comprehensive analyses of natural organic matter. Ann. Environ. Sci. 3, $1-130$.

Leenheer, J.A., Croué, J., 2003. Peer reviewed: characterizing aquatic dissolved organic matter. Environ. Sci. Technol. 37 (1), 18A-26A.

Legrini, O., Oliveros, E., Braun, A., 1993. Photochemical processes for water treatment. Chem. Rev. 93 (2), 671-698.

Leverenz, H.L., Tchobanoglous, G., Asano, T., 2011. Direct potable reuse: a future imperative. J. Water Reuse Desalin. 1, 2-10.

Levine, A.D., Tchobanoglous, G., Asano, T., 1985. Characterization of the size distribution of contaminants in wastewater: 
treatment and reuse implications. J. Water Pollut. Control Fed. 57 (7), 805-816.

Li, W., Nanaboina, V., Zhou, Q., Korshin, G.V., 2012. Effects of Fenton treatment on the properties of effluent organic matter and their relationships with the degradation of pharmaceuticals and personal care products. Water Res. 46, 403-412.

Li, W., Nanaboina, V., Zhou, Q., Korshin, G.V., 2013. Changes of excitation/emission matrixes of wastewater caused by Fenton- and Fenton-like treatment and their associations with the generation of hydroxyl radicals, oxidation of effluent organic matter and degradation of trace-level organic pollutants. J. Hazard. Mater. 244-245, 698-708.

Liang, S., Liu, C., Song, L., 2007. Soluble microbial products in membrane bioreactor operation: behaviors, characteristics, and fouling potential. Water Res. 41 (1), 95-101.

Linlin, W., Xuan, Z., Meng, Z., 2011. Removal of dissolved organic matter in municipal effluent with ozonation, slow sand filtration and nanofiltration as high quality pre-treatment option for artificial groundwater recharge. Chemosphere 83 (5), 693-699.

Litter, M., 2005. Introduction to photochemical advanced oxidation processes for water treatment. Environ. Photochem. Part II 325-366.

Liu, S., Lim, M., Fabris, R., Chow, C., Chiang, K., Drikas, M., Amal, R., 2008. Removal of humic acid using $\mathrm{TiO}_{2}$ photocatalytic process - fractionation and molecular weight characterisation studies. Chemosphere 72 (2), 263-271.

Liu, S., Lim, M., Fabris, R., Chow, C., Drikas, M., Amal, R., 2010. Comparison of photocatalytic degradation of natural organic matter in two Australian surface waters using multiple analytical techniques. Org. Geochem. 41 (2), 124-129.

López-Serna, R., Postigo, C., Blanco, J., Pérez, S., Ginebreda, A., de Alda, M.L., Petrović, M., Munné, A., Barceló, D., 2012. Assessing the effects of tertiary treated wastewater reuse on the presence emerging contaminants in a Mediterranean river (Llobregat, NE Spain). Environ. Sci. Pollut. Res. 19 (4), 1000-1012.

Louis, Y., Pernet-Coudrier, B., Varrault, G., 2014. Implications of effluent organic matter and its hydrophilic fraction on zinc(II) complexation in rivers under strong urban pressure: aromaticity as an inaccurate indicator of DOM-metal binding. Sci. Total Environ. 490, 830-837.

Ma, H., Allen, H.E., Yin, Y., 2001. Characterization of isolated fractions of dissolved organic matter from natural waters and a wastewater effluent. Water Res. 35 (4), 985-996.

Malato, S., Fernández-Ibáñez, P., Maldonado, M., Blanco, J., Gernjak, W., 2009. Decontamination and disinfection of water by solar photocatalysis: recent overview and trends. Catal. Today 147 (1), 1-59.

Malchi, T., Maor, Y., Tadmor, G., Shenker, M., Chefetz, B., 2014. Irrigation of root vegetables with treated wastewater: evaluating uptake of pharmaceuticals and the associated human health risks. Environ. Sci. Technol. 48 (16), 9325-9333.

Marhaba, T.F., Pu, Y., Bengraine, K., 2003. Modified dissolved organic matter fractionation technique for natural water. J. Hazard. Mater. 101 (1), 43-53.

Matilainen, A., Sillanpää, M., 2010. Removal of natural organic matter from drinking water by advanced oxidation processes. Chemosphere 80 (4), 351-365.

Matilainen, A., Vepsäläinen, M., Sillanpää, M., 2010. Natural organic matter removal by coagulation during drinking water treatment: a review. Adv. Colloid Interface Sci. 159 (2), 189-197.

McCreary, J.J., Snoeyink, V.L., 1980. Characterization and activated carbon adsorption of several humic substances. Water Res. 14 (2), 151-160.
McDonald, S., Bishop, A.G., Prenzler, P.D., Robards, K., 2004. Analytical chemistry of freshwater humic substances. Anal. Chim. Acta 527 (2), 105-124.

McKnight, D.M., Boyer, E.W., Westerhoff, P.K., Doran, P.T., Kulbe, T., Andersen, D.T., 2001. Spectrofluorometric characterization of dissolved organic matter for indication of precursor organic material and aromaticity. Limnol. Oceanogr. 46 (1), 38-48.

Meier, J., Melin, T., 2005. Wastewater reclamation by the PAC-NF process. Desalination 178 (1), 27-40.

Meinelt, T., Schreckenbach, K., Knopf, K., Wienke, A., Stüber, A., Steinberg, C.E., 2004. Humic substances affect physiological condition and sex ratio of swordtail (Xiphophorus helleri Heckel). Aquat. Sci. 66 (2), 239-245.

Meinelt, T., Paul, A., Phan, T.M., Zwirnmann, E., Krüger, A., Wienke, A., Steinberg, C.E., 2007. Reduction in vegetative growth of the water mold Saprolegnia parasitica (Coker) by humic substance of different qualities. Aquat. Toxicol. 83 (2), 93-103.

Melin, T., Jefferson, B., Bixio, D., Thoeye, C., De Wilde, W., De Koning, J., van der Graaf, J., Wintgens, T., 2006. Membrane bioreactor technology for wastewater treatment and reuse. Desalination 187, 271-282.

Meng, F., Zhou, Z., Ni, B.J., Zheng, X., Huang, G., Jia, X., Li, S., Xiong, Y., Kraume, M., 2011. Characterization of the sizefractionated biomacromolecules: tracking their role and fate in a membrane bioreactor. Water Res. 45, 4661-4671.

Michael, I., Hapeshi, E., Osorio, V., Perez, S., Petrovic, M., Zapata, A., Malato, S., Barceló, D., Fatta-Kassinos, D., 2012a. Solar photocatalytic treatment of trimethoprim in four environmental matrices at a pilot scale: transformation products and ecotoxicity evaluation. Sci. Total Environ. 430, 167-173.

Michael, I., Hapeshi, E., Michael, C., Varela, A., Kyriakou, S., Manaia, C., Fatta-Kassinos, D., 2012b. Solar photo-Fenton process on the abatement of antibiotics at a pilot scale: degradation kinetics, ecotoxicity and phytotoxicity assessment and removal of antibiotic resistant enterococci. Water Res. 46 (17), 5621-5634.

Michael, I., Rizzo, L., McArdell, C., Manaia, C., Merlin, C., Schwartz, T., Dagot, C., Fatta-Kassinos, D., 2013. Urban wastewater treatment plants as hotspots for the release of antibiotics in the environment: a review. Water Res. 47 (3), 957-995.

Moncayo-Lasso, A., Pulgarin, C., Benítez, N., 2008. Degradation of DBPs' precursors in river water before and after slow sand filtration by photo-Fenton process at pH 5 in a solar CPC reactor. Water Res. 42 (15), 4125-4132.

Mosteo, R., Miguel, N., Martin-Muniesa, S., Ormad, M.P., Ovelleiro, J.L., 2009. Evaluation of trihalomethane formation potential in function of oxidation processes used during the drinking water production process. J. Hazard. Mater. 172 (2), 661-666.

Mozia, S., 2010. Photocatalytic membrane reactors (PMRs) in water and wastewater treatment. A review. Sep. Purif. Technol. 73, 71-91.

Mueses, M.A., Machuca-Martinez, F., Li Puma, G., 2013. Effective quantum yield and reaction rate model for evaluation of photocatalytic degradation of water contaminants in heterogeneous pilot-scale solar photoreactors. Chem. Eng. J. 215, 937-947.

Muñoz, I., Gómez-Ramos, M.J., Agüera, A., Fernández-Alba, A.R., García-Reyes, J.F., Molina-Díaz, A., 2009. Chemical evaluation of contaminants in wastewater effluents and the environmental risk of reusing effluents in agriculture. TrAC Trends Anal. Chem. 28 (6), 676-694.

Muresan, B., Pernet-Coudrier, B., Cossa, D., Varrault, G., 2011. Measurement and modeling of mercury complexation by dissolved organic matter isolates from freshwater and 
effluents of a major wastewater treatment plant. Appl. Geochem. 26, 2057-2063.

Murray, A., Ray, I., 2010. Wastewater for agriculture: a reuseoriented planning model and its application in peri-urban China. Water Res. 44 (5), 1667-1679.

Namkung, E., Rittmann, B.E., 1986. Soluble microbial products (SMP) formation kinetics by biofilms. Water Res. 20 (6), 795-806.

Nasser, A.M., Paulman, H., Sela, O., Ktaitzer, T., Cikurel, H., Zuckerman, I., Meir, A., Aharoni, A., Adin, A., 2006. UV disinfection of wastewater effluents for unrestricted irrigation. Water Sci. Technol. 54 (3), 83-88.

Newcombe, G., 1999. Charge vs. porosity - some influences on the adsorption of natural organic matter (NOM) by activated carbon. Water Sci. Technol. 40 (9), 191-198.

Ng, T., Chow, A.T., Wong, P., 2014. Dual roles of dissolved organic matter in photo-irradiated Fe (III)-contained waters. J. Photochem. Photobiol. A: Chem. 290, 116-124.

Nguyen, S.T., Roddick, F.A., 2010. Effects of ozonation and biological activated carbon filtration on membrane fouling in ultrafiltration of an activated sludge effluent. J. Membr. Sci. $363,271-277$.

Nguyen, T.V., Zhang, R., Vigneswaran, S., Ngo, H.H., Kandasamy, J., Mathes, P., 2011. Removal of organic matter from effluents by magnetic ion exchange $\left(\right.$ MIEX $\left.^{\circledR}\right)$. Desalination 276, 96-102.

Nikolaou, A., Meric, S., Fatta, D., 2007. Occurrence patterns of pharmaceuticals in water and wastewater environments. Anal. Bioanal. Chem. 387 (4), 1225-1234.

O'Loughlin, E., Chin, Y., 2001. Effect of detector wavelength on the determination of the molecular weight of humic substances by high-pressure size exclusion chromatography. Water Res. 35 (1), 333-338.

Park, S., Yoon, T., 2007. The effects of iron species and mineral particles on advanced oxidation processes for the removal of humic acids. Desalination 208 (1-3), 181-191.

Parkinson, A., Roddick, F., Hobday, M., 2003. UV photooxidation of NOM: issues related to drinking water treatment. Aqua 52, 577-586.

Parsons, S.A., Jefferson, B., Goslan, E.H., Jarvis, P.R., Fearing, D.A., 2004. Natural organic matter - the relationship between character and treatability. Water Sci. Technol. Water Supply 4 (5-6), 43-48.

Pedrero, F., Kalavrouziotis, I., Alarcón, J.J., Koukoulakis, P., Asano, T., 2010. Use of treated municipal wastewater in irrigated agriculture - review of some practices in Spain and Greece. Agric. Water Manag. 97 (9), 1233-1241.

Pehlivanoglu-Mantasa, E., Hawley, E.L., Deeb, R.A., Sedlak, D.V., 2006. Formation of nitrosodimethylamine (NDMA) during chlorine disinfection of wastewater effluents prior to use in irrigation systems. Water Res. 40, 341-347.

Pérez-Moya, M., Graells, M., Castells, G., Amigó, J., Ortega, E., Buhigas, G., Pérez, L.M., Mansilla, H.D., 2010. Characterization of the degradation performance of the sulfamethazine antibiotic by photo-Fenton process. Water Res. 44 (8), 2533-2540.

Pernet-Coudrier, B., Clouzot, L., Varrault, G., TusseauVuillemin, M., Verger, A., Mouchel, J., 2008. Dissolved organic matter from treated effluent of a major wastewater treatment plant: characterization and influence on copper toxicity. Chemosphere 73 (4), 593-599.

Petrović, M., Barceló, D., 2006. Liquid chromatography-mass spectrometry in the analysis of emerging environmental contaminants. Anal. Bioanal. Chem. 385 (3), 422-424.

Petrović, M., Gros, M., Barceló, D., 2006. Multi-residue analysis of pharmaceuticals in wastewater by ultra-performance liquid chromatography-quadrupole-time-of-flight mass spectrometry. J. Chromatogr. A 1124 (1), 68-81.
Petrović, M., Gros, M., Barceló, D., 2007. Multi-residue analysis of pharmaceuticals using LC-tandem MS and LC-hybrid MS. Compr. Anal. Chem. 50, 157-183.

Pisani, P., Menge, J.G., 2013. Direct potable reclamation in Windhoek: a critical review of the design philosophy of new Goreangab drinking water reclamation plant. Water Sci. Technol. Water Supply 13 (2), 214-226.

Pramanik, B.K., Roddick, F.A., Fan, L., 2015. A comparative study of biological activated carbon, granular activated carbon and coagulation feed pre-treatment for improving microfiltration performance in wastewater reclamation. J. Membr. Sci. 475, 147-155.

PUB, 2012. NEWater: the 3rd National Tap. Singapore Public Utilities Board. <http://www.pub.gov.sg/water/newater/ Pages/default.aspx $>$.

Puspita, P., Roddick, F., Porter, N., 2015. Efficiency of sequential ozone and UV-based treatments for the treatment of secondary effluent. Chem. Eng. J. 268, 337-347.

Quaranta, M.L., Mendes, M.D., MacKay, A.A., 2012. Similarities in effluent organic matter characteristics from Connecticut wastewater treatment plants. Water Res. 46 (2), 284-294.

Reungoat, J., Macova, M., Escher, B.I., Carswell, S., Mueller, J.F., Keller, J., 2010. Removal of micropollutants and reduction of biological activity in a full scale reclamation plant using ozonation and activated carbon filtration. Water Res. 44, 625-637.

Reungoat, J., Escher, B.I., Macova, M., Argaud, F.X., Gernjak, W., Keller, J., 2012. Ozonation and biological activated carbon filtration of wastewater treatment plant effluents. Water Res. $46,863-872$.

Richardson, S.D., 2003. Disinfection by-products and other emerging contaminants in drinking water. TrAC Trends Anal. Chem. 22 (10), 666-684.

Richardson, S.D., Ternes, T.A., 2005. Water analysis: emerging contaminants and current issues. Anal. Chem. 77 (12), 3807-3838.

Rizzo, L., 2011. Bioassays as a tool for evaluating advanced oxidation processes in water and wastewater treatment. Water Res. 45, 4311-4340.

Rizzo, L., Manaia, C., Merlin, C., Schwartz, T., Dagot, C., Ploy, M., Michael, I., Fatta-Kassinos, D., 2013. Urban wastewater treatment plants as hotspots for antibiotic resistant bacteria and genes spread into the environment: a review. Sci. Total Environ. 447, 345-360.

Rodriguez, C., Buynder, P.V., Lugg, R., Blair, P., Devine, B., Cook, A., Weinstein, P., 2009. Indirect potable reuse: a sustainable water supply alternative. Int. J. Environ. Res. Public Health 6, 1174-1209.

Rodríguez-Chueca, J., Polo-López, M.I., Mosteo, R., Ormad, M.P., Fernández-Ibánez, P., 2014. Disinfection of real and simulated urban wastewater effluents using a mild solar photo-Fenton. Appl. Catal. B: Environ. 150-151, 619-629.

Rosal, R., Rodríguez, A., Perdigón-Melón, J.A., Petre, A., GarcíaCalvo, E., 2009. Oxidation of dissolved organic matter in the effluent of a sewage treatment plant using ozone combined with hydrogen peroxide $\left(\mathrm{O}_{3} / \mathrm{H}_{2} \mathrm{O}_{2}\right)$. Chem. Eng. J. 149 (1), 311-318.

Rosario-Ortiz, F.L., Mezyk, S.P., Doud, D.F., Snyder, S.A., 2008a. Quantitative correlation of absolute hydroxyl radical rate constants with non-isolated effluent organic matter bulk properties in water. Environ. Sci. Technol. 42 (16), 5924-5930.

Rosario-Ortiz, F.L., Mezyk, S.P., Wert, E.C., Doud, D.F., Singh, M.K., Xin, M., Baik, S., Snyder, S.A., 2008b. Effect of ozone oxidation on the molecular and kinetic properties of effluent organic matter. J. Adv. Oxid. Technol. 11 (3), 529-535.

Rosenberger, S., Laabs, C., Lesjean, B., Gnirss, R., Amy, G., Jekel, M., Schrotter, J., 2006. Impact of colloidal and soluble organic material on membrane performance in membrane 
bioreactors for municipal wastewater treatment. Water Res. 40 (4), 710-720.

Ruiken, C., Breuer, G., Klaversma, E., Santiago, T., van Loosdrecht, M., 2013. Sieving wastewater - cellulose recovery, economic and energy evaluation. Water Res. 47 (1), 43-48.

Sánchez-Marín, P., Bellas, J., Mubiana, V.K., Lorenzo, J.I., Blust, R., Beiras, R., 2011. Pb uptake by the marine mussel Mytilus sp. interactions with dissolved organic matter. Aquat. Toxicol. 102 (1), 48-57.

Santos, D.C., Silva, L., Albuquerque, A., Simões, A., Gomes, A.C., 2013. Biodegradability enhancement and detoxification of cork processing wastewater molecular size fractions by ozone. Bioresour. Technol. 147, 143-151.

Sarathy, V., Allen, H.E., 2005. Copper complexation by dissolved organic matter from surface water and wastewater effluent. Ecotoxicol. Environ. Saf. 61, 337-344.

Saunders, F.M., Dick, R.I., 1981. Effect of mean-cell residence time on organic composition of activated sludge effluents. J. Water Pollut. Control Fed. 201-215.

Schwartz, M.L., Curtis, P.J., Playle, R.C., 2004. Influence of natural organic matter source on acute copper, lead, and cadmium toxicity to rainbow trout (Oncorhynchus mykiss). Environ. Toxicol. Chem. 23 (12), 2889-2899.

Sedlak, D.L., Deeb, R.A., Hawley, E.L., Mitch, W.A., Durbin, T.D., Mowbray, S., Carr, S., 2005. Sources and fate of nitrosodimethylamine and its precursors in municipal wastewater treatment plants. Water Environ. Res. 77 (1), 32-39.

Serkiz, S.M., Perdue, E.M., 1990. Isolation of dissolved organic matter from the Suwannee River using reverse osmosis. Water Res. 24 (7), 911-916.

Sharif, F., Wang, J., Westerhoff, P., 2012. Transformation in bulk and trace organics during ozonation of wastewater. Ozone Sci. Eng. 34, 26-31.

Shenker, M., Harush, D., Ben-Ari, J., Chefetz, B., 2011. Uptake of carbamazepine by cucumber plants - a case study related to irrigation with reclaimed wastewater. Chemosphere 82 (6), 905-910.

Shon, H., Vigneswaran, S., Ngo, H., Kim, D., Park, N., Jang, N., Kim, I.S., 2003. Characterization of effluent organic matter (EfOM) of fouled nanofilter (NF) membranes. In: Proceedings of the International Membrane Science and Technology (IMSTEC), Sydney, Australia.

Shon, H., Vigneswaran, S., Kim, I.S., Cho, J., Ngo, H., 2004. The effect of pretreatment to ultrafiltration of biologically treated sewage effluent: a detailed effluent organic matter (EfOM) characterization. Water Res. 38 (7), 1933-1939.

Shon, H., Vigneswaran, S., Ngo, H., Kim, J., 2005. Chemical coupling of photocatalysis with flocculation and adsorption in the removal of organic matter. Water Res. 39 (12), 2549-2558.

Shon, H., Vigneswaran, S., Snyder, S., 2006a. Effluent organic matter (EfOM) in wastewater: constituents, effects, and treatment. Crit. Rev. Environ. Sci. Technol. 36 (4), 327-374.

Shon, H., Vigneswaran, S., Ngo, H., Johnston, A., Kim, I.S., Cho, J., 2006b. Performance of flocculation and adsorption pretreatments to ultrafiltration of biologically treated sewage effluent: the effect of seasonal variations. Sep. Sci. Technol. 41 (16), 3585-3596.

Shon, H.K., Vigneswaran, S., Kim, I.S., Cho, J., Ngo, H.H., 2006c. Fouling of ultrafiltration membrane by effluent organic matter: a detailed characterization using different organic fractions in wastewater. J. Membr. Sci. 278, 232-238.

Shon, H.K., Vigneswaran, S., Kim, J.H., Ngo, H.H., 2007. Application of hybrid photocatalysis systems coupled with flocculation and adsorption to biologically treated sewage effluent for organic removal. Korean J. Chem. Eng. 24 (4), 618-623.

Singer, P.C., Bilyk, K., 2002. Enhanced coagulation using a magnetic ion exchange resin. Water Res. 36 (16), 4009-4022.
Sirivedhin, T., Gray, K.A., 2005. Part I. Identifying anthropogenic markers in surface waters influenced by treated effluents: a tool in potable water reuse. Water Res. 39, 1154-1164.

Slaveykova, V.I., Wilkinson, K.J., Ceresa, A., Pretsch, E., 2003. Role of fulvic acid on lead bioaccumulation by Chlorella kesslerii. Environ. Sci. Technol. 37 (6), 1114-1121.

Souza, B.Z., Dantas, R.F., Cruz, A., Sans, C., Esplugas, S., Dezotti, M., 2014. Photochemical oxidation of municipal secondary effluents at low $\mathrm{H}_{2} \mathrm{O}_{2}$ dosage: study of hydroxyl radical scavenging and process performance. Chem. Eng. J. 237, 268-276.

Stalter, D., Magdeburg, A., Oehlmann, J., 2010. Comparative toxicity assessment of ozone and activated carbon treated sewage effluents using an in vivo test battery. Water Res. 44, 2610-2620.

Steinle-Darling, E., Zedda, M., Plumlee, M.H., Ridgway, H.F., Reinhard, M., 2007. Evaluating the impacts of membrane type, coating, fouling, chemical properties and water chemistry on reverse osmosis rejection of seven nitrosoalklyamines, including NDMA. Water Res. 47, 3959-3967.

Sun, Y.X., Wu, Q.Y., Hu, H.Y., Tian, J., 2009. Effect of bromide on the formation of disinfection by-products during wastewater chlorination. Water Res. 43, 2391-2398.

Sutton, R., Sposito, G., 2005. Molecular structure in soil humic substances: the new view. Environ. Sci. Technol. 39 (23), 9009-9015.

Świetlik, J., Sikorska, E., 2004. Application of fluorescence spectroscopy in the studies of natural organic matter fractions reactivity with chlorine dioxide and ozone. Water Res. 38 (17), 3791-3799.

Świetlik, J., Dąbrowska, A., Raczyk-Stanisławiak, U., Nawrocki, J., 2004. Reactivity of natural organic matter fractions with chlorine dioxide and ozone. Water Res. 38 (3), 547-558.

Tan, Y., Kilduff, J.E., 2007. Factors affecting selectivity during dissolved organic matter removal by anion-exchange resins. Water Res. 41 (18), 4211-4221.

Tchobanoglous, G., Leverenz, H.L., Nellor, M.H., Crook, J., 2011. Direct Potable Reuse: a Path Forward. WateReuse Research Foundation. WateReuse California, Alexandria, VA. http:// www.watereuse.org/product/direct-potable-reuse-pathforward.

Tercero Espinoza, L.A., Frimmel, F.H., 2009. A simple simulation of the degradation of natural organic matter in homogeneous and heterogeneous advanced oxidation processes. Water Res. 43 (16), 3902-3909.

The White House, 2014. National Strategy for Combating Antibiotic-resistant Bacteria. http://www.whitehouse.gov/ sites/default/files/docs/carb_national_strategy.pdf.

Thomson, J., Parkinson, A., Roddick, F.A., 2004. Depolymerization of chromophoric natural organic matter. Environ. Sci. Technol. 38 (12), 3360-3369.

Thurman, E.M., 1985. Amount of organic carbon in natural waters. In: Organic Geochemistry of Natural Waters. Developments in Biogeochemistry, vol. 2. Springer, pp. 7-65.

Timofeyev, M.A., Shatilina, Z.M., Kolesnichenko, A.V., Bedulina, D.S., Kolesnichenko, V.V., Pflugmacher, S., Steinberg, C.E., 2006. Natural organic matter (NOM) induces oxidative stress in freshwater amphipods Gammarus lacustris Sars and Gammarus tigrinus (Sexton). Sci. Total Environ. 366 (2), 673-681.

Tizaoui, C., Grima, N., Hilal, N., 2011. Degradation of the antimicrobial triclocarban (TCC) with ozone. Chem. Eng. Process. Process Intensif. 50 (7), 637-643.

Tran, H., Scott, J., Chiang, K., Amal, R., 2006. Clarifying the role of silver deposits on titania for the photocatalytic mineralisation 
of organic compounds. J. Photochem. Photobiol. A Chem. 183 (1), $41-52$.

Trovó, A.G., Melo, S.A.S., Nogueira, R.F.P., 2008. Photodegradation of the pharmaceuticals amoxicillin, bezafibrate and paracetamol by the photo-Fenton process - application to sewage treatment plant effluent. J. Photochem. Photobiol. A Chem. 198 (2), 215-220.

Umar, M., Roddick, F.A., Fana, L., Autin, O., Jefferson, B., 2015. Treatment of municipal wastewater reverse osmosis concentrate using UVC-LED/ $\mathrm{H}_{2} \mathrm{O}_{2}$ with and without coagulation pre-treatment. Chem. Eng. J. 260, 649-656.

Urai, M., Kasuga, I., Kurisu, F., Furumai, H., 2014. Molecular characterization of dissolved organic matter in various urban water resources using Orbitrap Fourier transform mass spectrometry. Water Sci. Technol. Water Supply 14, 547-553.

USEPA, 1991. Technical Support Document for Water Qualitybased Toxics Control. EPA/505/2-90001.

USEPA, 2004. Guidelines for Water Reuse. EPA/625/R-04/108.

USEPA, 2006. National primary drinking water regulations: stage 2 disinfectants and disinfection by products rule: final rule. Fed. Regist. 71 (2).

Uyguner, C., Bekbolet, M., Selcuk, H., 2007. A comparative approach to the application of a physico-chemical and advanced oxidation combined system to natural water samples. Sep. Sci. Technol. 42 (7), 1405-1419.

Uyguner-Demirel, C., Bekbolet, M., 2011. Significance of analytical parameters for the understanding of natural organic matter in relation to photocatalytic oxidation. Chemosphere 84 (8), 1009-1031.

Vasquez, M., Fatta-Kassinos, D., 2013. Is the evaluation of "traditional" physicochemical parameters sufficient to explain the potential toxicity of the treated wastewater at sewage treatment plants? Environ. Sci. Pollut. Res. 20 (6), 3516-3528.

Vigneault, B., Percot, A., Lafleur, M., Campbell, P.G., 2000 Permeability changes in model and phytoplankton membranes in the presence of aquatic humic substances. Environ. Sci. Technol. 34 (18), 3907-3913.

Von Gunten, U., 2003. Ozonation of drinking water: part I. Oxidation kinetics and product formation. Water Res. 37 (7), 1443-1467.

Wang, J., Li, H., Li, A., Shuang, C., Zhou, Q., 2014. Dissolved organic matter removal by magnetic anion exchange resin and released ion elimination by electrolysis. Chem. Eng. J. 253, 237-242.

Watkinson, A., Murby, E., Kolpin, D., Costanzo, S., 2009. The occurrence of antibiotics in an urban watershed: from wastewater to drinking water. Sci. Total Environ. 407 (8), 2711-2723.

Weber, S., Khan, S., Hollender, J., 2006. Human risk assessment of organic contaminants in reclaimed wastewater used for irrigation. Desalination 187 (1), 53-64.

Weishaar, J.L., Aiken, G.R., Bergamaschi, B.A., Fram, M.S., Fujii, R., Mopper, K., 2003. Evaluation of specific ultraviolet absorbance as an indicator of the chemical composition and reactivity of dissolved organic carbon. Environ. Sci. Technol. 37 (20), $4702-4708$.

Wert, E.C., Rosario-Ortiz, F.L., Drury, D.D., Snyder, S.A., 2007. Formation of oxidation byproducts from ozonation of wastewater. Water Res. 41, 1481-1490.

Westerhoff, P., Aiken, G., Amy, G., Debroux, J., 1999. Relationships between the structure of natural organic matter and its reactivity towards molecular ozone and hydroxyl radicals. Water Res. 33 (10), 2265-2276.

Westerhoff, P., Mezyk, S.P., Cooper, W.J., Minakata, D., 2007. Electron pulse radiolysis determination of hydroxyl radical rate constants with Suwannee River fulvic acid and other dissolved organic matter isolates. Environ. Sci. Technol. 41 (13), 4640-4646.
WHO, 2006. WHO Guidelines for the Safe use of Wastewater, Excreta and Greywater. In: Wastewater Use in Agriculture, vol. II. World Health Organization, p. 222.

WHO, 2008. Guidelines for Drinking-Water Quality, third ed.

WHO, 2014. Antimicrobial Resistance Global Report on Surveillance. http://apps.who.int/iris/bitstream/10665/112642/ 1/9789241564748_eng.pdf?ua=1.

Wiszniowski, J., Robert, D., Surmacz-Gorska, J., Miksch, K., Weber, J., 2002. Photocatalytic decomposition of humic acids on $\mathrm{TiO}_{2}$ : part I: discussion of adsorption and mechanism. J. Photochem. Photobiol. A: Chem. 152 (1), 267-273.

Wood, C.M., Matsuo, A.Y., Wilson, R.W., Gonzalez, R., Patrick, M.L., Playle, R.C., Val, A.L., 2003. Protection by natural blackwater against disturbances in ion fluxes caused by low $\mathrm{pH}$ exposure in freshwater stingrays endemic to the Rio Negro. Physiol. Biochem. Zool. 76 (1), 12-27.

Worms, I.A., Traber, J., Kistler, D., Sigg, L., Slaveykova, V.I., 2010. Uptake of $\mathrm{Cd}$ (II) and $\mathrm{Pb}$ (II) by microalgae in presence of colloidal organic matter from wastewater treatment plant effluents. Environ. Pollut. 158 (2), 369-374.

Wu, F., Evans, R., Dillon, P., 2003. Separation and characterization of NOM by high-performance liquid chromatography and online three-dimensional excitation emission matrix fluorescence detection. Environ. Sci. Technol. 37 (16), 3687-3693.

Wu, X., Ernst, F., Conkle, J.L., Gan, J., 2013. Comparative uptake and translocation of pharmaceutical and personal care products (PPCPs) by common vegetables. Environ. Int. 60, 15-22. J. Hazard. Mater. 273, 280-286.

Wu, Q.Y., Tang, X., Huang, H., Li, Y., Hu, H.Y., Ding, Y.N., Shao, Y.R., 2014. Antiestrogenic activity and related disinfection by-product formation induced by bromide during chlorine disinfection of sewage secondary effluent. J. Hazard. Mater. 273, 280-286.

Xu, B., Gao, N.Y., Sun, X.F., Xia, S.J., Simonnot, M.O., Causserand, C., Rui, M., Wu, H.H., 2007. Characteristics of organic material in Huangpu River and treatability with the O3-BAC process. Sep. Purif. Technol. 57, 348-355.

Yang, X., Shang, C., Huang, J.C., 2005. DBP formation in breakpoint chlorination of wastewater. Water Res. 39, $4755-4767$.

Yang, X.L., Song, H.L., Chen, M., Cheng, B., 2011. Characterizing membrane foulants in MBR with addition of polyferric chloride to enhance phosphorus removal. Bioresour. Technol. 102, 9490-9496.

Yu, H., Qua, F., Sun, L., Liang, H., Han, Z., Chang, H., Shao, S., Li, G., 2015. Relationship between soluble microbial products (SMP) and effluent organic matter (EfOM): characterized by fluorescence excitation emission matrix coupled with parallel factor analysis. Chemosphere 121, 101-109.

Zhang, R., Vigneswaran, S., Ngo, H.H., Nguyen, H., 2006. Magnetic ion exchange (MIEX ${ }^{\mathbb{R}}$ ) resin as a pre-treatment to a submerged membrane system in the treatment of biologically treated wastewater. Desalination 192 (1), 296-302.

Zhang, R., Vigneswaran, S., Ngo, H., Nguyen, H., 2007. A submerged membrane hybrid system coupled with magnetic ion exchange (MIEX ${ }^{\circledR}$ ) and flocculation in wastewater treatment. Desalination 216, 325-333.

Zhang, X., Zhang, T., Fang, H.H., 2009. Antibiotic resistance genes in water environment. Appl. Microbiol. Biotechnol. 82 (3), 397-414.

Zhang, X., Li, F., Zhao, X., 2012. Application of a magnetic resin $\left(M^{\circledR} X^{\circledR}\right)$ in wastewater reclamation for managed aquifer recharge. Water Air Soil Pollut. 223, 4687-4694.

Zheng, X., Khan, M.T., Croué, J.P., 2014. Contribution of effluent organic matter (EfOM) to ultrafiltration (UF) membrane fouling: Isolation, characterization, and fouling effect of EfOM fractions. Water Res. 65, 414-424. 
Zumstein, J., Buffle, J., 1989. Circulation of pedogenic and aquagenic organic matter in an eutrophic lake. Water Res. 23 (2), 229-239.

2000/60/EC, Water Framework Directive of the European Parliament and of the Council of 23 October 2000 establishing a framework for Community action in the field of water policy
(OJ L 327, 22.12.2000, p. 1). http://eurlex.europa.eu/LexUriServ/ LexUriServ.do?uri=CELEX:02000L0060-20090113:EN:NOT. 91/271/EEC, Council Directive concerning urban wastewater treatment. http://eur-lex.europa.eu/legal-content/EN/TXT/ $\mathrm{PDF}$ /?uri=CELEX:31991L0271\&from $=\mathrm{EN}$. 